\title{
SPATIAL AND TEMPORAL PATTERNS OF OGALLALA FORMATION DEPOSITION REVEALED BY U-PB ZIRCON GEOCHRONOLOGY
}

BY

\section{JASON ANDREW HALLMAN}

Submitted to the graduate degree program in Geology and the Graduate Faculty of the University of Kansas in partial fulfillment of the requirements for the degree of Master of Science.

Co-Chairperson Andreas Möller

Co-Chairperson Noah M. McLean

$\overline{\text { Greg A. Ludvigson }}$

Mary C. Hill

Date Defended: June 28, 2016 
The Thesis Committee for JASON ANDREW HALLMAN

certifies that this is the approved version of the following thesis:

\section{SPATIAL AND TEMPORAL PATTERNS OF OGALLALA FORMATION DEPOSITION REVEALED BY U-PB ZIRCON GEOCHRONOLOGY}

Co-Chairperson Andreas Möller

Co-Chairperson Noah M. McLean

Date approved: June 28, 2016 


\section{ABSTRACT}

Difficulties in correlation within continental clastic basins arise from the common shortage of reliable marker beds, which limits characterization of geological relationships. In the High Plains of the central United States, an improved understanding of the stratigraphic architecture of the terrestrial Ogallala Formation can be used to improve management of depleted groundwater resources, illuminate the causes of fluvial aggradation, enhance the western US climatic record, and strengthen the temporal precision of the North American Land Mammal Ages. Such relationships can be derived from chronostratigraphic information provided by abundant, dateable, volcanogenic zircon in volcanic ashes and fluvial beds, which provide the first highprecision (ca. 1-5\% uncertainty) radioisotopic dates for the Ogallala Formation. These zirconbearing ashes appear to have travelled $\sim 1350 \mathrm{~km}$ from their interpreted sources within the Bruneau-Jarbidge and Twin Falls volcanic centers in Idaho, suggesting that volcanogenic zircon has the previously unappreciated potential to time-stamp terrestrial surfaces at great distances from contemporaneous magmatic centers. Volcanic ash depositional ages are consistent with fluvial maximum depositional ages, indicating that deposition of common lithologies within the Ogallala Formation, including sands, paleosols, and volcanic ashes can be reliably dated with modern, high-precision techniques. Zircon U-Pb LA-ICP-MS results suggest diachronous aggradation of the Ogallala Formation in Kansas, particularly deposition of an inferred Norton lobe in northern Kansas that initiated prior to $\sim 12.5 \mathrm{Ma}$ and aggraded to near-modern levels by 11.7 Ma, measurably earlier than the 8-9.5 Ma deposition of an inferred Ellis lobe over a bedrock high in central Kansas. The observed diachronous relationships predict aquifer anisotropy that could inform efforts to develop numerical groundwater models designed to forecast aquifer response to different conservation strategies. 


\section{ACKNOWLEDGEMENTS}

This work was initiated and supported by Dr. Greg Ludvigson and Dr. Jon Smith, who graciously encouraged this foray into High Plains geology. The mentorship of Dr. Noah McLean and Dr. Andreas Möller was expert, patient, and tireless, exceeding what could be expected from any adviser. Much time and energy was devoted to the improvement of this work by Dr. J. Douglas Walker and Dr. Joe Andrew, despite many frustrations and setbacks. Insightful comments and critiques from Dr. Mary C. Hill steered this project in a more realistic and fruitful direction, and discussions with Dr. Michael Blum improved the quality of this work. Thanks are owed to Ben Campanaro, Soroush Rezvanbehbahani, Maggie Graham, Ty Tenpenny, Jeff Oalmann, Tyson Berndt, Josh Feldman, Wayne Dickerson, and members of IGL who provided invaluable assistance, training, and guidance. Analytical techniques proposed in the Boise State University IGL Labshare improved the efficiency and success rate of laboratory procedures. Special thanks are owed to Brian Sitek for splitting fieldwork and for sharing unpublished information, as well as to the Calvert Corporation and Mr. Taylor G. Bemis for granting property access. Partial support for this project comes from the University of Kansas, the Kansas Geological Foundation, the Geological Society of America, and the SIPES Foundation. Logistical and financial support from the KGS was made possible by a National Science Foundation grant to Jon Smith and a USGS STATEMAP grant to the KGS. 


\section{TABLE OF CONTENTS}

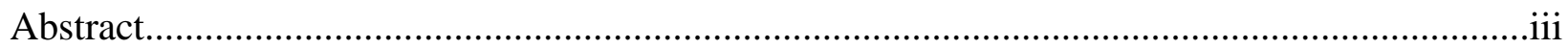

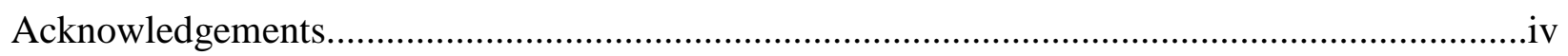

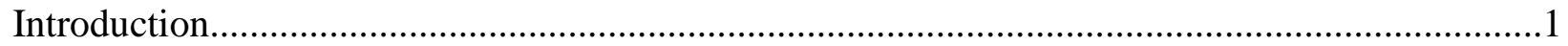

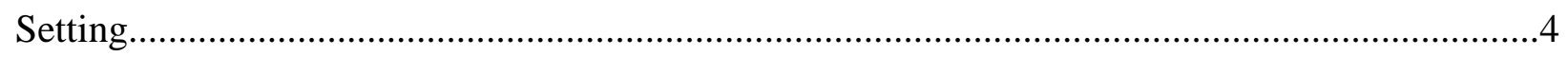

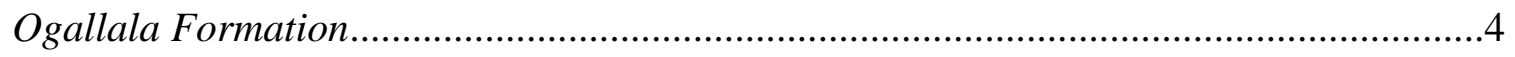

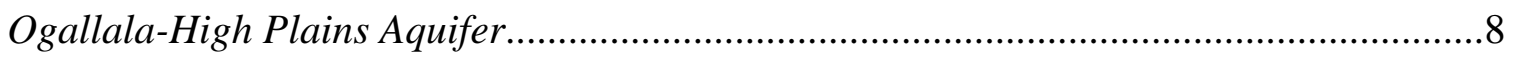

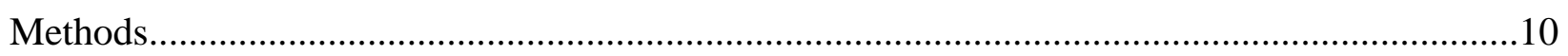

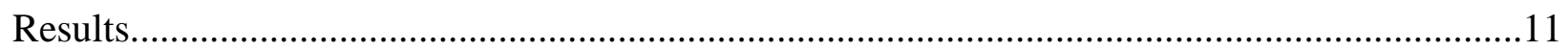

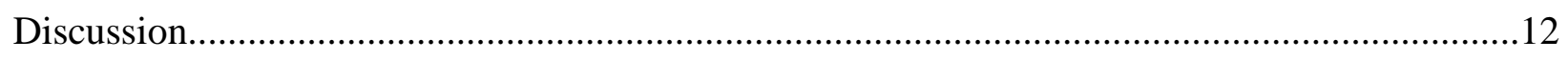

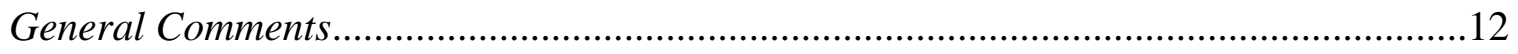

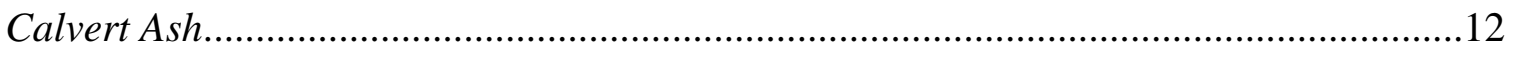

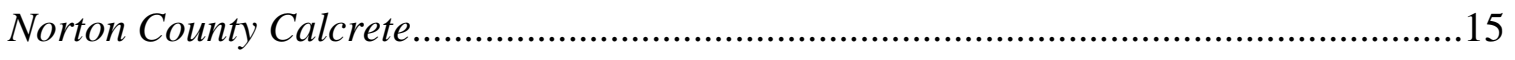

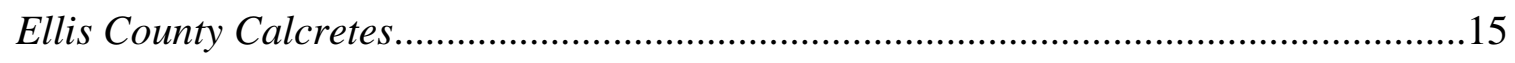

Complications in Determining Provenance .........................................................16

Ash Depositional Environment ...................................................................... 17

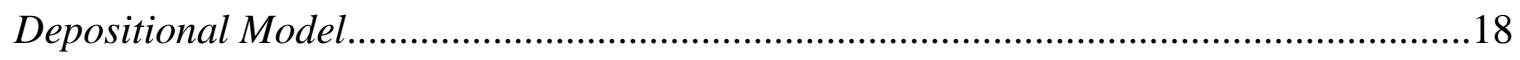

Significance of Results to the Ogallala-High Plains Aquifer.........................................22

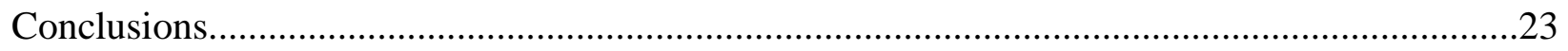

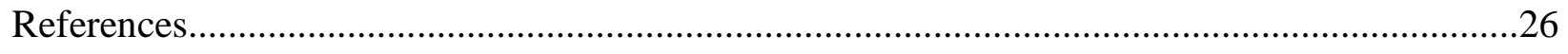

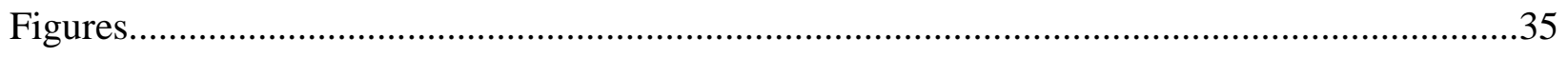

Fig. 1. Global Distribution of Holocene Continental Basins and Volcanoes....................35

Fig. 2. Kansas Ogallala Fm. Distribution and Contact Relationships.............................36 
Fig. 3. Kernel Density Plots

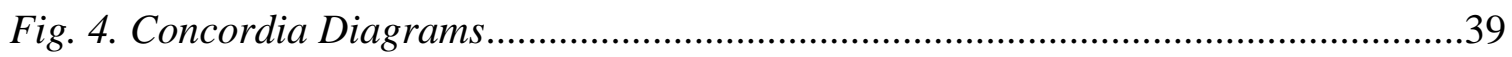

Fig. 5. Sample Localities Placed in Spatial and Temporal Context.................................41

Fig. 6. Inferred Distribution of DFS Lobes in the High Plains........................................42

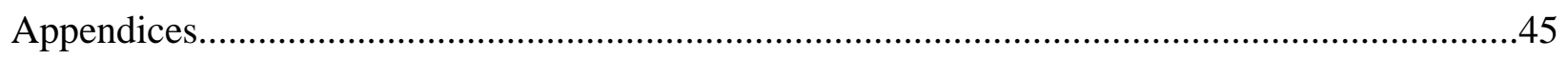

Appendix A: Annotated Outcrop Photographs .........................................................45

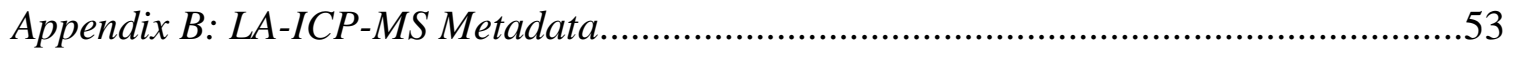

Appendix C: LA-ICP-MS Quality Control and Validation..............................................55

Appendix D: LA-ICP-MS U-Pb Zircon Data...........................................................56 


\section{INTRODUCTION}

Depositional models of fluvial clastic basins are difficult to develop and often incomplete because correlation on a basin-wide scale is barred by frequent irregular lateral and vertical facies changes, common secondary alteration that obscures original depositional features, and indistinguishable lithologies coupled with a shortage and limited extent of distinctive marker beds (Swinehart, 1974; North and Prosser, 1993; Sweet, 1999; Newell, 2001). The lenticular, indistinct units and frequent absence of viable marker beds often hinders detailed stratigraphic investigations in these basins, which is critical to the understanding of depositional causes and timing, stratigraphic context of fossil assemblages, and the three-dimensional extent of contained mineral or water resources. If understanding of a basin's lithostratigraphy is insufficient for analysis of its stratigraphic architecture, then other tools are needed to supply information about depositional processes and timescales.

Investigating the absolute depositional timing of continental deposits might thus be the best means of unravelling the stratigraphic architecture of basins that preserve dateable material. Ashfall zircon is commonly used to measure the depositional age of marine sequences (e.g. Bowring and Schmitz, 2003; Mundil et al., 2004; Furin et al., 2006; Burgess et al., 2014), but because continental basins are often high energy, alternately erosional and depositional environments vulnerable to weathering and alteration, dateable materials like volcanic ash may be locally absent or difficult to recognize. The chronological record of continental basins has therefore enjoyed less study than the marine record, despite the potential existence of dateable and stratigraphically useful material.

Here we suggest that the dating potential for continental clastic basins based on ashfall deposits may be greater than was previously recognized. Silicic volcanic centers yield frequent 
eruptions of volcanic ash, of which zircon is a common component. Volcanic ash beds are common in Miocene fluvial sequences of the High Plains of the central United States (Carey et al., 1952; Izett and Wilcox, 1982; Ludvigson et al., 2009), making this area a rich testing ground for dating methods of continental strata. The spatial correlation (Fig. 1) between modern volcanic centers and large, fluvial clastic basins termed distributive fluvial systems (DFSs) by Weissmann et al. (2010) indicates that many of these terrestrial basins might also host similarly dateable deposits. Continental clastic basins beyond Miocene or Holocene age may also commonly contain volcanic material.

Volcanic ash can remain aloft in the atmosphere over distances of thousands of kilometers (Rose et al., 2003), yet little research has been devoted to the heavy mineral content of distal volcanic ashes. The density and geometry of zircon crystals implies that long-distance airborne travel should be aerodynamically unfavorable. However, volcanogenic zircon interpreted as distal ash fallout has been recognized in marine sequences up to a few thousand kilometers from its presumed vent (e.g. Santos et al., 2006; Rasmussen and Fletcher, 2010). Even basins separated by thousands of kilometers from very large silicic eruptions may thus preserve significant volumes of volcanic ash. If these ashes include cogenetic, dateable zircons contemporaneous with deposition, then the zircons can be used to accurately and precisely date associated deposits.

The Ogallala Formation is a broad apron of fluvial and aeolian sediments shed from the Rocky Mountains onto the Great Plains in the mid-late Miocene. It defines the modern High Plains, a broad, mostly flat expanse of semi-arid grassland stretching from New Mexico and Texas in the south to Wyoming and South Dakota in the north (Fenneman, 1917). Its inclusion of lenses of zircon-bearing volcanic ash presumably from magmatic centers in the western United 
States makes it ideally suited to the exploration of dating methods for continental strata. These units contain abundant, contemporaneous zircon, yet none have been previously analyzed with modern, high-precision techniques (Ludvigson et al., 2009). We apply laser ablation inductively coupled plasma mass spectrometry (LA-ICP-MS) U-Pb zircon geochronology with single-grain uncertainties ca. 5-10\% to date common Ogallala Formation lithologies.

The ubiquitous presence of young, evidently syndepositional volcanogenic zircon in common Ogallala Formation deposits like sand, pedogenic calcretes, and altered and unaltered ash beds indicates that accurate depositional or maximum depositional ages can likely be measured within the $\sim 5 \%$ analytical uncertainty of single analyses. High-precision radioisotopic dating of the Ogallala Formation and comparison with dated tectonic and marine isotopic events may help to illuminate the causes of Ogallala Formation aggradation, enhance the western US climatic record, and strengthen the temporal precision of the North American Land Mammal Ages (NALMAs). In this work, it is also shown that temporal resolution of LA-ICP-MS dating is adequate for the evaluation of two models of Ogallala Formation aggradation: deposition as an alluvial plain (Johnson, 1901; Smith, 1940; Frye and Leonard, 1964), or aggradation as diachronous, avulsing lobes (Seni, 1980; Skinner and Johnson, 1984; Chapin, 2008; Galloway et al., 2011; Harlow, 2013), termed distributive fluvial systems by Weissmann et al. (2010). These models predict different stratigraphic architectures and three-dimensional arrangements of high and low hydraulic conductivity units, so this information is prerequisite to the planned development by the Kansas Geological Survey (KGS) of more accurate groundwater flow models designed to assess the water resources of the rapidly declining Ogallala-High Plains aquifer. 


\section{SETTING}

\section{Ogallala Formation}

The $350,000 \mathrm{~km}^{2}$ (Gutentag et al., 1984) Ogallala Formation is a sequence of gravels, sands, and clays of fluvial and aeolian origin (Darton, 1903; Hawley et al., 1976) shed from the Rocky Mountains in the mid-late Miocene (Frye et al., 1956; Ludvigson et al., 2009). Included within the dominant fluvial deposits are pedogenic calcretes and lenses of volcanic ash (Darton, 1903; Swineford et al., 1958), the latter of which may comprise as much as $3 \%$ volumetrically of the lower parts of the formation (Swineford et al., 1955). The Ogallala Formation is typically mantled with Quaternary loess and other aeolian sediments (Soller and Reheis, 2004).

Deposition of the Ogallala Formation progressed as a series of fluvial deposits that first filled incised bedrock valleys (Seni, 1980; Swinehart et al., 1985; Gustavson and Winkler, 1988) before overtopping them, eventually forming a broad sheet that may have stretched from the erosional surface of the Rocky Mountains to the Flint Hills topographic barrier in eastern Kansas (Frye et al., 1956; Zeller, 1968). In northwestern Kansas, the Ogallala Formation fills paleovalleys incised into Cretaceous rocks of the Western Interior Seaway (Frye and Leonard, 1949; Neuhauser and Pool, 1988), resulting in up to $100 \mathrm{~m}$ of basal relief (Heller et al., 2003). Fluvial valley fill conglomerates and sands are interpreted as longitudinal bar channel deposits from braided streams due to common fining-upward sequences, shallow, wide channels, and a scarcity of overbank deposits (Goodwin and Diffendal, 1987). These streams were probably high

energy, braided, and ephemeral, with deposition punctuated by periods of landscape stability and aeolian processes (Gustavson and Winkler, 1988; Fielding et al., 2007; Harlow, 2013). Deposition of the Ogallala Formation south of the Canadian River in Texas may have diverged from the dominant-fluvial aggradation farther north (Holliday, 1991). Following fluvial valley 
aggradation, a sheet of aeolian-dominated sediments may have blanketed valley fills and interfluves in Texas (Gustavson and Winkler, 1988). Pliocene to modern incision continues to erode the Ogallala Formation from stream valleys and along its margin, including erosion from within $\sim 150 \mathrm{~km}$ of the Rocky Mountain front in Colorado and New Mexico (Heller et al., 1988).

Ogallala aggradation has been attributed to late Cenozoic uplift of the Rocky Mountains by many authors (Eaton, 1987; Heller et al., 1988; Wayne et al., 1991; Heller et al., 2003) due to evidence for several hundred meters of regional differential uplift centered under the Rocky Mountains (Trimble, 1980; Leonard, 2002; McMillan et al., 2002; McMillan et al., 2006; Riihimaki et al., 2007; Galloway et al., 2011; Duller et al., 2012). However, this welldocumented uplift episode is probably contemporaneous with Pliocene incision in the High Plains, rather than increased deposition of highland-sourced clasts (Leonard, 2002; Galloway et al., 2011; Duller et al., 2012). A middle Miocene global increase in sedimentation that accelerated during the Pliocene (Molnar, 2004), as well as late-Cenozoic conglomerates adjacent to mountain ranges worldwide (Molnar and England, 1990) are attributed to climate change rather than globally-synchronous tectonic upheaval for which there is no evidence (Molnar and England, 1990; Molnar, 2004). Following this line of reasoning, Ogallala aggradation has been attributed to a mid-late Miocene period of aridity that both reduced vegetative cover in the Rocky Mountains and decreased stream capacity in the Great Plains, causing increased erosion in the highlands and deposition in the plains (Chapin, 2008; Galloway et al., 2011). After Ogallala deposition, Pliocene uplift and incision was likely facilitated by a climatically induced transition to increased streamflow (Wobus et al., 2010) from initiation of the North American monsoon 5$7 \mathrm{Ma}$ (Oskin and Stock, 2003; Chapin, 2008; Galloway et al., 2011). Efforts to discern the relative importance of tectonics and climate on Ogallala deposition and erosion may be informed 
by high-precision radioisotopic dating and comparison with dated tectonic and marine isotopic events (Harlow, 2013).

The Ogallala Formation preserves a high-fidelity record of the climatic, tectonic, and biological records of the Neogene interior of North America, yet understanding of the interconnections between these diverse data has been impeded by its complex and alterationprone stratigraphy. Lithologic correlation of clastic units has been hampered by variable degrees of pedogenic calcrete alteration that causes equivalent units to appear dissimilar and obscures original depositional and lithological characteristics (Izett and Wilcox, 1982; Ludvigson et al., 2009; Kreitzer, 2011; Smith and Ludvigson, 2011). Complex fluvial depositional patterns mean that sediments fail to follow a consistent stratigraphic order (Swinehart, 1974), and distinctive units tend to be too limited in extent for use as marker beds (Frye et al., 1956). A further obstacle to lithologic correlation is imposed by the low relief topography of the High Plains, which minimizes the abundance and stratigraphic thickness of surface exposures.

The uncertain lithostratigraphy of the Ogallala Formation led Frye et al. (1956) to conclude that members lack sufficient contrast with neighboring units to be mapped or correlated as rock-stratigraphic units. Correlation must therefore be undertaken chronologically. Most geochronologic study of the Ogallala Formation has focused on the fossil record (e.g. Thomasson, 1979; Bennett, 1983; Thomasson, 1990; Zakrzewski, 1990; Bartley, 2005; Ludvigson et al., 2009), though a handful of attempts have been made via chemical fingerprinting of Ogallala Formation ashes and correlation to dated volcanic eruptions (Perkins, 1998; David, 2006; Ludvigson et al., 2009), or radioisotopic dating of volcanic glass by the K-Ar (Thomasson, 1979) or glass fission-track methods (Boellstorff, 1976; Naeser et al., 1980; Bennett, 1983; Skinner and Johnson, 1984). The most precise and likely most accurate 
depositional age yet assigned to any part of the Ogallala Formation comes from a single-grain LA-ICP-MS U-Pb zircon date of $11.35 \pm 0.44 \mathrm{Ma}$ (Fig. 2) for an ash from Landon Draw in Scott County, KS (personal communication from analyst Brian Sitek, 2014). Existing paleontological, chemical correlation, and radioisotopic data are broadly consistent with Ogallala Formation deposition from the middle Miocene to earliest Pliocene, yet too low in precision to make detailed geological interpretations about depositional processes and timescales. Identification of syndepositional zircons from numerous potentially zircon-bearing volcanic ash beds, fluvial units, and paleosols in the Ogallala Formation provides high-precision (ca. 1-5\% uncertainty) dates that facilitate these goals.

The presence of dateable material in the Ogallala Formation, along with its complex and diachronous depositional history, makes it an excellent location to test the use of radioisotopic dating methods for geologic characterization of these continental strata. Volcanic ash beds, when present and recognizable, provide accurate depositional ages that can be used to assess the accuracy of detrital maximum depositional ages from adjacent units that potentially contain pyroclastic zircon. Paleosols are common in continental basins (Kraus, 1999) including the Ogallala Formation, where they are most often recognized as pedogenic calcretes formed as a result of the dry grassland climate of the Great Plains in the late Miocene (Wayne et al., 1991). Paleosols represent periods of landscape stability (Birkeland, 1999) and record a nearly uninterrupted record of atmospheric deposition (Sheldon and Tabor, 2009; Dunne, 2013). They are thus likely to capture and preserve the chemically resilient fraction of volcanic ash that includes zircon via bioturbation and piping through roots and desiccation cracks (Smith et al., 2014; Turner et al., 2015; Smith et al., 2016). These units could contain reliable temporal 
information that can be used to construct detailed depositional and landscape evolution histories for continental basins.

Sedimentary horizons from the Ogallala Formation were selected based on their ashbearing potential and sampled from sites in Norton and Ellis counties in northwestern Kansas (Fig. 2). Sampled outcrops (Appendix A) include vitric ashes (Figs. 12, 13), calcretes (Figs. $7,8,9,10,14$ ), and a bentonite (Fig. 11), all of which yield pyroclastic zircon. The Calvert volcanic ash mine of Norton County (Carey et al., 1952) exposes a bed of vitric ash that reaches $\sim 8 \mathrm{~m}$ in thickness (Potter, 1991). Exposed in the active mine face is a meter-scale bed of pure ash (Fig. 13) that grades upwards into very fine sand and 5-10 m of marl, soil (Potter, 1991), and two rhizolith-bearing meter-scale bentonite lenses (Fig. 11), all of which is overlain by loess. A calcrete from Norton County (Fig. 14) was also sampled from a roadcut near the town of Almena. Ashes from the Calvert volcanic ash mine were sampled from an elevation of $\sim 685 \mathrm{~m}$, and the Norton County calcrete was sampled from an elevation of $\sim 680 \mathrm{~m}$. In both areas, the depth to pre-Cenozoic bedrock is $\sim 35-45 \mathrm{~m}$ (Fig. 2). In Ellis County, three pedogenic calcrete sequences that were tentatively correlated to one another on the basis of plant fossils (Thomasson, 1979) contain abundant rounded quartz and lithic clasts (Figs. 7, 8, 9, 10) and were sampled from elevations of $\sim 670-680 \mathrm{~m}$, with depth to pre-Cenozoic bedrock ranging from $\sim 5$ $15 \mathrm{~m}$. Geochronology coupled with bedrock and outcrop elevation data provides threedimensional architectural information that helps to illuminate the sequence and timing of aggradation at the formation scale.

\section{Ogallala-High Plains Aquifer}

The Ogallala Formation and hydrologically connected Quaternary units host the OgallalaHigh Plains aquifer, one of the world's largest and most agriculturally important freshwater 
aquifers (Smith et al., 2014), and the primary domestic and irrigation water source for the High Plains (Frye and Leonard, 1949; Seni, 1980; Gutentag et al., 1984; Kreitzer, 2011; Harlow, 2013; Steward et al., 2013; Smith et al., 2014; Steward and Allen, 2016). Increasing withdrawals for irrigation and stress from climate change continue to diminish its water resources at an accelerating pace (Gutentag et al., 1984; Kustu et al., 2010). In many parts of the aquifer, irrigation withdrawals far exceed recharge, leading to drawdowns (Gutentag et al., 1984; McGuire, 2009) severe enough to warrant concerns about the long-term sustainability of High Plains agriculture (Dennehy et al., 2002; Macfarlane, 2009). The threat posed by the depletion of this critical resource necessitates development of groundwater management strategies and numerical models designed to predict aquifer response to those strategies (Harlow, 2013; Smith et al., 2014; Butler et al., 2016).

Groundwater recharge and flow modeling requires detailed information on aquifer thickness, porosity, grain size, sorting, and bedrock geology (Seni, 1980; Koltermann and Gorelick, 1996; Fogg et al., 1998). This information is even more critical within the highly heterogeneous Ogallala Formation, where hydraulic properties vary considerably over small lateral and vertical distances (Gutentag et al., 1984; Kreitzer, 2011). This aquifer heterogeneity would be better characterized by models that incorporate depositional mechanisms (Koltermann and Gorelick, 1996; Kreitzer, 2011), but due to incomplete knowledge of the depositional processes and timelines that governed development of the Ogallala Formation, neither depositional models nor vital hydrostratigraphic information are currently available on a broad scale (Kreitzer, 2011). Detailed stratigraphic and geochronologic information from numerous completed and planned boreholes in western Kansas is currently being applied to characterization of Ogallala Formation stratigraphy and hydraulic parameters (Zeigler et al., 
2012; Smith et al., 2014). Interpretations based on high-precision radioisotopic dates for the Ogallala Formation presented here will thus eventually help to guide groundwater management initiatives in the High Plains.

\section{METHODS}

Zircon separation was achieved by a combination of chemical and physical disaggregation and separation techniques at the University of Kansas Isotope Geochemistry Laboratories (IGL). Calcretes were first disaggregated into a fine sand and carbonate powder using a jaw crusher and disc mill before partial dissolution in $1.5 \mathrm{~N} \mathrm{HCl}$ to separate clasts from the carbonate matrix. Clay was then separated from heavier and larger mineral grains by turbulent flow in an ultrasonic bath using the method described by Hoke et al. (2014). Samples of vitric ash were bathed in cold $12 \mathrm{~N} \mathrm{HF}$ in order to dissolve the matrix of fine-grained volcanic glass. A Frantz ${ }^{\mathrm{TM}}$ isodynamic magnetic separator and methylene iodide were then used to separate the heavy, non-magnetic mineral fraction. Dissolution of barite from a paleosol heavy mineral separate (HP14-06) was carried out following a method modified from Breit et al. (1985). Zircons were then hand-picked under a binocular microscope and mounted on doublesided tape, capturing a range of morphologies while selectively picking euhedral grains that are less likely to have undergone significant fluvial transport.

Zircon separates were analyzed by LA-ICP-MS at the University of Kansas using a Photon Machines Analyte.G2 $193 \mathrm{~nm}$ ArF excimer laser ablation system feeding a Thermo Scientific Element2 ICP-MS (Appendix B). Circular $20 \mu \mathrm{m}$ spots were ablated with the laser at $2.0 \mathrm{~J} / \mathrm{cm}^{2}$ fluency and $10 \mathrm{~Hz}$ repetition rate, and a He carrier gas carried ablated material to the ICP. Downhole elemental and isotopic fractionation and calibration drift during the analytical session were corrected by bracketing measurements of unknowns with the $600.4 \pm 0.65 \mathrm{Ma}$ GJ-1 
zircon reference material (Jackson et al., 2004). Data were reduced using the VizualAge data reduction scheme (Petrus and Kamber, 2012) for the IOLITE software package (Paton et al., $2010 ; 2011)$.

Uncertainty $( \pm 2 \sigma)$ in ${ }^{206} \mathrm{~Pb} /{ }^{238} \mathrm{U}$ dates from single GJ-1 ablations is typically $\sim 8 \mathrm{Ma}$. Secondary standards including Plešovice (Sláma et al., 2008; Horstwood et al., 2016), Peixe (G. Gehrels, unpublished data), and the Fish Canyon Tuff (Wotzlaw et al., 2013) yield dates that are in agreement with TIMS analyses (Appendix C). Concordia diagrams for all data were plotted using the ISOPLOT software (Ludwig, 2008). The results of the LA-ICP-MS U-Pb analyses of unknowns are reported in Appendix D.

Sub-Ogallala Formation bedrock elevations in Kansas (Fig. 2) were estimated from structure contours by Wilson et al. (2009), and regionally based on a map by Weeks and Gutentag (1981) converted to digital contours for use in geographic information system (GIS) software by Cederstrand and Becker (1998). Land surface elevations from sample sites were measured from field GPS measurements and cross-checked against a USGS DEM of the National Elevation Dataset.

\section{RESULTS}

Abundant zircons in calcretes, bentonites, and volcanic ashes yield the first highprecision (ca. 1-5\%) radioisotopic dates measured from the Ogallala Formation. Mid-late Miocene zircons were measured in all samples, as well as older grains that range in age from early Miocene to Mesoarchean (Fig. 3). Calcretes from west-central Ellis County contain grains as young as 8.1-8.5 Ma (Figs. 4a, b), but also numerous Paleogene, Cretaceous, Jurassic, and Proterozoic ( 1100, 1400, and $1700 \mathrm{Ma})$ grains. Northwestern Ellis County calcretes include grains as young as 9.1 Ma (Figs. 4c, d), as well as a similar suite of older grains. A Norton 
County calcrete includes grains as young as 12.2 Ma (Fig. 4h), as well as a suite of older grains comparable to the age distribution derived from Ellis County samples.

A bentonite from the Calvert volcanic ash mine is dominated by middle Miocene zircons, but also includes a spectrum of older grains similar to those found in calcretes. Replicate samples from an underlying vitric ash also contain dominantly middle Miocene zircons, but with only limited inclusion of older grains. The middle Miocene zircons from the three Calvert mine samples (Figs. 4e, f, g) yield indistinguishable mean ${ }^{206} \mathrm{~Pb} /{ }^{238} \mathrm{U}$ dates of ca. 11.7 Ma.

\section{DISCUSSION}

\section{General Comments}

The provenance of zircons is discussed, followed by the significance of zircon dates to two issues. Of the two, the depositional model and implications for High Plains stratigraphic architecture is discussed in detail. Potential applications of our data and interpretations to the development of numerical groundwater models is also presented.

It should be noted that detrital age spectra may not represent a random sample of their parent population due to the selective picking of euhedral grains that were unlikely to have undergone significant fluvial transport. Statistical likeness tests (e.g. the Kolmogorov-Smirnov test) therefore cannot be rigorously applied to these potentially biased detrital populations. However, the specifics of detrital age spectra have little bearing on the conclusions presented here, and the data are nevertheless consistent with potential source terranes.

\section{Calvert Ash}

A possible source of the vitric ash at the $11.7 \mathrm{Ma}$ Calvert volcanic ash mine is one of approximately seven eruptions of the 10.5-12.7 Ma ignimbrite phase of the Bruneau-Jarbidge 
volcanic center, collectively known as the Cougar Point Tuff or CPT (Bonnichsen et al., 2008). The Bruneau-Jarbidge volcanic center is a product of the Yellowstone-Snake River Plain (YSRP) volcanic system, which initiated ca. 16 Ma near the Oregon-Idaho-Nevada border and migrated at $\sim 4 \mathrm{~cm} / \mathrm{yr}$ to its present location in northwestern Wyoming (Rodgers et al., 1990; Pierce and Morgan, 1992; Smith and Braille, 1993; Perkins et al., 1995). From 9.5-13.9 Ma, it produced frequent ( every $200 \mathrm{kyr}$ ) large silicic eruptions (Perkins et al., 1995), some of which have been recognized in the Great Plains (Perkins and Nash, 2002). Perkins (1998) tentatively correlated several ashes in northwestern Kansas to YSRP volcanic fields including Picabo, Twin Falls, and Bruneau-Jarbidge, consistent with geochronology presented here. All cited dates are based on ${ }^{40} \mathrm{Ar} /{ }^{39} \mathrm{Ar}$ analyses of proximal to medial ashes and rhyolites unless otherwise noted.

The most probable source of the Calvert ash is the voluminous $\left(>1000 \mathrm{~km}^{3}\right) 11.81 \pm 0.03$ Ma CPT VII (Nash and Perkins, 2012), which is correlative with the $11.93 \pm 0.03$ Ma Ibex Hollow ash of Perkins et al. (1998). This eruption has been identified in Smith County, KS by chemical fingerprinting (Ludvigson et al., 2009), and is interpreted as the source of the Ashfall Fossil Beds in Nebraska and the Mission Pit locality of South Dakota (Famoso and Pagnac, 2011). Other potential sources include the 11.22 \pm 0.07 Ma CPT XI (Bonnichsen et al., 2008), which has also been recognized in the Great Plains (Perkins and Nash, 2002), and the smaller 11.56 \pm 0.07 Ma Cougar Point Tuff IX (Bonnichsen et al., 2008), which probably also reached the Great Plains (Perkins and Nash, 2002).

Volcanic ash can travel great distances from eruptive centers, likely due to the irregular surface geometry of glass shards (Rose et al., 2003), or by the dispersive expansion of umbrella clouds that can drive ash thousands of kilometers against prevailing winds (Mastin et al., 2014). Miocene and later ashes preserved in the Great Plains are commonly >1000 km from their source 
(Rose et al., 2003), and the Calvert volcanic ash mine in particular is $\sim 1350 \mathrm{~km}$ downwind from its presumptive source at the Bruneau-Jarbidge volcanic center. While heavy minerals like zircon have not previously been recognized in distal ashes of terrestrial sequences, given the remarkable potential for ash to travel great distances, it is perhaps unsurprising that dense minerals like zircon do not fully fractionate from glass particles. These previously unrecognized volcanogenic zircons provide the first reliable radioisotopic dates for the Neogene High Plains at ca. 1-5\% precision. Our results imply that pyroclastic zircon might be present or even common in continental clastic sequences of the Great Plains and other basins that are far from active magmatic arcs.

Because the zircon content of vitric ashes (Figs. 4f, g) and paleosols derived from those ashes (Fig. 4e) are dominated by a pyroclastic component and contain only limited foreign epiclastic material, we interpret dates from such units as depositional ages. Given their unimodal date distribution, many such ashes might be dated quickly and relatively inexpensively as low $n$ samples by LA-ICP-MS or as single grains via the CA-TIMS method without significant risk of omitting the youngest population.

Mean dates of $\sim 11.7 \mathrm{Ma}$ are reported without uncertainties for vitric ashes and bentonites derived from those ashes due to scatter somewhat in excess of uncertainty. Weighted mean ${ }^{206} \mathrm{~Pb} /{ }^{238} \mathrm{U}$ dates for Calvert mine samples yield unacceptably high MSWDs $($ HP14-06 = 1.7 for $n$ $=172 ; \mathrm{HP} 14-07=1.5$ for $n=107)$ that might reflect a small underestimation of single-grain age uncertainties or inclusion in weighted mean calculations of zircons from geologically distinct populations. A replicate sample of the Calvert ash (HP14-05b) includes a small but consistent common $\mathrm{Pb}$ contamination that rendered $\sim 1 / 2$ of all grains discordant, potentially biasing any weighted mean age. We note that despite the potential for systematic error in weighted mean 
${ }^{206} \mathrm{~Pb}^{/ 238} \mathrm{U}$ dates calculated for HP14-05b, the data for single grains are indistinguishable from HP14-07 within uncertainty. Despite these complications, measured dates are internally consistent and likely accurate.

\section{Norton County Calcrete}

Pedogenic calcrete samples (HP14-02, -03, -08, -09b, -10b) contain rounded quartz and lithic fragments, as well as primarily detrital zircon grains with crystallization dates spanning from Archean to late Miocene time (Fig. 3). These units are interpreted as pedogenically altered fluvial deposits, and the youngest age populations are therefore interpreted as maximum depositional ages. In contrast to ash beds, whose zircon crystallization age was closely followed by deposition, the accuracy of maximum depositional ages is contingent on contribution of contemporaneous zircon from large eruptions.

The 12.2 Ma maximum depositional age of a calcrete from Almena, Norton County (Fig. 4h) makes it possibly contemporaneous with the 12.7-15.2 Ma Owyhee-Humboldt volcanic field (Perkins and Nash, 2002), but more likely contemporaneous with the 10.5-12.7 Ma ignimbrite phase of the Bruneau-Jarbidge volcanic field (Bonnichsen et al., 2008). The most probable source of young zircons may be the $12.66 \pm 0.02$ Ma CPT III (Bonnichsen et al., 2008), which has previously been recognized in the Great Plains (Perkins and Nash, 2002).

\section{Ellis County Calcretes}

In contrast to the middle Miocene dates of Norton County, zircons from calcretes in Ellis County are late Miocene in age and yield 8.1-9.1 Ma maximum depositional ages (Fig. 4a, b, c, d) contemporaneous with the 8.5-10.5 Ma Twin Falls volcanic field (Perkins and Nash, 2002) and the 6.7-10.4 Ma Picabo volcanic field (Anders et al., 2014). Eruptions contributing 
young zircon probably include the voluminous and widespread 10.79 \pm 0.04 Ma CPT XIII (Bonnichsen et al., 2008) from the Bruneau-Jarbidge volcanic field and the widespread $10.13 \pm 0.03$ Ma Tuff of Wooden Shoe Butte from the Twin Falls volcanic field (Perkins and Nash, 2002). These eruptions are too old to account for the youngest detrital grains measured, but those grains are generally contemporaneous with dated ashfalls previously recognized in the Great Plains (Perkins and Nash, 2002), including the 8.94 \pm 0.07 Ma Tuff of McMullen Creek (Nash et al., 2006), the 8.6 \pm 0.1 Ma Inkom ash (Nash et al., 2006), and the $8.4 \pm 0.2 \mathrm{Ma}$ Rush Valley ash (Nash et al., 2006). Young zircons might also owe their provenance to the $9.8 \pm 0.2$ Ma Hazen ash, which was dated by interpolation of measured sections (Perkins et al., 1998) or the $9.4 \pm 0.5$ Ma Mink Creek ash (Nash et al., 2006). Neither of these ashes have been previously recognized in the Great Plains.

Ellis County zircon ages are consistent with the findings of Tallan (1978) and Zakrzewski (1990) who recognized early Hemphillian (4.9-10.3 Ma) land mammals and salamanders from an exposure coined the Bemis Local Fauna locality, located $\sim 600 \mathrm{~m}$ to the southwest of a sampled outcrop (HP14-09b) at similar stratigraphic levels. These ages are younger than the probably inaccurate $18 \pm 3.6$ Ma volcanic glass K-Ar date reported from Ellis County, $700 \mathrm{~m}$ southwest of HP14-09b (Thomasson, 1979).

\section{Complications in Determining Provenance}

Correlation of specific eruptive events, often dated using sanidine by the Ar-Ar system, to ashes recognized in the Great Plains, here dated using zircon and the U-Pb system, is made more difficult by a poorly quantified systematic bias between dates from the U-Pb and $\mathrm{Ar}-\mathrm{Ar}$ isotopic systems. Potential uncertainties on the order of $1 \%$ for weighted mean ${ }^{206} \mathrm{~Pb} /{ }^{238} \mathrm{U}$ zircon ages would likely allow unambiguous correlation between Ogallala Formation ashes and 
proximal YSRP tuffs and rhyolites if not for an imprecise and potentially inaccurate intercalibration of up to $2 \%$ between dates from the U-Pb and ${ }^{40} \mathrm{Ar}^{-39} \mathrm{Ar}$ chronometers (Renne et al., 2010). Low $n$ populations and uncertainty on the order of $5 \%$ for single-grain LA-ICP-MS dates precludes the correlation of individual zircons from detrital units to specific eruptions. However, temporal assignments of provenance in vitric ashes can be corroborated by petrographic arguments including shard morphology and index of refraction (e.g. Potter, 1991), or by trace element and isotopic fingerprinting of volcanic glass (e.g. Perkins, 1998; David, 2006). Further trace element characterizations of Miocene ashes in the High Plains would facilitate more precise correlations. Despite the uncertainties involved, new U-Pb dates and existing geologic information permit the robust correlation of volcanic ashes to specific volcanic fields and the tentative correlation of High Plains ashes to specific eruptive events.

\section{Ash Depositional Environment}

Most volcanic ashes in Kansas were originally interpreted as aeolian deposits that accumulated in hollows and on the leeward side of hills (Landes, 1928). More recent study has demonstrated that ashes in Kansas typically lack aeolian cross-bedding, and are often underlain by clay with interbedded gastropod and ostracod shells, indicating deposition in shallow ponded water (Carey et al., 1952; Swineford, 1963; Diffendal, 1982). Norton County ashes in particular are consistent with subaqueous deposition due to their dense packing and horizontal laminations (Landes, 1928). Standing water in the High Plains is currently restricted to small sandhills lakes

(Gutentag et al., 1984), as well as 22,000 extant playas in Kansas alone (Bowen et al., 2010). These playas are typically small, closed depressions that develop as aeolian scours and often persist in a given location as sediments aggrade around them (Holliday et al., 1996). They likely record sediment influx events in a reliable stratigraphic order as they concentrate local runoff and 
entrap sediments (Bowen et al., 2010) including volcanic ash (Cornwell, 1984). Playas are common both on the present surface of the High Plains, and within the Miocene Ogallala Formation (Holliday et al., 1996), and are thus the favored depositional environment for the Calvert ash. Remobilization of topography-mantling ashes and redeposition in playas accounts for the lenticular nature of ash deposits in Kansas (Carey et al., 1952), but makes them difficult to correlate over significant distances (Cornwell, 1984). Most of the recharge that enters the Ogallala-High Plains aquifer probably occurs as seepage from playas (Stone, 1990; Holliday et al., 1996), so understanding these features and their temporal evolution is critical to characterization of the High Plains water budget.

\section{Depositional Model}

Early workers assumed that the Ogallala Formation was deposited in an alluvial plain environment as a series of coalesced fans running the length of the Rocky Mountain front (Johnson, 1901; Smith, 1940; Frye and Leonard, 1964). The assumption that trunk streams sourced from ranges separated by hundreds of kilometers were synchronous may not be valid due to the potential for distinct uplift histories, asynchronous spillover from closed basins, and local differences in erosion (Ludvigson et al., 2009). More recent study of fluvial facies and lithological differences indicates that the Ogallala Formation may have been deposited as a series of temporally distinct, laterally discontinuous DFS lobes (Skinner and Johnson, 1984; Chapin, 2008; Galloway et al., 2011; Harlow, 2013). This model, proposed by Seni (1980) based on work in the Texas panhandle, and adopted by Skinner and Johnson (1984) for Nebraska and South Dakota involves the filling and overtopping of paleovalleys, followed by avulsion to lower topography. The dominantly aeolian facies recognized more recently in the southern High Plains (Gustavson and Winkler, 1988) undercuts the conclusions of Seni (1980) in that area, but the 
fluvial deposits that dominate north of the Canadian River (Holliday, 1991) remain consistent with diachronous aggradation of fluvial lobes. In particular, the recognition of diachronous paleodrainage systems in Nebraska and South Dakota by Skinner and Johnson (1984) remains a viable depositional model.

These competing hypotheses predict different spatial and temporal patterns of deposition: the alluvial plain model predicts nearly contemporaneous deposition of geographically extensive sequences and their correlatives over large areas along strike and down dip. In this model, deposition should proceed synchronously across the extent of the formation, with superposition dominating an orderly age progression occasionally disrupted by second-order scours and channel fills. In contrast to the alluvial plain model, the DFS model predicts lithologically similar but laterally diachronous eastward-prograding lobes that maintain internal superposition. These predictions can be evaluated by analyzing the three-dimensional distribution of depositional ages within the context of a basal unconformity that reveals Cenozoic topography. Though conclusions drawn from interpreted bedrock elevation data are probably useful and reasonably accurate, they should not be over-interpreted given the $\sim 15 \mathrm{~m}$ uncertainty in these measurements (Wilson et al., 2009), which approaches the total land surface relief encountered in this study. Despite substantial evidence for Pliocene uplift of the High Plains, modern elevations are used as a proxy for paleoelevations due to the interpreted tilting gradient of $\sim 0.001$ (Heller et al., 2003). Tilting of this magnitude is unlikely to introduce measurable systematic error into elevation comparisons between samples in proximity to one another that sit along the strike of tilting.

Figure 5 illustrates that middle Miocene depositional ages were measured from Norton County outcrops at modern elevations ranging from 680-690 m. The sampled sequence is exposed in part by incision by the modern Prairie Dog Creek, which appears to coincide with a 
pre-Ogallala drainage incised into the Cretaceous Niobrara Chalk (Fig. 2). The maximum depositional age of a calcrete sampled near Almena (HP14-08) indicates that ca. 12.2 Ma or later, the Ogallala Formation had aggraded to $\sim 40 \mathrm{~m}$ above the bedrock valley in that vicinity. At 11.7 Ma, the Calvert ash was then deposited $\sim 10 \mathrm{~m}$ above and $6300 \mathrm{~m}$ upstream of the Almena calcrete along the paleovalley extending to the southwest, at $\sim 30 \mathrm{~m}$ above the Cretaceous surface and far above the former confines of the pre-Ogallala valley. Thus by $11.7 \mathrm{Ma}$, the Ogallala Formation had filled and overtopped its confining bedrock valley in the vicinity of Prairie Dog Creek, aggrading to its modern elevation of $\sim 690 \mathrm{~m}$ and reaching a thickness of $\sim 30-40 \mathrm{~m}$. Other mid-Miocene depositional ages have been applied to ashes from Kansas' northernmost counties: Landes (1928) correlated ashes from Rawlins County with the Calvert ash, and Ludvigson et al. (2009) correlated an ash from Smith County with the 11.93 Ma Ibex Peak Tuff.

Late Miocene maximum depositional ages were measured from Ellis County outcrops at modern elevations ranging from 670-680 m (Fig. 5). These units are partially exposed by the escarpment that separates the Ogallala-defined High Plains from the Plains Border region, placing them close to the pre-Ogallala basal unconformity. Maximum depositional ages of calcretes from northwestern Ellis County indicate that ca. 9.1 Ma or later, the Ogallala Formation had aggraded $\sim 15 \mathrm{~m}$ above bedrock to an elevation of $\sim 680 \mathrm{~m}$. A calcrete from west-central Ellis County (HP14-09b) indicates that ca. 8.5 Ma or later, the Ogallala Formation had aggraded $<5 \mathrm{~m}$ above bedrock to an elevation of $\sim 670 \mathrm{~m}$. A second calcrete from the same section (HP14-10b) indicates that ca. 8.1 Ma or later, aggradation had progressed by another $10 \mathrm{~m}$ to $\sim 680 \mathrm{~m}$. Aggradation in Ellis County therefore probably began shortly prior to $\sim 9.1 \mathrm{Ma}$, and by $\sim 8.1 \mathrm{Ma}$ had likely progressed to a modern elevation comparable to or lower than had been achieved in Norton County by $11.7 \mathrm{Ma}$. 
The proximity of Cretaceous bedrock to Ellis County calcretes implies that aggradation in this area likely began shortly prior to the measured maximum depositional ages. Deposition of the Ogallala Formation was thought to have initiated ca. $17 \mathrm{Ma}$ in the northern High Plains and ca. $12 \mathrm{Ma}$ in the southern High Plains (Roy et al., 2004). The inferred 9-10 Ma deposition of basal Ogallala Formation in Ellis County might therefore indicate a younger and more diachronous depositional history than was previously suspected for parts of the formation.

The low relief surface of the modern High Plains means that surface outcrops in Norton and Ellis counties sit at nearly the same elevation, yet these beds differ in age by $~ 3$ Myr over an along-strike distance of $\sim 100 \mathrm{~km}$. The inferred $\sim 30-35 \mathrm{~m}$ depth to pre-Cenozoic bedrock beneath the Calvert ash indicates that aggradation in Norton County had reached an advanced stage by 11.7 Ma, in contrast to the basal units of Ellis County, which were likely not deposited until ca. 9-10 Ma. Ogallala deposits in Norton County must have therefore formed a topographic high relative to Ellis County before deposition in that area. These observations are inconsistent with predictions made by the alluvial plain model, which predicts that Norton and Ellis Counties would become alluviated at around the same time, given that they fall approximately along the strike of the Cretaceous bedrock surface and parallel to the Front Range.

The DFS lobe model provides a more satisfactory explanation. We propose that deposition of the Ogallala Formation in northern and central Kansas progressed as a series of at least two asynchronous DFS lobes, illustrated in Figure 6. The Norton lobe likely spread to the north of a central Kansas bedrock high ca. 12-13 Ma and aggraded in the vicinity of the KansasNebraska border until sedimentation to levels above the former topographic barrier ca. 11.7 Ma caused avulsion into central Kansas ca. 9-10 Ma, forming the Ellis lobe. Further dating efforts concentrated in southwestern Kansas might help to better define an inferred Haskell lobe that 
potentially spans between the Ellis lobe and the aeolian sequence recognized in the southern High Plains.

This conjectured Haskell lobe may have already been identified: recent and in-progress $\mathrm{U}-\mathrm{Pb}$ zircon geochronology and petrography from the HP1A core (Fig. 2) indicates that southwestern Kansas might host a White River Group equivalent that was previously unrecognized in Kansas (Smith et al., 2014; Turner et al., 2015; Smith et al., 2016). The 29-37 Ma White River Group is a relatively homogenous, fine-grained, aeolian and volcaniclastic sequence that underlies the Arikaree Group in Nebraska (Swinehart et al., 1985). These EoceneOligocene deposits potentially constitute the southwestern Kansas Haskell lobe (Fig. 6) inferred between the Ellis lobe and the aeolian facies recognized in the southern High Plains. Age discrepancies larger than that inferred between the Norton and Ellis lobes might therefore exist within the Cenozoic terrestrial sequence of Kansas. Recognition of such lithologically disparate strata may inform the development of numerical groundwater models, which rely on sedimentological characteristics including grain size, porosity, and sorting for the selection of hydraulic parameters.

\section{Significance of Results to the Ogallala-High Plains Aquifer}

Fine-grained units typically have limited porosity and hydraulic conductivity, limiting their capacity to store and transmit water (Anderson and Woessner, 1992). The recent discovery based on age and sedimentological characteristics of a relatively fine-grained White River Group equivalent in southwestern Kansas in the vicinity of the HP1A core (Smith et al., 2014; Smith et al., 2016) occurs in a zone of relatively low hydraulic conductivity (Liu et al., 2010; Butler et al., 2016) that hosts the most severe aquifer drawdowns in Kansas (McGuire, 2009; Butler et al., 
2016). Further delineation of this potential "Haskell lobe" and other low-hydraulic conductivity units will be critical to the understanding of spatial variations in groundwater resources.

Investigations into aquifer dynamics and development of numerical groundwater models might be best guided by the hypothesis that the aquifer is subdivided into eastward prograding DFS lobes. Such lobes may include zones of stacked, high-hydraulic conductivity channel deposits separated by interlobe zones of relatively low hydraulic conductivity (van Dijk et al., 2016). The aquifer therefore likely exhibits considerable anisotropy, with coarse-grained DFS channels forming east-trending high hydraulic conductivity pathways separated by low hydraulic conductivity interlobe zones. Hydraulic properties change significantly over small lateral distances, but such discontinuities can be better understood and predicted by a thorough understanding of age relationships. Knowledge of these differences will be critical to the future development of aquifer management strategies.

\section{CONCLUSIONS}

Miocene volcanic eruptions from the Yellowstone hotspot track in southern Idaho carried ash and volcanogenic zircon to the High Plains of western Kansas. The ash falls mantled topography before being remobilized and concentrated into playas eroded into the surface of the contemporaneous Ogallala Formation. These lenticular and small but numerous playa deposits contain dateable material that provides high precision (ca. 1-5\% uncertainty) chronostratigraphic information for the Ogallala Formation. Refinement of LA-ICP-MS dates for previously dated young grains via the CA-TIMS method may be a fruitful avenue for further study, offering the potential to refine uncertainties to $<1 \%$. Depositional ages from ash beds are consistent with maximum depositional ages from fluvial sands and pedogenic calcretes, indicating that these units can be dated with some reliability due to the frequent contribution of pyroclastic zircons 
from magmatic centers in the western United States. The ash-bearing potential of volcanic arcs is widely appreciated, but perhaps underappreciated is the potential for large-volume eruptions to blanket large areas far from eruptive centers. These "supereruptions" might commonly enable high-precision $\mathrm{U}-\mathrm{Pb}$ zircon dating of distal clastic basins worldwide.

Mid-late Miocene depositional timing of the Ogallala Formation in Kansas is consistent with previous studies, but high-precision geochronology reveals previously obscured spatial patterns that indicate a more diachronous depositional history than was formerly suspected. Middle Miocene deposition of a northern Kansas Norton lobe ca. 11-13 Ma preceded deposition of the late Miocene Ellis lobe over an area of Miocene high topography in central Kansas ca. 810 Ma. An inferred Haskell lobe and White River Group equivalent likely aggraded in late Eocene or early Oligocene time in southern Kansas (Smith et al., 2014; Turner et al., 2015; Smith et al., 2016). These DFS lobes potentially form the "missing link" between the paleodrainages recognized by Skinner and Johnson (1984) in Nebraska and the aeolian facies recognized in the southern High Plains by Gustavson and Winkler (1988).

Further dating of ashes and clastic units will help to refine understanding of the spatial relationships and stratigraphic architecture of the High Plains, and can inform other longstanding regional geologic problems. For instance, the interplays between Neogene climate change and Rocky Mountain uplift and tectonics are an area of active research. The data presented here do not unambiguously implicate either mechanism as the cause of Ogallala aggradation, but further dating efforts should help to pinpoint the onset of Ogallala deposition and any contemporaneous climatic or tectonic forcing mechanisms. Additionally, zircon dates derived from the Ogallala Formation in Kansas are broadly consistent with previously published biostratigraphic correlations. Absolute radioisotopic ages should help to date with previously unattainable 
precision Miocene floral zones and faunal assemblages from the Clarendonian and Hemphillian land mammal ages. 


\section{REFERENCES}

Anders, M.H., Rodgers, D.W., Hemming, S.R., Saltzman, J., DiVenere, V.J., Hagstrum, J.T., Embree, G.F., and Walter, R.C., 2014, A fixed sublithospheric source for the late Neogene track of the Yellowstone hotspot: Implications of the Heise and Picabo volcanic fields: Journal of Geophysical Research: Solid Earth, v. 119, p. 2871-2906.

Anderson, M.P. and Woessner, W.W., 1992, Applied Groundwater Modeling: Simulation of Flow and Advective Transport: San Diego, California, Academic Press, 381 p.

Bartley, K.J., 2005, A taphonomic study of Clarendonian (Miocene) Teleoceras (Perissodactyla, Rhinocerotoidea) from the Ogallala Formation, northwestern Kansas [M.S. thesis]: Buffalo, NY, State University of New York at Buffalo, $122 \mathrm{p}$.

Bennett, D.K., 1983, Cenozoic rocks and faunas of north-central Kansas [Ph.D. dissertation]: Lawrence, KS, University of Kansas, $221 \mathrm{p}$.

Birkeland, P.W., 1999, Soils and Geomorphology: New York, New York, Oxford University Press, $430 \mathrm{p}$.

Boellstorff, J., 1976, The succession of late Cenozoic volcanic ashes of the Great Plains: a progress report, in Bayne, C.K., ed., Guidebook: 24th Annual Meeting, Midwestern Friends of the Pleistocene: Kansas Geological Survey Guidebook Series 1, p. 37-71.

Bonnichsen, B., Leeman, W.P., Honjo, N., McIntosh, W.C., and Godchaux, M.M., 2008, Miocene silicic volcanism in southwestern Idaho: geochronology, geochemistry, and evolution of the central Snake River Plain: Bulletin of Volcanology, v. 70, p. 315-342.

Bowen, M.W., Johnson, W.C., Egbert, S.L., and Klopfenstein, S.T., 2010, A GIS-based approach to identify and map playa wetlands on the High Plains, Kansas, USA: Wetlands, v. 30, p. 675-684.

Bowring, S.A. and Schmitz, M.D., 2003, High-precision U-Pb zircon geochronology and the stratigraphic record: Reviews in Mineralogy and Geochemistry, v. 53, p. 305-326.

Breit, G.N., Simmons, E.C., and Goldhaber, M.B., 1985, Dissolution of barite for the analysis of strontium isotopes and other chemical and isotopic variations using aqueous sodium carbonate: Chemical Geology: Isotope Geoscience section, v. 52, p. 333-336.

Burgess, S.D., Bowring, S., and Shen, S.Z., 2014, High-precision timeline for Earth's most severe extinction: Proceedings of the National Academy of Sciences, v. 111, p. 3316-3321.

Butler, J.J., Jr., Whittemore, D.O., Reboulet, E., Knobbe, S., Wilson, B.B., Stotler, R.L., and Bohling, G.C., 2016, High Plains aquifer index well program: 2015 annual report: Kansas Geological Survey, Open-File Report 2016-4, 179 p.

Carey, J.S., Frye, J.C., Plummer, N., and Swineford, A., 1952, Kansas volcanic ash resources: Kansas Geological Survey, Bulletin 96, pt. 1, p. 1-68.

Cederstrand, J.R. and Becker, M.F., 1998, Digital map of base of aquifer for High Plains Aquifer in parts of Colorado, Kansas, Nebraska, New Mexico, Oklahoma, South Dakota, Texas, and Wyoming: U.S. Geological Survey Open-File Report 98-393.

Cepeda, J.C. and Perkins, M.E., 2006, A 10 million year old ash deposit in the Ogallala Formation of the Texas Panhandle: Texas Journal of Science, v. 58, p. 3-12.

Chapin, C.E., 2008, Interplay of oceanographic and paleoclimate events with tectonism during middle to late Miocene sedimentation across the southwestern USA: Geosphere, v. 4, p. 976-991.

Cornwell, K.J., 1984, Evaluation of volcanic ash as a stratigraphic marker in playa basins, western Texas [M.S. thesis]: Lubbock, TX, Texas Tech University, 47 p. 
Darton, N.H., 1903, Preliminary report on the geology and water resources of Nebraska west of the one hundred and third meridian: U.S. Geological Survey Professional Paper 17, 69 p.

David, B.T., 2006, "Chemical fingerprinting" of volcanic tephra found in Kansas using trace elements [M.S. thesis]: Manhattan, KS, Kansas State University, 115 p.

Dennehy, K.F., Litke, D.W., and McMahon, P.B., 2002, The High Plains aquifer, USA: groundwater development and sustainability, in Hiscock, K.M., Rivett, M.O., and Davidson, R.M., eds., Sustainable Groundwater Development: Geological Society of London Special Publication 193, p. 99-119.

Diffendal, R.F., 1982, Regional implications of the geology of the Ogallala Group (upper Tertiary) of southwestern Morrill County, Nebraska, and adjacent areas: Geological Society of America Bulletin, v. 93, p. 964-976.

Duller, R.A., Whittaker, A.C., Swinehart, J.B., Armitage, J.J., Sinclair, H.D., Bair, A., and Allen, P.A., 2012, Abrupt landscape change post-6 Ma on the central Great Plains, USA: Geology, v. 40, p. 871-874.

Dunne, G., 2013, A geological and sedimentological approach to infer paleoclimate from buried soils profiles within playa fills, southern High Plains, Texas [M.S. thesis]: Lubbock, TX, Texas Tech University, $185 \mathrm{p}$.

Eaton, G.P., 1987, Topography and origin of the southern Rocky Mountains and Alvarado Ridge, in Coward, M.P., Dewey, J.F., and Hancock, P.L., eds., Continental Extensional Tectonics: Geological Society of London Special Publication 28, p. 355-369.

Famoso, N.A. and Pagnac, D., 2011, A comparison of the Clarendonian equid assemblages from the Mission Pit, South Dakota and Ashfall Fossil Beds, Nebraska: Transactions of the Nebraska Academy of Sciences, v. 32, p. 98-107.

Fenneman, N.M., 1917, Physiographic Subdivision of the United States: Proceedings of the National Academy of Sciences, v. 3, p. 17-22.

Field, H.L., Ludvigson, G.A., Möller, A., Joeckel, R.M., and Stotler, R.L., 2015, Chronostratigraphic interpretations of Cenozoic paleosols in Nebraska using integrated U$\mathrm{Pb}$ dating and carbon isotope chemostratigraphy: Geological Society of America Abstracts with Programs, v. 47, p. 595.

Fielding, C.R., LaGarry, H.E., LaGarry, L.A., Bailey, B.E., and Swinehart, J.B., 2007, Sedimentology of the Whiteclay Gravel Beds (Ogallala Group) in northwestern Nebraska, USA: Structurally controlled drainage promoted by Early Miocene uplift of the Black Hills Dome: Sedimentary Geology, v. 202, p. 58-71.

Fogg, G.E., Noyes, C.D., and Carle, S.F., 1998, Geologically based model of heterogeneous hydraulic conductivity in an alluvial setting: Hydrogeology Journal, v. 6, p.131-143.

Frye, J.C. and Leonard, A.B., 1949, Geology and ground-water resources of Norton County and northwestern Phillips County, Kansas: Kansas Geological Survey, Bulletin 81, 144 p.

Frye, J.C. and Leonard, A.B., 1964, Relation of Ogallala Formation to the southern High Plains in Texas: Texas Bureau of Economic Geology Report of Investigations 51, 25 p.

Frye, J.C., Leonard, A.B., and Swineford, A., 1956, Stratigraphy of the Ogallala Formation (Neogene) of northern Kansas: Kansas Geological Survey, Bulletin 118, 92 p.

Furin, S., Preto, N., Rigo, M., Roghi, G., Gianolla, P., Crowley, J.L., and Bowring, S.A., 2006, High-precision U-Pb zircon age from the Triassic of Italy: Implications for the Triassic time scale and the Carnian origin of calcareous nannoplankton and dinosaurs: Geology, v. 34, p. 1009-1012. 
Galloway, W.E., Whiteaker, T.L., and Ganey-Curry, P., 2011, History of Cenozoic North American drainage basin evolution, sediment yield, and accumulation in the Gulf of Mexico basin: Geosphere, v. 7, p. 938-973.

Global Volcanism Program, 2013, Volcanoes of the World, v. 4.4.3, Venzke, E., ed., Smithsonian Institution: accessed 18 May 2016 <http://dx.doi.org/10.5479/si.GVP.VOTW4-2013>.

Goodwin, R.G. and Diffendal, R.F., Jr., 1987, Paleohydrology of some Ogallala (Neogene) streams in the southern panhandle of Nebraska, in Ethridge, F.G., Flores, R.M., and Harvey, M.D., eds., Recent Developments in Fluvial Sedimentology: SEPM Special Publication 39, p. 149-158.

Gustavson, T.C., and Winkler, D.A., 1988, Depositional facies of the Miocene-Pliocene Ogallala Formation, northwestern Texas and eastern New Mexico: Geology, v. 16, p. 203-206.

Gutentag, E.D., Heimes, F.J., Krothe, N.C., Luckey, R.R., and Weeks, J.B., 1984, Geohydrology of the High Plains aquifer in parts of Colorado, Kansas, Nebraska, New Mexico, Oklahoma, South Dakota, Texas, and Wyoming: U.S. Geological Survey Professional Paper 1400-B, 63 p.

Harlow, R.H., 2013, Depositional and paleoclimatic evolution of the Cenozoic High Plains Succession from core: Haskell Co., Kansas [M.S. thesis]: Lawrence, KS, University of Kansas, 124 p.

Hawley, J.W, Bachman, G.O., and Manley, K., 1976, Quaternary stratigraphy in the Basin and Range and Great Basin provinces, New Mexico and western Texas, in Mahaney, W.C., ed., Quaternary Stratigraphy of North America: Stroudsburg, PA, Dowden, Hutchinson, \& Ross, p. 235-274.

Heller, P.L., Angevine, C.L., Winslow, N.S., and Paola, C., 1988, Two-phase stratigraphic model of foreland-basin sequences: Geology, v. 16, p. 501-504.

Heller, P.L., Dueker, K., and McMillan, M.E., 2003, Post-Paleozoic alluvial gravel transport as evidence of continental tilting in the US Cordillera: Geological Society of America Bulletin, v. 115, p.1122-1132.

Hoke, G.D., Schmitz, M.D., and Bowring, S.A., 2014, An ultrasonic method for isolating non-clay components from clay-rich material: Geochemistry, Geophysics, Geosystems, v. 15, p. 492-498.

Holliday, V.T., 1991, The geologic record of wind erosion, eolian deposition, and aridity on the Southern High Plains: Great Plains Research, v. 1, p. 6-25.

Holliday, V.T., Hovorka, S.D., and Gustavson, T.C., 1996, Lithostratigraphy and geochronology of fills in small playa basins on the Southern High Plains, United States: Geological Society of America Bulletin, v. 108, p. 953-965.

Horstwood, M.S.A., Košler, J., Gehrels, G., Jackson, S.E., McLean, N.M., Paton, C., Pearson, N.J., Sircombe, K., Sylvester, P., Vermeesch, P., Bowring, J.F., Condon, D.J., and Schoene, B., 2016, Community-derived standards for LA-ICP-MS U-(Th-)Pb geochronology - uncertainty propagation, age interpretation and data reporting: Geostandards and Geoanalytical Research, doi:10.1111/j.1751-908X.2016.00379.x, 22 p.

Izett, G.A. and Wilcox, R.E., 1982, Map showing localities and inferred distributions of the Huckleberry Ridge, Mesa Falls, and Lava Creek ash beds (Pearlette family ash beds) of Pliocene and Pleistocene age in the western United States and southern Canada: U.S. Geological Survey Miscellaneous Investigations Map I-1325, scale 1:400,000. 
Jackson, S.E., Pearson, N.J., Griffin, W.L., and Belousova, E.A., 2004, The application of laser ablation-inductively coupled plasma-mass spectrometry to in situ U-Pb zircon geochronology: Chemical Geology, v. 211, p. 47-69.

Jochum, K.P., Weis, U., Stoll, B., Kuzmin, D., Yang, Q., Raczek, I., Jacob, D.E., Stracke, A., Birbaum, K., Frick, D.A., Günther, D., and Enzweiler, J., 2011, Determination of reference values for NIST SRM 610-617 glasses following ISO guidelines: Geostandards and Geoanalytical Research, v. 35, p. 397-429.

Johnson, W.D., 1901, The High Plains and their utilization: Report of the U.S. Geological Survey, v. 21 , p. 609-741 and v. 22 , p. $640-669$.

Kansas Geological Survey, 2008, Surficial geology of Kansas: Kansas Geological Survey, Map M-118, scale 1:500,000.

Koltermann, C.E. and Gorelick, S.M., 1996, Heterogeneity in sedimentary deposits: A review of structure-imitating, process imitating, and descriptive approaches: Water Resources Research, v. 32, p. 2617-2658.

Kraus, M.J., 1999, Paleosols in clastic sedimentary rocks: their geologic applications: EarthScience Reviews, v. 47, p. 41-70.

Kreitzer, S.R., 2011, An evaluation of hydrostratigraphic characterization methods based on well logs for groundwater modeling of the High Plains aquifer in southwest Kansas [M.S. thesis]: Lawrence, KS, University of Kansas, $100 \mathrm{p}$.

Kustu, M.D., Fan, Y., and Robock, A., 2010, Large-scale water cycle perturbation due to irrigation pumping in the US High Plains: A synthesis of observed streamflow changes: Journal of Hydrology, v. 390, p. 222-244.

Landes, K.K., 1928, Volcanic ash resources of Kansas: Kansas Geological Survey, Bulletin 14, 58 p.

Leonard, E.M., 2002, Geomorphic and tectonic forcing of late Cenozoic warping of the Colorado piedmont: Geology, v. 30, p. 595-598.

Liu, G., Wilson, B., Whittemore, D., Jin, W., and Butler, J., Jr., 2010, Ground-water model for Southwest Kansas Groundwater Management District No. 3: Kansas Geological Survey, Open-File Report 2010-18, 109 p.

Ludvigson, G.A., Sawin, R.S., Franseen, E.K., Watney, W.L., West, R.R., and Smith, J.J., 2009, A review of the stratigraphy of the Ogallala Formation and revision of Neogene ("Tertiary") nomenclature in Kansas: Kansas Geological Survey, Bulletin 256, pt. 2, 9 p.

Ludwig, K.R., 2008, User's Manual for Isoplot 3.70: a geochronological toolkit for Microsoft Excel: Berkeley Geochronology Center Special Publication 4, 76 p.

Macfarlane, P.A., 2009, New insights into the hydrostratigraphy of the High Plains aquifer from three-dimensional visualizations based on well records: Geosphere, v. 5, p. 51-58.

Mastin, L.G., Guffanti, M., Servranckx, R., Webley, P., Barsotti, S., Dean, K., Durant, A., Ewert, J.W., Neri, A., Rose, W.I., Schneider, D., Siebert, L., Stunder, B., Swanson, G., Tupper, A., Volentik, A., and Waythomas, C.F., 2009a, A multidisciplinary effort to assign realistic source parameters to models of volcanic ash-cloud transport and dispersion during eruptions: Journal of Volcanology and Geothermal Research, v. 186, p. 10-21.

Mastin, L.G., Guffanti, M., Ewert, J.E., and Spiegel, J., 2009b, Preliminary spreadsheet of eruption source parameters for volcanoes of the world: U.S. Geological Survey Open-File Report 09-1133, v. 1.2, 25 p.

Mastin, L.G., Van Eaton, A.R., and Lowenstern, J.B., 2014, Modeling ash fall distribution from a Yellowstone supereruption: Geochemistry, Geophysics, Geosystems, v. 15, p. 3459-3475. 
McGuire, V.L., 2009, Water-level changes in the High Plains aquifer, predevelopment to 2007, 2005-06, and 2006-07: U.S. Geological Survey Scientific Investigations Report 20095019,9 p.

McMillan, M.E., Angevine, C.L., and Heller, P.L., 2002, Postdepositional tilt of the MiocenePliocene Ogallala Group on the western Great Plains: Evidence of late Cenozoic uplift of the Rocky Mountains: Geology, v. 30, p. 63-66.

McMillan, M.E., Heller, P.L., and Wing, S.L., 2006, History and causes of post-Laramide relief in the Rocky Mountain orogenic plateau: Geological Society of America Bulletin, v. 118, p. 393-405.

Molnar, P., 2004, Late Cenozoic increase in accumulation rates of terrestrial sediment: how might climate change have affected erosion rates? Annual Review of Earth and Planetary Sciences, v. 32, p. 67-89.

Molnar, P. and England, P., 1990, Late Cenozoic uplift of mountain ranges and global climate change: chicken or egg? Nature, v. 346, p. 29-34.

Moore, R.C., Frye, J.C., Jewett, J.M., Lee, W., and O'Connor, H.G., 1951, The Kansas Rock Column: Kansas Geological Survey, Bulletin 89, 132 p.

Mundil, R., Ludwig, K.R., Metcalfe, I., and Renne, P.R., 2004, Age and timing of the Permian mass extinctions: $\mathrm{U} / \mathrm{Pb}$ dating of closed-system zircons: Science, v. 305, p. 1760-1763.

Naeser, C.W., Izett, G.A., and Obradovich, J.D., 1980, Fission-track and K-Ar ages of natural glasses: U.S. Geological Survey Bulletin 1489, 31 p.

Nash, B.P. and Perkins, M.E., 2012, Neogene fallout tuffs from the Yellowstone hotspot in the Columbia plateau region, Oregon, Washington and Idaho, USA: PLoS One, v. 7, 13 p.

Nash, B.P., Perkins, M.E., Christensen, J.N., Lee, D.C., and Halliday, A.N., 2006, The Yellowstone hotspot in space and time: $\mathrm{Nd}$ and Hf isotopes in silicic magmas: Earth and Planetary Science Letters, v. 247, p. 143-156.

Neuhauser, K.R. and Pool, J.C., 1988, Geologic map, Ellis County, Kansas: Kansas Geological Survey, Map M-19, scale 1:53,870, 48 x 39 inches.

Newell, A.J., 2001, Bounding surfaces in a mixed aeolian-fluvial system (Rotliegend, Wessex Basin, SW UK): Marine and Petroleum Geology, v. 18, p. 339-347.

North, C.P. and Prosser, D.J., 1993, Characterization of fluvial and aeolian reservoirs: problems and approaches, in North, C.P. and Prosser, D.J., eds., Characterization of Fluvial and Aeolian Reservoirs: Geological Society of London Special Publication 73, p. 1-6.

Oskin, M. and Stock, J., 2003, Marine incursion synchronous with plate-boundary localization in the Gulf of California: Geology, v. 31, p. 23-26.

Paton, C., Hellstrom, J., Paul, B., Woodhead, J., and Hergt, J., 2011, Iolite: Freeware for the visualisation and processing of mass spectrometric data: Journal of Analytical Atomic Spectrometry, v. 26, p. 2508-2518.

Paton, C., Woodhead, J.D., Hellstrom, J.C., Hergt, J.M., Greig, A., and Maas, R., 2010, Improved laser ablation $\mathrm{U}-\mathrm{Pb}$ zircon geochronology through robust downhole fractionation correction: Geochemistry, Geophysics, Geosystems, v. 11, 36 p.

Perkins, M.E., 1998, Tephrochronologic and volcanologic studies of silicic fallout tuffs in Miocene basins of the northern Basin and Range Province, U.S.A. [Ph.D. dissertation]: Salt Lake City, UT, University of Utah, $206 \mathrm{p}$.

Perkins, M.E., Brown, F.H., Nash, W.P., McIntosh, W., and Williams, S.K., 1998, Sequence, age, and source of silicic fallout tuffs in middle to late Miocene basins of the northern Basin and Range province: Geological Society of America Bulletin, v. 110, p. 344-360. 
Perkins, M. and Nash, B., 2002, Explosive silicic volcanism of the Yellowstone hotspot: the ash fall tuff record: Geological Society of America Bulletin, v. 114, p. 367-381.

Perkins, M.E., Nash, W.P., Brown, F.H., and Fleck, R.J., 1995, Fallout tuffs of Trapper Creek, Idaho-a record of Miocene explosive volcanism in the Snake River Plain volcanic province: Geological Society of America Bulletin, v. 107, p. 1484-1506.

Petrus, J.A. and Kamber, B.S., 2012, VizualAge: A novel approach to laser ablation ICP-MS U$\mathrm{Pb}$ geochronology data reduction: Geostandards and Geoanalytical Research, v. 36, p. 247270.

Pierce, K.L. and Morgan, L.A., 1992, The track of the Yellowstone hot spot: volcanism, faulting, and uplift, in Link, P.K., Kuntz, M.A., and Platt, L.B., eds., Regional Geology of Eastern Idaho and Western Wyoming: Geological Society of America Memoir 179, 53 p.

Potter, S.L., 1991, Geologic characteristics of the Calvert ash bed, Ogallala Group (Miocene), western Kansas [M.S. thesis]: Hays, KS, Fort Hays State University, 86 p.

Qi, S.L., 2010, Digital map of the aquifer boundary of the High Plains aquifer in parts of Colorado, Kansas, Nebraska, New Mexico, Oklahoma, South Dakota, Texas, and Wyoming: U.S. Geological Survey Data Series 543.

Rasmussen, B. and Fletcher, I.R., 2010, Dating sedimentary rocks using in situ U-Pb geochronology of syneruptive zircon in ash-fall tuffs < $1 \mathrm{~mm}$ thick: Geology, v. 38, p. 299302.

Renne, P.R., Mundil, R., Balco, G., Min, K., and Ludwig, K.R., 2010, Joint determination of ${ }^{40}$ K decay constants and ${ }^{40} \mathrm{Ar}^{*} /{ }^{40} \mathrm{~K}$ for the Fish Canyon sanidine standard, and improved accuracy for ${ }^{40} \mathrm{Ar} /{ }^{39} \mathrm{Ar}$ geochronology: Geochimica et Cosmochimica Acta, v. 74, p. 53495367.

Riihimaki, C.A., Anderson, R.S., and Safran, E.B., 2007, Impact of rock uplift on rates of late Cenozoic Rocky Mountain river incision: Journal of Geophysical Research: Earth Surface, v. 112,15 p.

Rodgers, D.W., Hackett, W.R., and Ore, H.T., 1990, Extension of the Yellowstone Plateau, eastern Snake River Plain, Owyhee Plateau: Geology, v. 18, p. 1138-1141.

Rose, W.I., Riley, C.M. and Dartevelle, S., 2003, Sizes and shapes of 10-Ma distal fall pyroclasts in the Ogallala Group, Nebraska: The Journal of geology, v. 111, p. 115-124.

Roy, M., Kelley, S., Pazzaglia, F., Cather, S., and House, M., 2004, Middle Tertiary buoyancy modification and its relationship to rock exhumation, cooling, and subsequent extension at the eastern margin of the Colorado Plateau: Geology, v. 32, p. 925-928.

Santos, R.V., Souza, P.A., de Alvarenga, C.J.S., Dantas, E.L., Pimentel, M.M., de Oliveira, C.G. and de Araújo, L.M., 2006, Shrimp U-Pb zircon dating and palynology of bentonitic layers from the Permian Irati Formation, Paraná Basin, Brazil: Gondwana Research, v. 9, p. 456463.

Seni, S.J., 1980, Sand-body geometry and depositional systems, Ogallala Formation, Texas: Texas Bureau of Economic Geology Report of Investigations 105, 36 p.

Sheldon, N.D. and Tabor, N.J., 2009, Quantitative paleoenvironmental and paleoclimatic reconstruction using paleosols: Earth-Science Reviews, v. 95, p. 1-52.

Skinner, M.F. and Johnson, F.W., 1984, Tertiary stratigraphy and the Frick Collection of fossil vertebrates from north-central Nebraska: Bulletin of the American Museum of Natural History, v. 178, p. 215-368.

Sláma, J., Košler, J., Condon, D.J., Crowley, J.L., Gerdes, A., Hanchar, J.M., Horstwood, M.S.A., Morris, G.A., Nasdala, L., Norberg, N., Schaltegger, U., Schoene, B., Tubrett, M.N., and 
Whitehouse, M.J., 2008, Plešovice zircon-a new natural reference material for U-Pb and Hf isotopic microanalysis: Chemical Geology, v. 249, p. 1-35.

Smith, H.T.U., 1940, Geological studies in southwestern Kansas: Kansas Geological Survey, Bulletin 34, p. 1-212.

Smith, J.J., Layzell, A.L., Lukens, W.E., Morgan, M.L., Keller, S.M., Martin, R.A., and Fox, D.L., 2016, Getting to the bottom of the High Plains aquifer: new insights into the depositional history, stratigraphy, and paleoecology of the Cenozoic High Plains, in Morgan, M.L. and Keller, S.M., eds., Geological Society of America Field Guides (in press).

Smith, J. and Ludvigson, G., 2011, A Report to the Calvert Corporation on a Geologic Inspection of the Calvert Volcanic Ash Mine: Kansas Geological Survey, Open-File Report 2014-3, $5 \mathrm{p}$.

Smith, J., Ludvigson, G.A., Harlow, H., and Platt, B., 2014, Ogallala-High Plains aquifer special study phase III: Lithologic calibration of practical saturated thickness in the Ogallala-High Plains aquifer: Kansas Geological Survey, Open-File Report 2014-2, 9 p.

Smith, R.B. and Braile, L.W., 1993, Topographic signature, space-time evolution, and physical properties of the Yellowstone-Snake River Plain volcanic system: the Yellowstone hotspot, in Snoke, A.W., Steidtmann, J.R., and Roberts, S.M., eds., Geological Survey of Wyoming Memoir 5, p. 694-754.

Soller, D.R. and Reheis, M.C., 2004, Surficial materials in the conterminous United States: U.S. Geological Survey Open-File Report 03-275, scale 1:5,000,000.

Steward, D.R. and Allen, A.J., 2016, Peak groundwater depletion in the High Plains Aquifer, projections from 1930 to 2110: Agricultural Water Management, v. 170, p. 36-48.

Steward, D.R., Bruss, P.J., Yang, X., Staggenborg, S.A., Welch, S.M., and Apley, M.D., 2013, Tapping unsustainable groundwater stores for agricultural production in the High Plains Aquifer of Kansas, projections to 2110: Proceedings of the National Academy of Sciences, v. 110, p. E3477-E3486.

Stone, W.J., 1990, Natural recharge of the Ogallala aquifer through playas and other non-streamchannel settings, eastern New Mexico, in Gustavson, T.C., ed., Geologic Framework and Regional Hydrology: Upper Cenozoic Blackwater Draw and Ogallala Formations, Great Plains: Texas Bureau of Economic Geology Symposium Publication 6, p. 180-192.

Sweet, M.L., 1999, Interaction between aeolian, fluvial and playa environments in the Permian Upper Rotliegend Group, UK southern North Sea: Sedimentology, v. 46, p. 171-188.

Swineford, A, 1963, The Pearlette ash as a stratigraphic marker: Transactions of the Kansas Academy of Science, v. 66, p. 359-362.

Swineford, A., Frye, J.C., and Leonard, A.B., 1955, Petrography of the late Tertiary volcanic ash falls in the central Great Plains: Journal of Sedimentary Petrology, v. 25, p. 243-261.

Swineford, A., Leonard, A.B., and Frye, J.C., 1958, Petrology of the pisolitic limestone in the Great Plains: Kansas Geological Survey, Bulletin 130, pt. 2, p. 97-116.

Swinehart, J.B., 1974, Ogallala stratigraphy of southwest Nebraska: a proposal: Nebraska Academy of Science Program, p. 36-37.

Swinehart, J.B., Souders, V.L., DeGraw, H.M., and Diffendal R.F., Jr., 1985, Cenozoic paleogeography of western Nebraska, in Flores, R.M. and Kaplan, S.S., eds., Cenozoic Paleogeography of West-Central United States: Rocky Mountain Paleogeography Symposium, v.3, p. 209-229.

Tallan, M.E., 1978, Systematics and biostratigraphy of the early Hemphillian Bemis local fauna, Ellis County, Kansas [M.S. thesis]: Hays, KS, Fort Hays State University, 36 p. 
Thomasson, J.R., 1979, Late Cenozoic grasses and other angiosperms from Kansas, Nebraska, and Colorado: Biostratigraphy and relationships to living taxa: Kansas Geological Survey, Bulletin 218, 68 p.

Thomasson, J.R., 1990, Fossil plants from the late Miocene Ogallala Formation of central North America: possible paleoenvironmental and biostratigraphic significance, in Gustavson, T.C., ed., Geologic Framework and Regional Hydrology: Upper Cenozoic Blackwater Draw and Ogallala Formations, Great Plains: Texas Bureau of Economic Geology Symposium Publication 6, p. 99-114.

Trimble, D.E., 1980, Cenozoic tectonic history of the Great Plains contrasted with that of the Southern Rocky Mountains: a synthesis: The Mountain Geologist, v. 17, p. 59-69.

Turner, E., Smith, J.J., Ludvigson, G.A., Layzell, A.L., and Möller, A., 2015, Maximum depositional age constraints from U-Pb dating of zircons in Cenozoic deposits of the High Plains Aquifer, southwestern Kansas: Geological Society of America Abstracts with Programs, v. 47, p. 801.

van Dijk, W.M., Densmore, A.L., Singh, A., Gupta, S., Sinha, R., Mason, P.J., Joshi, S.K., Nayak, N., Kumar, M., Shekhar, S., Kumar, D., and Rai, S.P., 2016, Linking the morphology of fluvial fan systems to aquifer stratigraphy in the Sutlej-Yamuna plain of northwest India: Journal of Geophysical Research: Earth Surface, v. 121, p. 201-222.

Vermeesch, P., 2012, On the visualisation of detrital age distributions: Chemical Geology, v. 312313, p. 190-194.

Wayne, W.J., Aber, J.S., Agard, S.S., Bergantino, R.N., Bluemle, J.P., Coates, D.A., Cooley, M.E., Madole, R.F., Martin, J.E., Mears, B., Jr., Morrison, R.B., and Sutherland, W.M., 1991, Quaternary geology of the Northern Great Plains, in Morrison, R.B., ed., The Geology of North America, v. K-2: Quaternary Nonglacial Geology: Conterminous U.S., p. 441-476.

Weeks, J.B. and Gutentag, E.D., 1981, Bedrock geology, altitude of base, and 1980 saturated thickness of the high plains aquifer in parts of Colorado, Kansas, Nebraska, New Mexico, Oklahoma, South Dakota, Texas, and Wyoming: U.S. Geological Survey Hydrologic Investigations Atlas HA-648, scale 1:2,500,000, 2 sheets.

Weissmann, G.S., Hartley, A.J., Nichols, G.J., Scuderi, L.A., Olson, M., Buehler, H., and Banteah, R., 2010, Fluvial form in modern continental sedimentary basins: Distributive fluvial systems: Geology, v. 38, p. 39-42.

Wilson, B., MacFarlane, P.A., Young, D.P., and Sleezer, R., 2009, High Plains aquifer bedrock isolines: accessed 24 May 2016 <http://www.kansasgis.org/catalog/index.cfm>.

Wobus, C.W., Tucker, G.E., and Anderson, R.S., 2010, Does climate change create distinctive patterns of landscape incision? Journal of Geophysical Research: Earth Surface, v. 115, 12 p.

Wotzlaw, J.F., Schaltegger, U., Frick, D.A., Dungan, M.A., Gerdes, A., and Günther, D., 2013, Tracking the evolution of large-volume silicic magma reservoirs from assembly to supereruption: Geology, v. 41, p. 867-870.

Zakrzewski, R.J., 1990, Biostratigraphy of fossil mammals from the Ogallala (Miocene) of northcentral Kansas, in Gustavson, T.C., ed., Geologic Framework and Regional Hydrology: Upper Cenozoic Blackwater Draw and Ogallala Formations, Great Plains: Texas Bureau of Economic Geology Symposium Publication 6, p. 98.

Zeigler, K.E., Petronis, M.S., Smith, J.J., Ludvigson, G.A., and Doveton, J., 2012, The Neogene Ogallala Formation in southwestern Kansas and northeastern New Mexico: Preliminary 
magnetostratigraphic analyses for the High Plains-Ogallala Drilling Program: AGU Fall Meeting Abstracts, v. 1, p. 1032.

Zeller, D.E., ed., 1968, The stratigraphic succession in Kansas: Kansas Geological Survey, Bulletin 189, $81 \mathrm{p}$. 


\section{FIGURES}

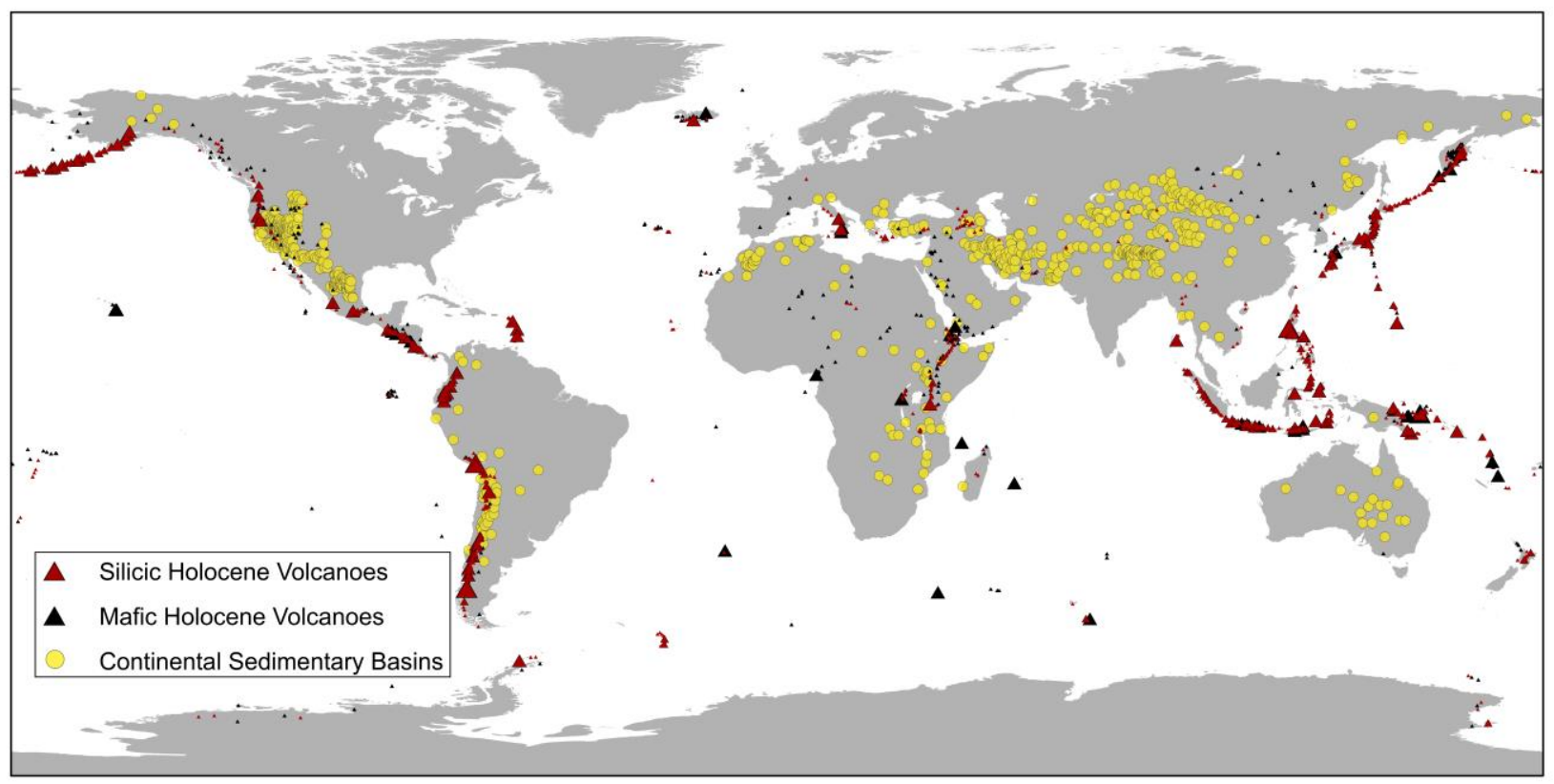

Figure 1. Spatial distribution of modern non-marine continental sedimentary basins (Weissmann et al., 2010) compared to Holocene subaerial volcanoes (Global Volcanism Program, 2013) scaled by size according to their ash-bearing potential using the model of Mastin et al. (2009a,b). Many continental clastic basins, for instance in North America, are hundreds to thousands of kilometers from active volcanic arcs, rifts, and hot spots. These basins potentially preserve volcanogenic zircon from volcanic ash distributed in large eruptions. When recognized, zircon-bearing volcanic ash can provide valuable age information in strata that are poor in other common chronological and correlative means, such as marine fossils. 

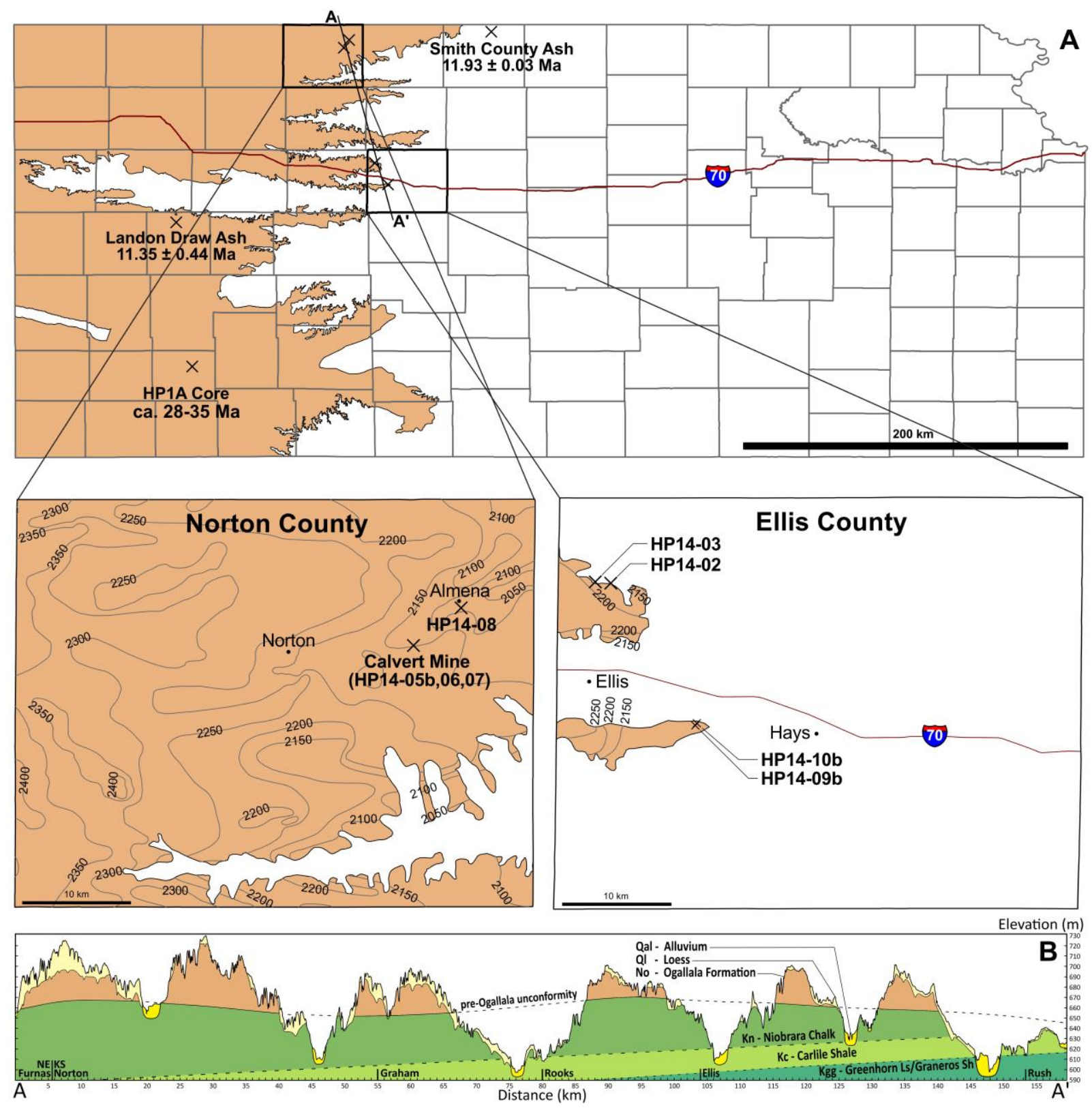

Figure 2. (A) The Ogallala Formation and associated Ogallala-High Plains aquifer serve as the primary water source for irrigation and domestic water consumption in the High Plains of the central United States. The subsurface and exposed extent of the Ogallala Formation in western Kansas is modified from Qi (2010) in order to exclude hydrologically connected Quaternary units of the Ogallala-High Plains aquifer using maps by Moore et al. (1951) and Zeller (1968). PreOgallala topography is revealed by structure contours $(\mathrm{ft})$ of the base of the Ogallala Formation 
(Wilson et al., 2009). Existing absolute dates are sparse: chemical fingerprinting of an ash from Smith County most closely matches the $11.93 \pm 0.03$ Ma Ibex Hollow ash (Ludvigson et al., 2009). This ash plots outside of the currently mapped extent of the Ogallala Formation, indicating that revisions to lithologic mapping criteria are needed (Ludvigson et al., 2009). A single zircon from an ash at Landon Draw yields an LA-ICP-MS date of $11.35 \pm 0.44 \mathrm{Ma}$ (personal communication from analyst Brian Sitek, 2014). Sedimentological characteristics and U-Pb zircon data from the HP1A core indicates that parts of southwestern Kansas mapped as Ogallala Formation may be a previously unrecognized equivalent of the Paleogene White River Group (Smith et al., 2014; Turner et al., 2015; Smith et al., 2016). (B) Cross section showing depositional and cross-cutting relations between units exposed in western Kansas inferred from existing maps (Frye and Leonard, 1949; Neuhauser and Pool, 1988). Location and dip of the Niobrara-Carlile and Carlile-Greenhorn contact is approximate and inferred from map M-118 by the Kansas Geological Survey (2008). The Ogallala basal unconformity is modified from smoothed regional-scale structure contours by Weeks and Gutentag (1981) and Cederstrand and Becker (1998). All contacts except CarlileGreenhorn are unconformable. Vertical exaggeration is $\sim 150$. 


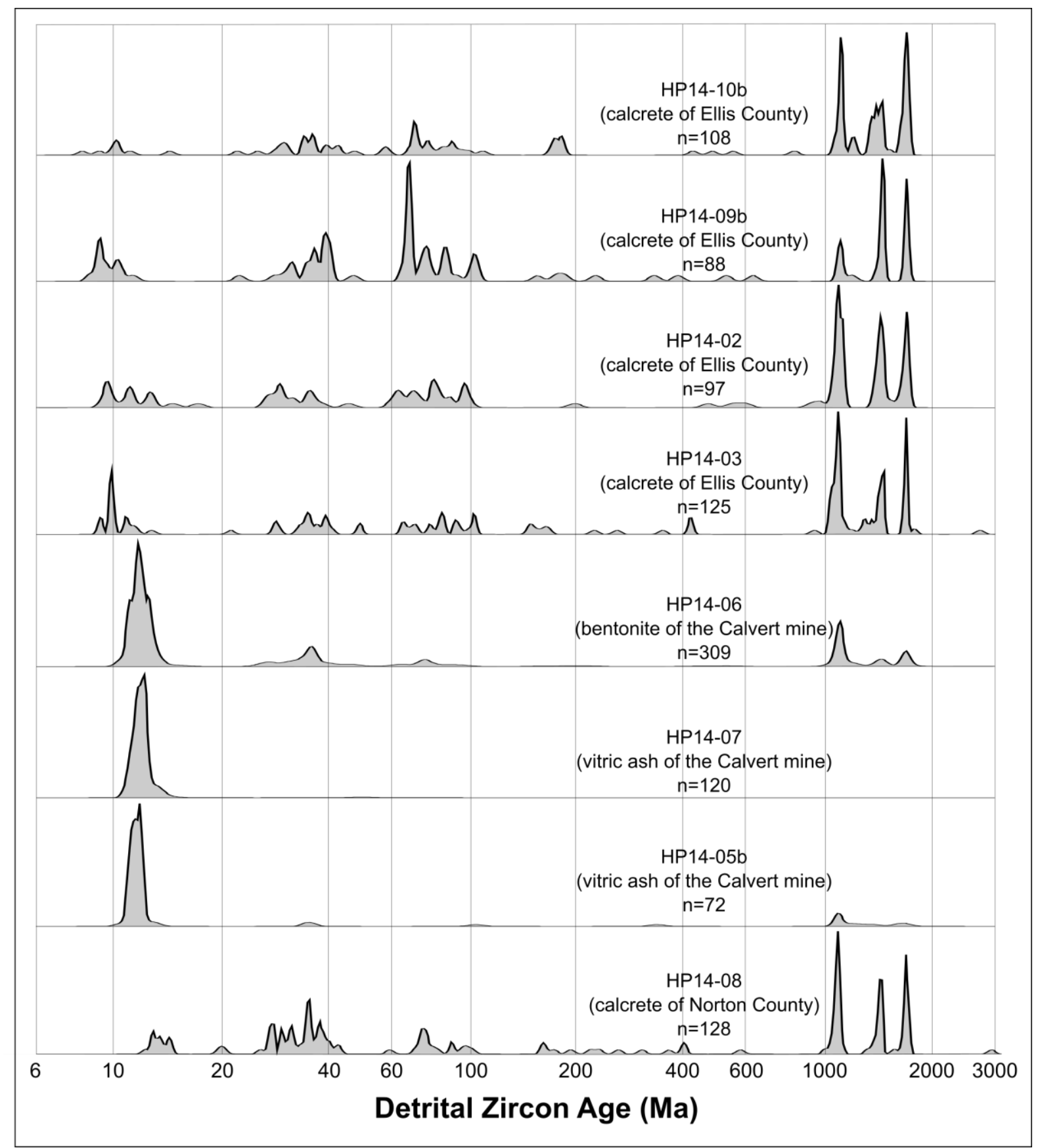

Figure 3. Kernel density plots based on ${ }^{206} \mathrm{~Pb} /{ }^{238} \mathrm{U}$ ages $(<850 \mathrm{Ma})$ and ${ }^{207} \mathrm{~Pb} /{ }^{206} \mathrm{~Pb}$ ages $(\geq 850$ Ma) constructed with DensityPlotter (Vermeesch, 2012). Calcretes contain abundant volcanogenic zircons, as well as Miocene to Archean detrital grains. Norton County vitric ashes and bentonites derived from those ashes are dominated by volcanogenic middle Miocene grains. Analyses with normalized discordance $\left({ }^{207} \mathrm{~Pb} /{ }^{235} \mathrm{U}_{\text {age }}-{ }^{206} \mathrm{~Pb} /{ }^{238} \mathrm{U}_{\text {age }}\right) /\left({ }^{207} \mathrm{~Pb} /{ }^{235} \mathrm{U}_{2 \sigma}\right.$ age uncertainty $)>5$ were omitted. 

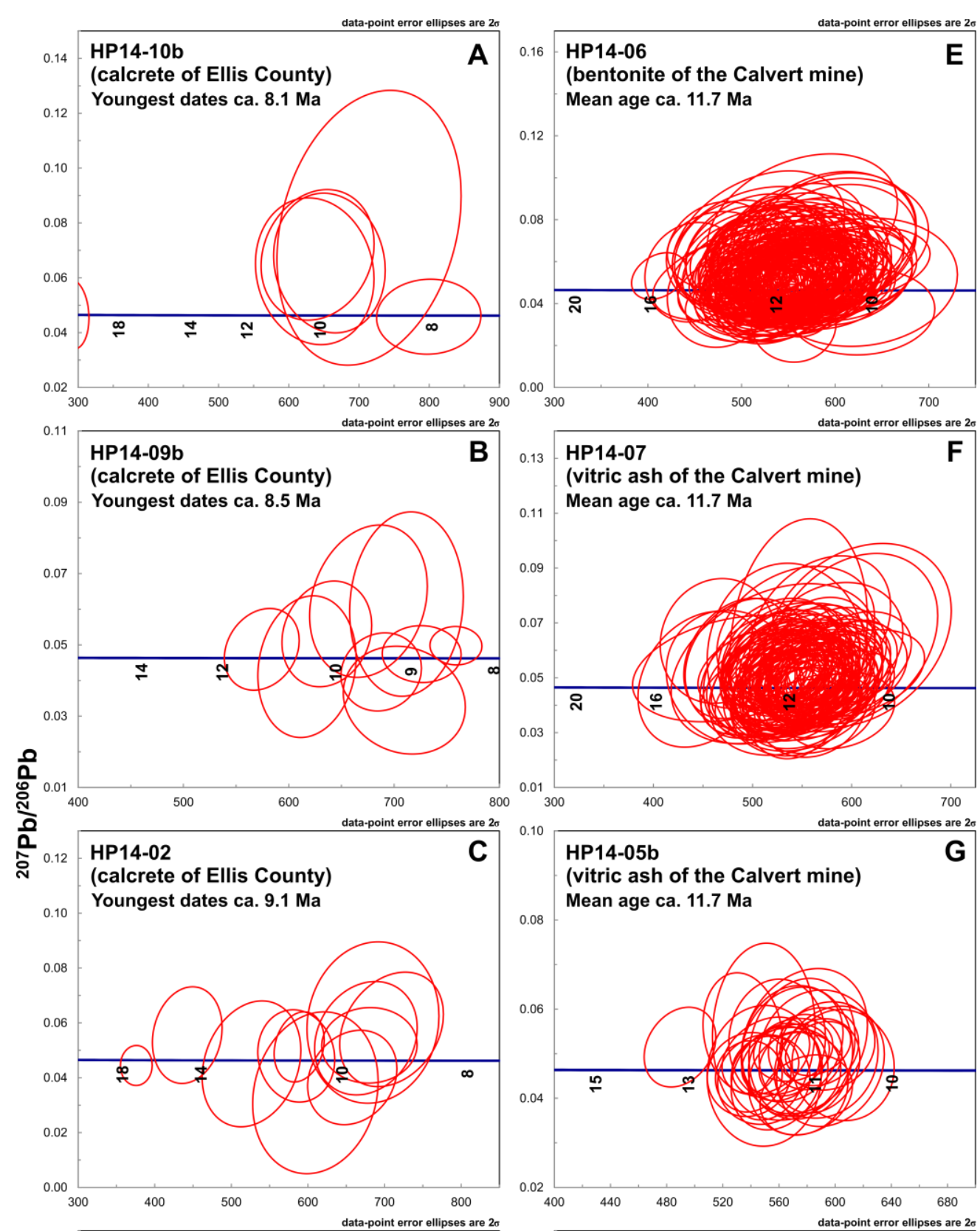

\begin{tabular}{l|l|l}
0.13 & $\begin{array}{l}\text { HP14-07 } \\
\text { (vitric ash of the Calvert mine) } \\
\text { Mean age ca. 11.7 Ma }\end{array}$ \\
\hline
\end{tabular}

ses are
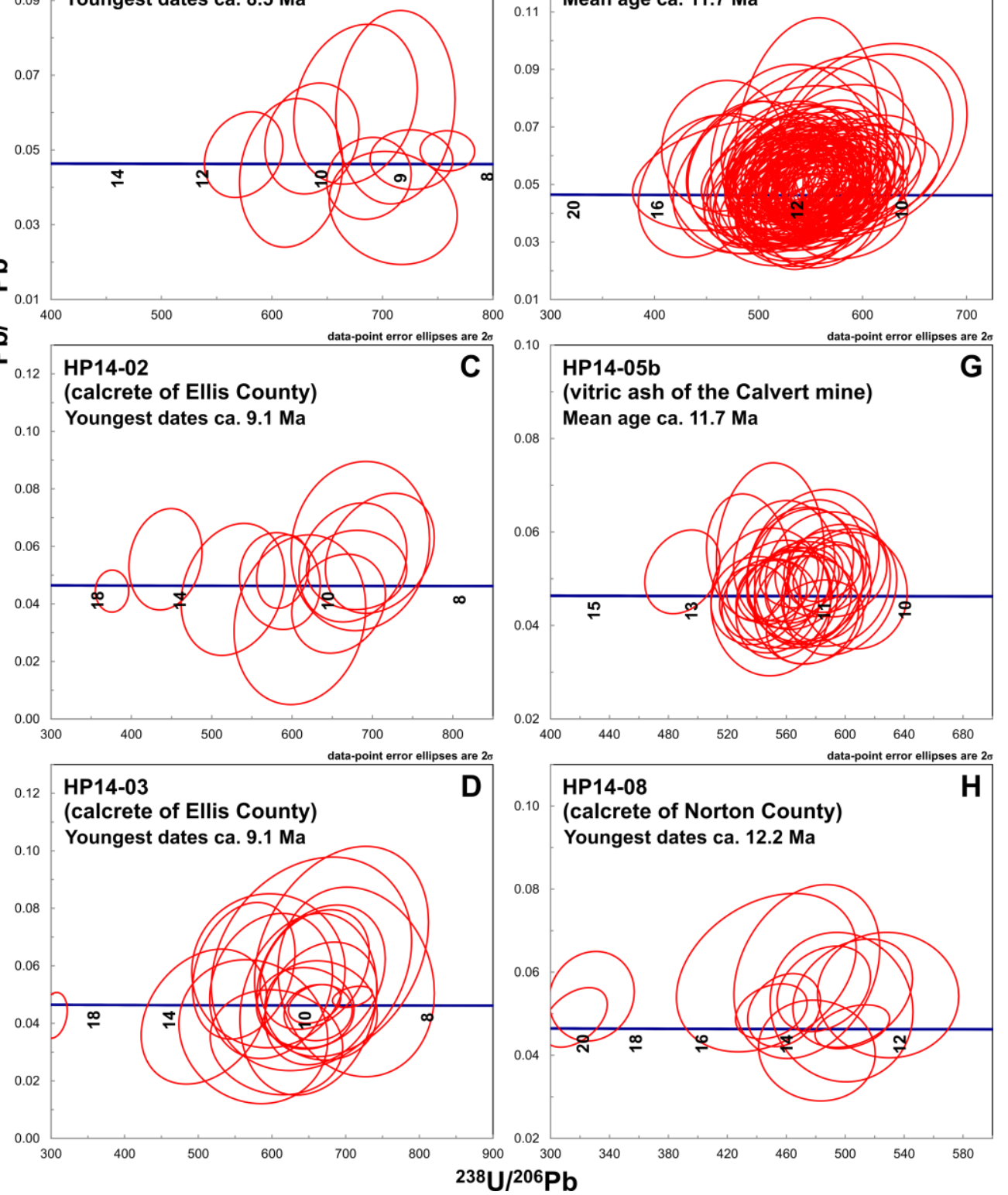
Figure 4. $\mathrm{U}-\mathrm{Pb}$ concordia diagrams depicting the youngest concordant dates from each dated sample. Ellis County calcretes include grains as young as 8.1-9.1 Ma, Norton County ashes and bentonites are each dominated by an 11.7 Ma population, and a Norton County calcrete includes grains as young as $~ 12.2 \mathrm{Ma}$. Full detrital age spectra are presented in Figure 3. Analyses with normalized discordance $\left({ }^{207} \mathrm{~Pb} /{ }^{235} \mathrm{U}_{\text {age }}-{ }^{206} \mathrm{~Pb} /{ }^{238} \mathrm{U}_{\text {age }}\right) /\left({ }^{207} \mathrm{~Pb} /{ }^{235} \mathrm{U}_{2 \sigma}\right.$ age uncertainty $)>1.2$ were omitted for clarity. 


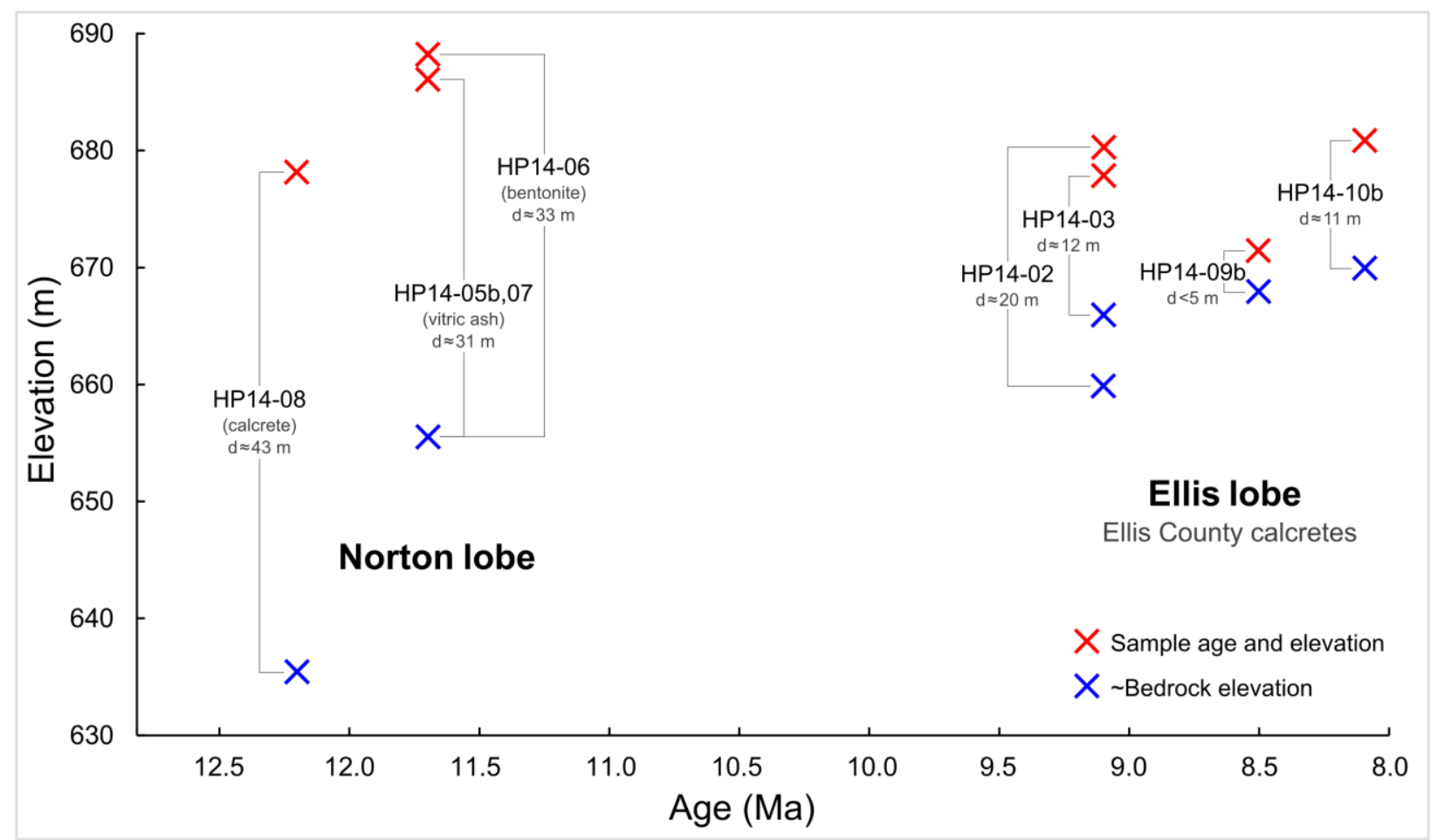

Figure 5. Bedrock topography (adapted from Wilson et al., 2009) governed the timing of Ogallala Formation deposition in northwestern Kansas and locally within Norton and Ellis counties. Deposition in the vicinity of Norton County began prior to $12.2 \mathrm{Ma}$ and aggraded to $\sim 690 \mathrm{~m}$ in elevation by ca. 11.7 Ma. Aggradation in the vicinity of Ellis County began shortly before 9 Ma and aggraded to $\sim 680 \mathrm{~m}$ in elevation ca. $8.1 \mathrm{Ma}$ or later. 


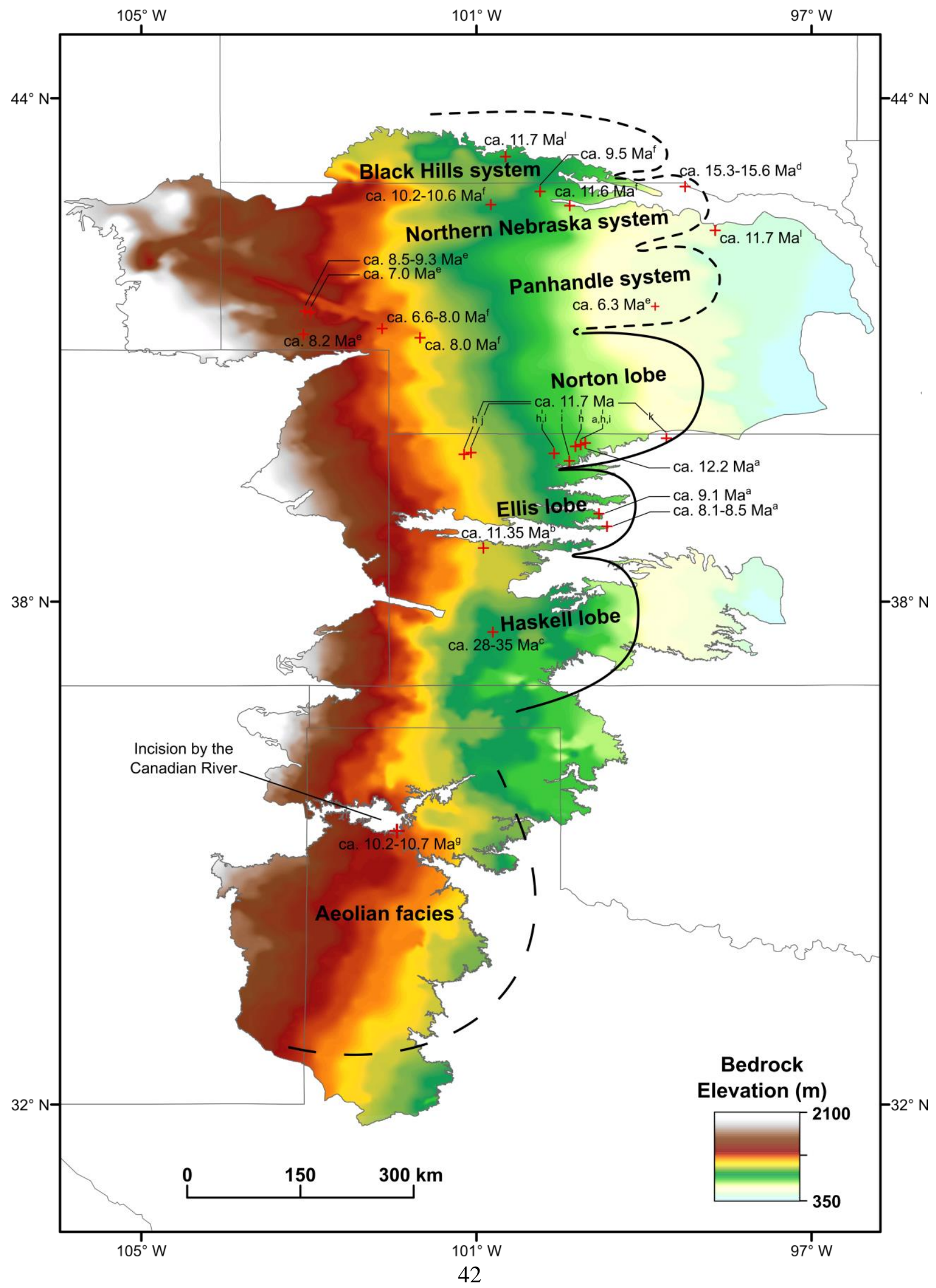


Figure 6. The spatial and temporal architecture of the Ogallala Formation, with bedrock elevations illustrated over its regional extent and inferred depositional ages marked in red, is consistent with its aggradation as a series of diachronous fluvial lobes. The middle Miocene Norton lobe aggraded on the northern flank of a central Kansas bedrock ridge ca. 11-13 Ma, followed by the late Miocene Ellis lobe over the inverted topography of the central Kansas ridge ca. 8-10 Ma. Eocene-Oligocene deposits of southwestern Kansas (Smith et al., 2014; Turner et al., 2015; Smith et al., 2016) potentially constitute an inferred Haskell lobe. Kansas lobe geometry is based on bedrock topography and geochronology presented here. To the north of Kansas, three Nebraska paleodrainage systems inferred by Skinner and Johnson (1984) are plotted as fluvial lobes (small dashes). The Ogallala Formation south of the Canadian River consists of a sheet of aeolian deposits (dashed) overlying fluvial channel fills and bedrock interfluves (Gustavson and Winkler, 1988; Holliday, 1991).

Bedrock topography is revealed by a DEM modified from the bedrock structure contours of Weeks and Gutentag (1981) and Cederstrand and Becker (1998). This late Cenozoic surface controlled deposition of the Ogallala Formation and associated units both locally (Fig. 5) and regionally. Geographic extent of the Cenozoic continental clastic units associated with the Ogallala-High Plains aquifer is given by the boundary of Qi (2010).

Plotted ages for the undated Ashfall Fossil Beds, Mission Pit (Famoso and Pagnac, 2011), and Smith County ashes (Ludvigson et al., 2009) are revised to ca. 11.7 Ma because of their shared correlation with the Ibex Hollow ash and by extension, the Calvert ash dated as part of this study. Dates are sourced from: a, this study; b, personal communication from analyst Brian Sitek, 2014 (zircon LA-ICP-MS); c, Turner et al., 2015; Smith et al., 2016 (zircon LA-ICP-MS); d, Field et al., 2015 (zircon LA-ICP-MS); e, Boellstorff, 1976 (glass fission-track); f, Skinner and Johnson, 
1984 (glass fission-track); g, Cepeda and Perkins, 2006 (glass K-Ar). Plotted yet undated ashes are correlated to dated beds by ash petrography unless otherwise specified: h, Potter, 1991; i, Carey et al., 1952; j, Swineford et al., 1955; k, Ludvigson et al., 2009 (chemical fingerprinting); 1, Famoso and Pagnac, 2011. 


\section{APPENDICES}

\section{Appendix A: Annotated Outcrop Photographs}

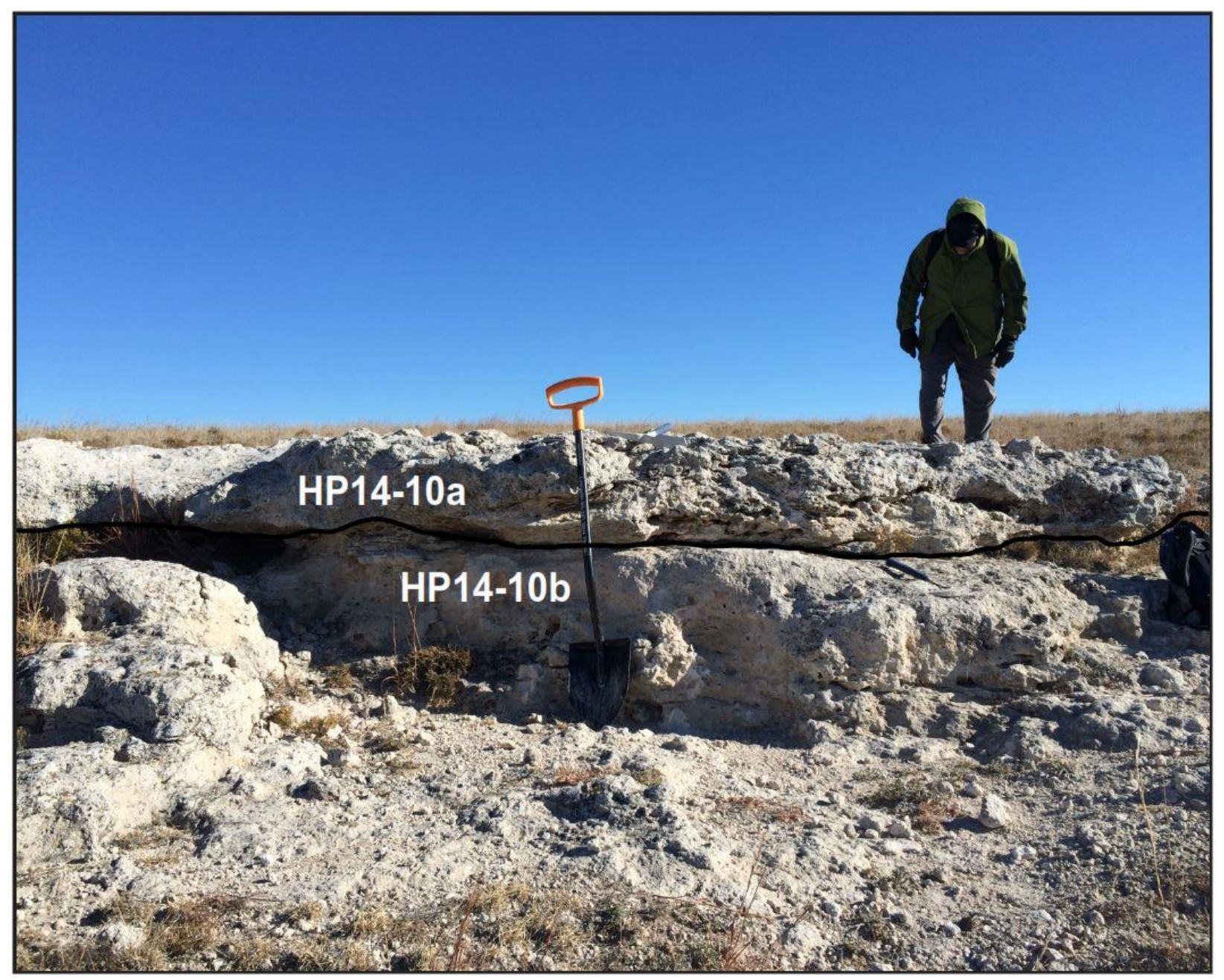

Figure 7. Calcrete near the Bemis Local Fauna locality of Tallan (1978) in west-central Ellis

County. Both HP14-10b and HP14-10a (not dated) include sand and pebbles. 


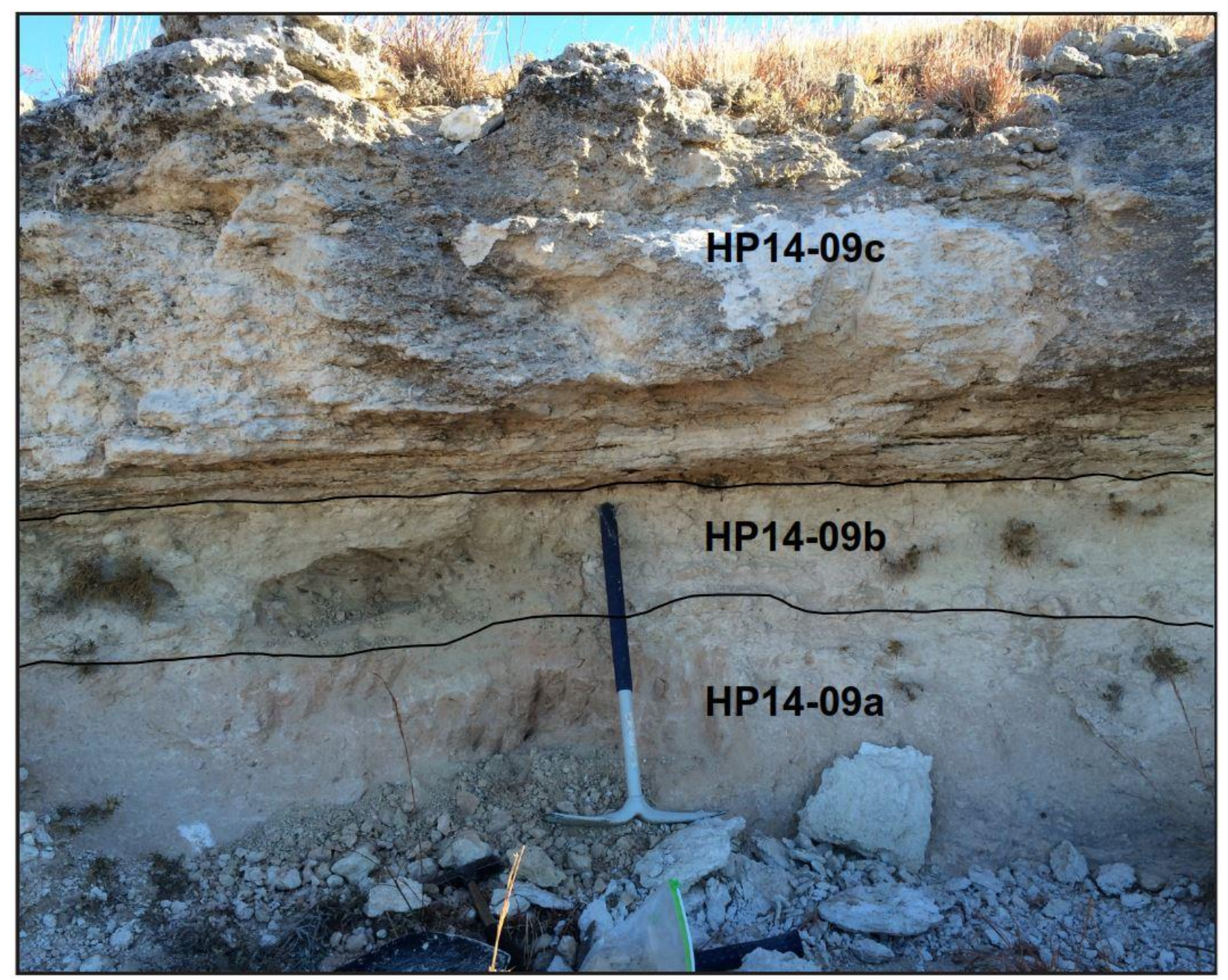

Figure 8. Calcrete near the Bemis Local Fauna locality (Tallan, 1978; Thomasson, 1979) in westcentral Ellis County. Units are distinguished primarily by color and weathering profile. 


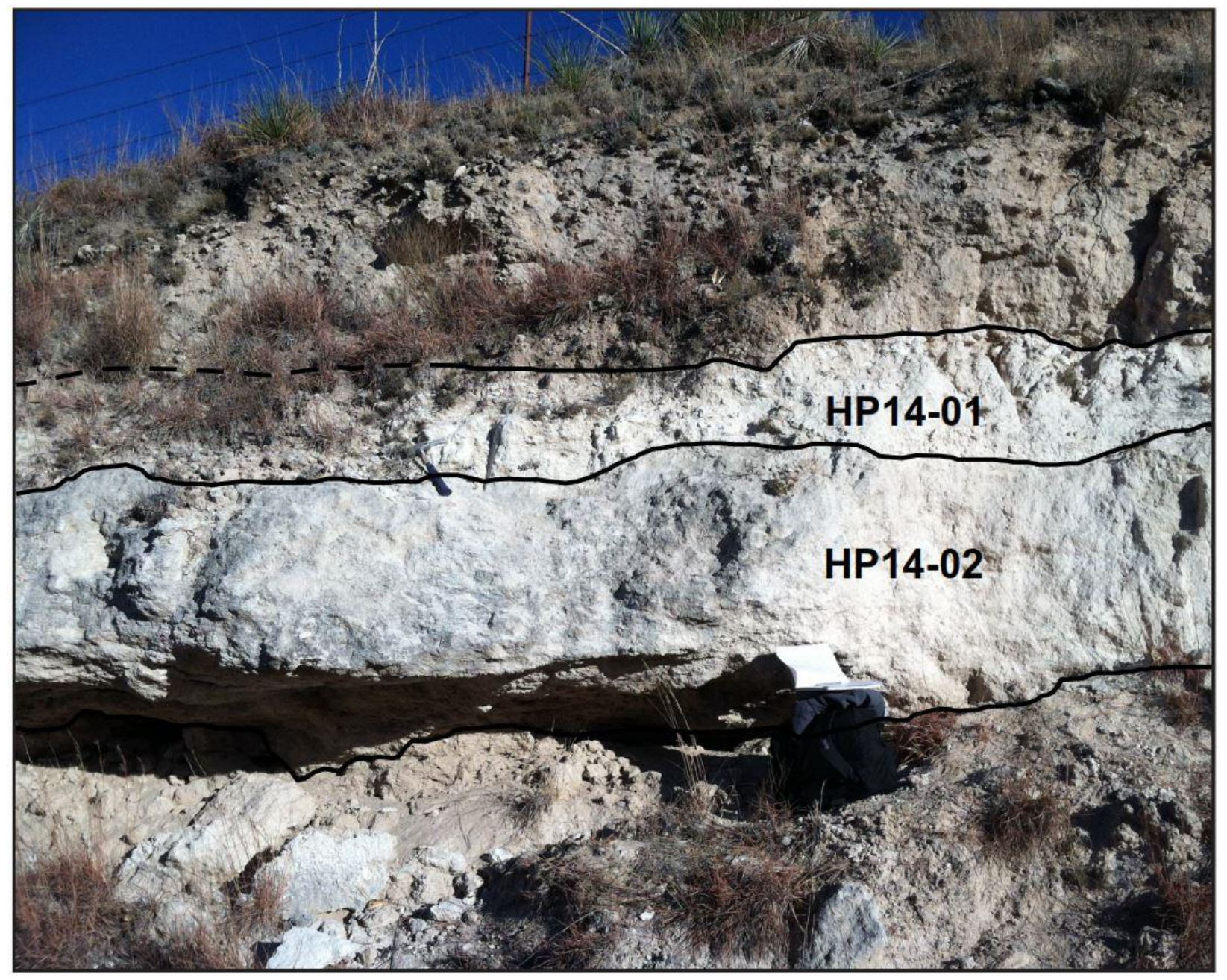

Figure 9. Calcrete in a roadcut along $130^{\text {th }}$ Ave previously described by Thomasson (1979). The upper unit (HP14-01; not dated) contains gastropod casts and a finer-grained clastic assemblage than the lower unit (HP14-02). 


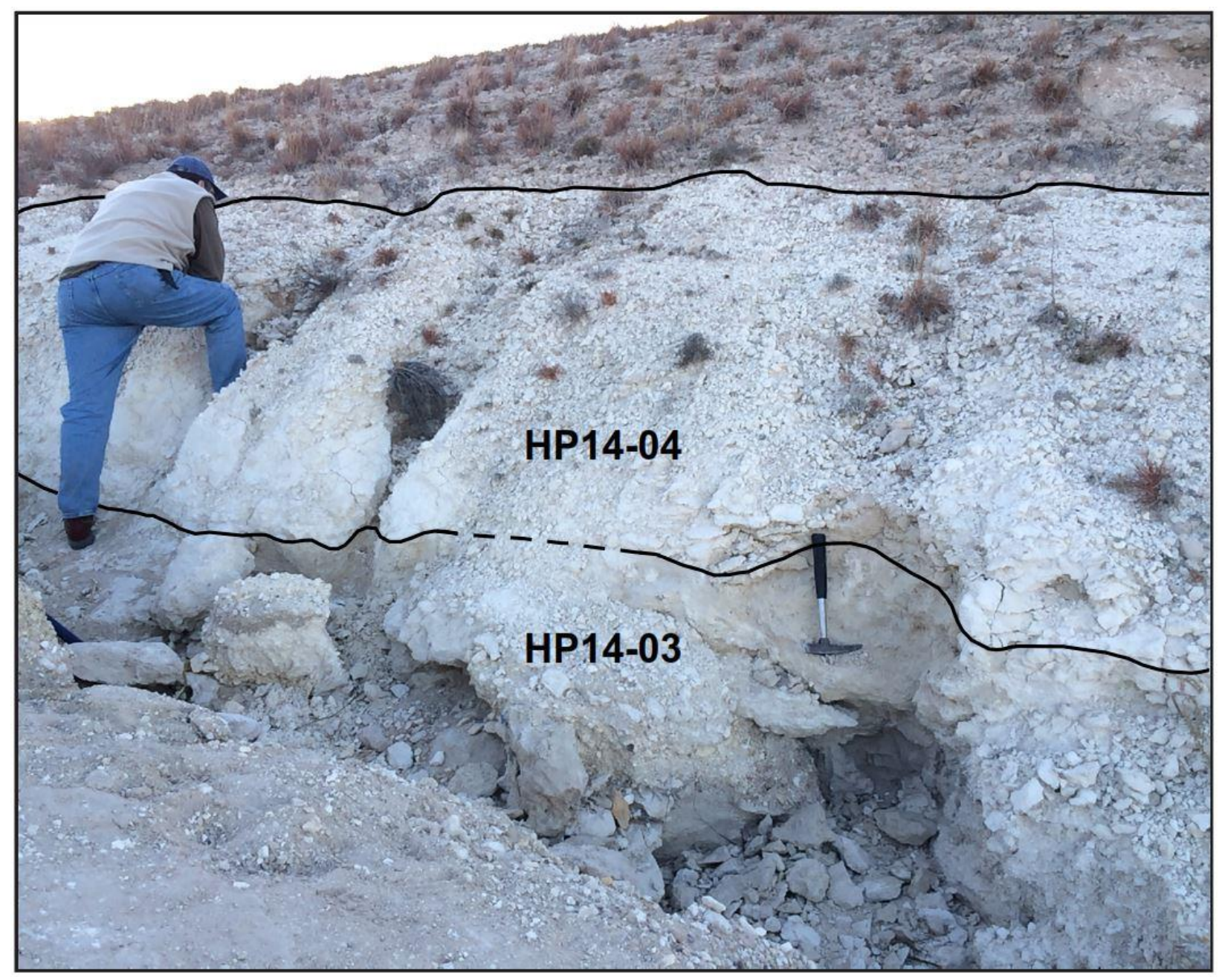

Figure 10. Calcrete in a roadcut along 120th Ave. The lower unit (HP14-03) includes a larger, coarser-grained assemblage of sand and pebbles than the upper unit (HP14-04; not dated). 


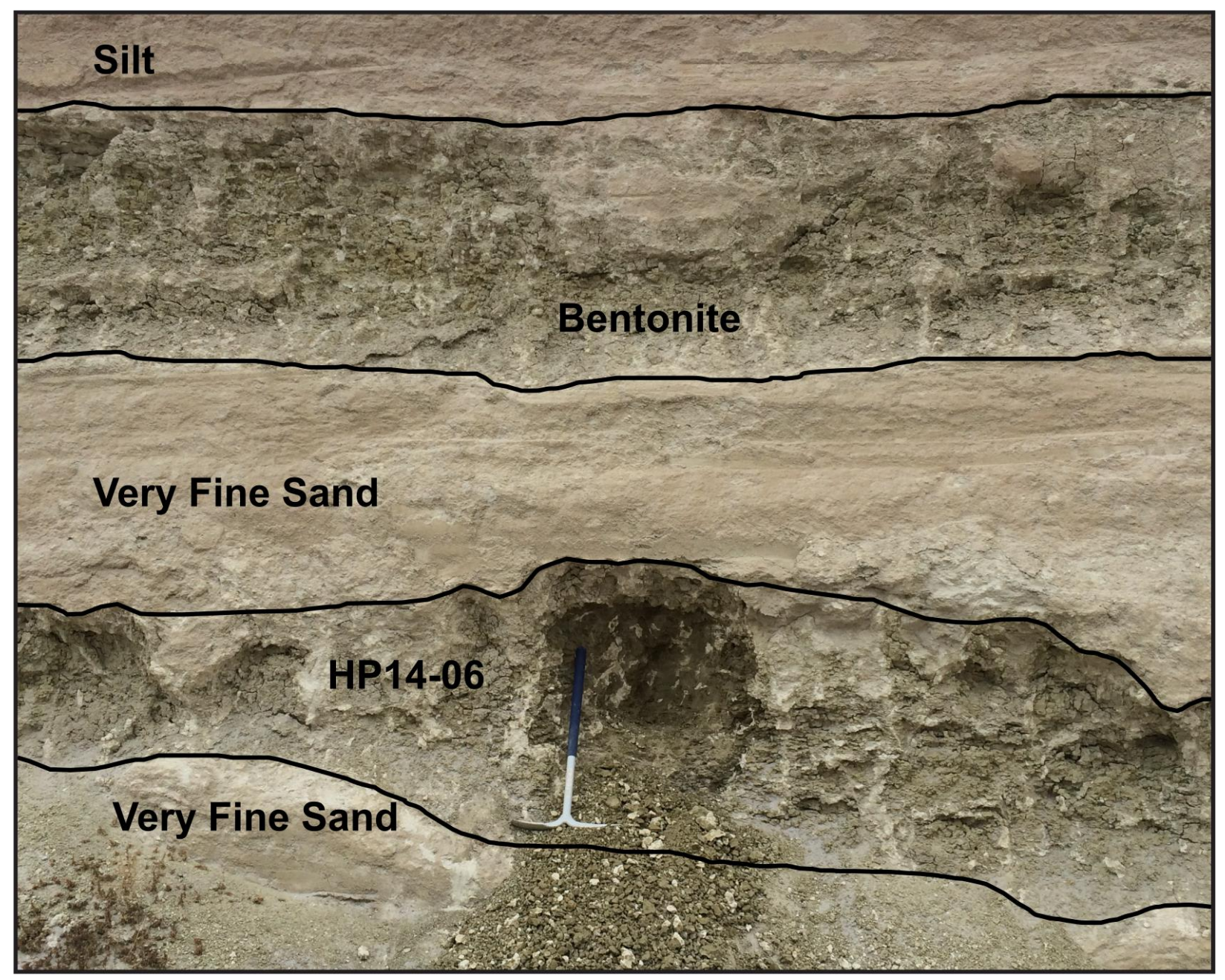

Figure 11. Bentonite paleosols (HP14-06) exposed at the Calvert volcanic ash mine are composed of green montmorillonite (Carey et al., 1952; Frye et al., 1956) and contain abundant rhizoliths. 


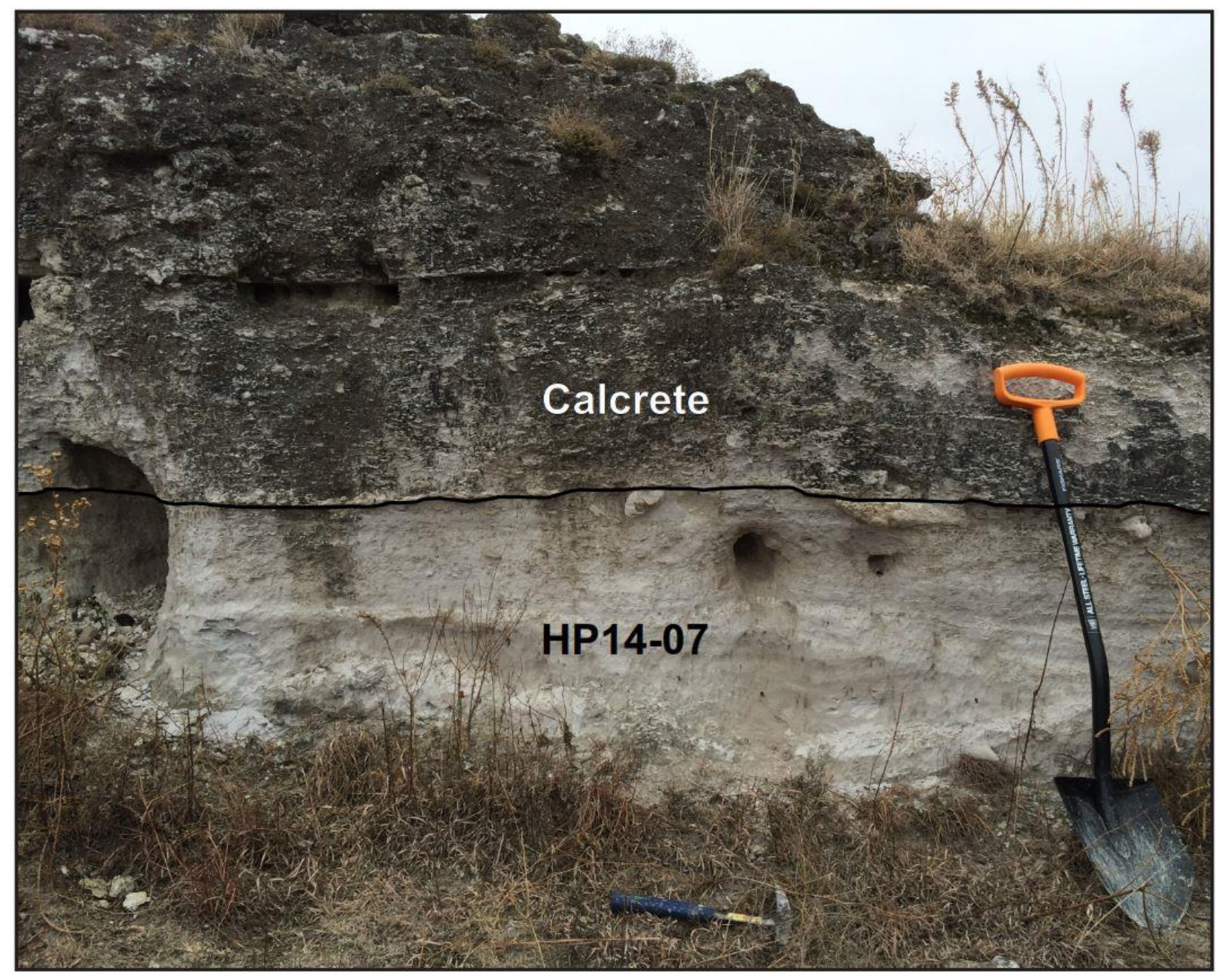

Figure 12. Fine-grained vitric ash from an abandoned face of the Calvert volcanic ash mine. 


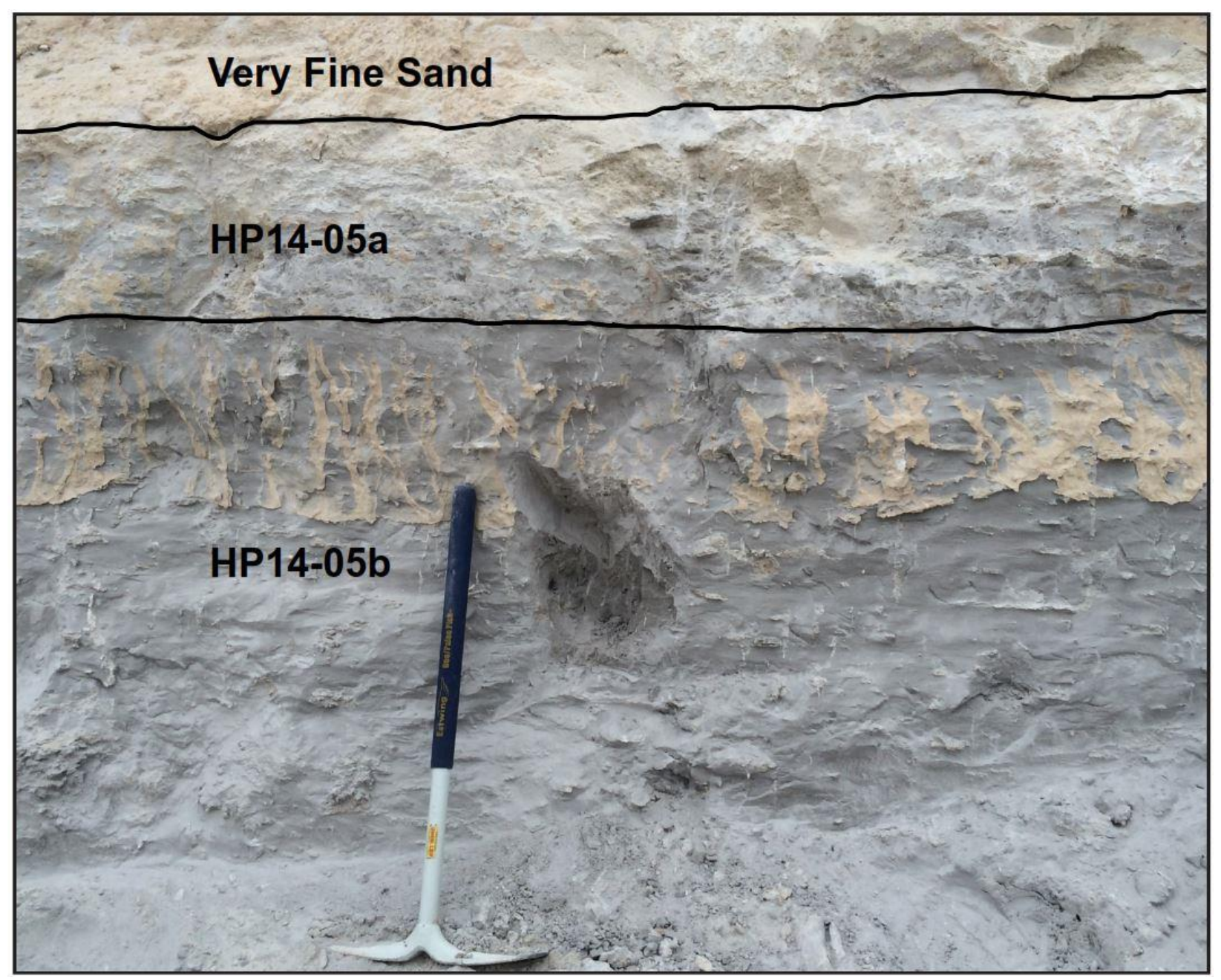

Figure 13. Fine-grained vitric ash from the Calvert volcanic ash mine. HP14-05b is a massively bedded and clean vitric ash. HP14-05a (not dated) is a finely laminated vitric ash that contains calcrete nodules and poorly sorted sand. 


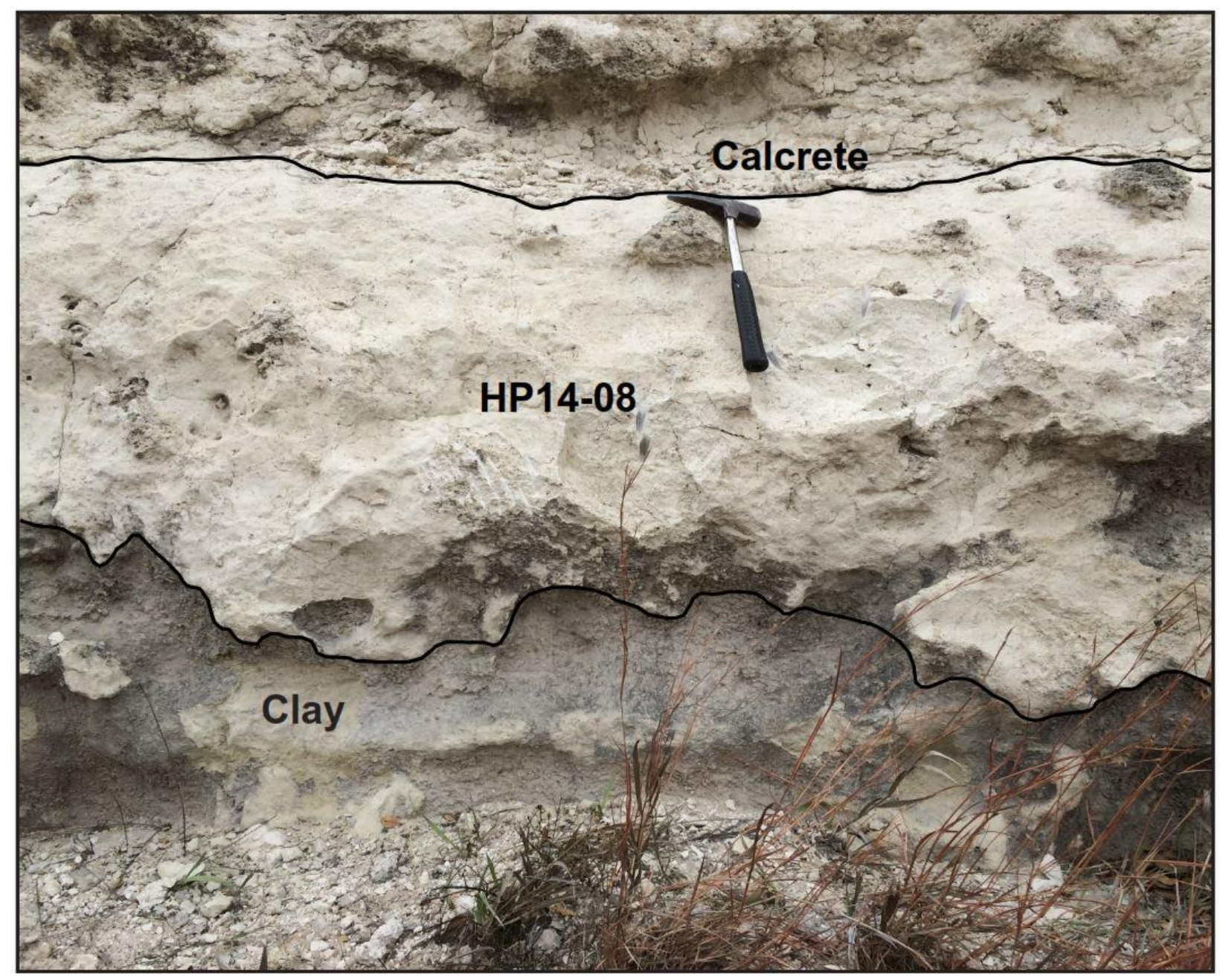

Figure 14. Calcrete in a roadcut along US Route 383 near the town of Almena that contains abundant rhizoliths. The upper calcrete is defined by its thin bedding planes and reduced resistance to weathering. 
Appendix B: LA-ICP-MS Metadata

\begin{tabular}{|c|c|}
\hline Laboratory \& Sample Preparation & \\
\hline Laboratory name & $\begin{array}{l}\text { KU Geology Isotope Geochemistry } \\
\text { Laboratories }\end{array}$ \\
\hline Sample type/mineral & Zircon \\
\hline Sample preparation & $\begin{array}{l}\text { Conventional mineral separation, tape } \\
\text { mount }\end{array}$ \\
\hline \multicolumn{2}{|l|}{ Laser Ablation System } \\
\hline Make, Model \& type & $\begin{array}{l}\text { ArF excimer } 193 \mathrm{~nm} \text {, Photon Machines } \\
\text { Analyte G2, ATLEX } 300\end{array}$ \\
\hline Ablation cell \& volume & Helex 2, two-volume cell \\
\hline Laser wavelength (nm) & 193 \\
\hline Pulse width & $5 \mathrm{~ns}$ \\
\hline Fluence & $2 \mathrm{~J} / \mathrm{cm}^{2}$ \\
\hline Repetition rate & $10 \mathrm{~Hz}$ \\
\hline Spot diameter (nominal/actual) & $20 / 20 \mu \mathrm{m}$ \\
\hline Sampling mode/pattern & Single spot \\
\hline Carrier gas (1/min) & $\mathrm{He}, 1.01 ; \mathrm{Ar}, 1.1$ \\
\hline Ablation duration (secs) & 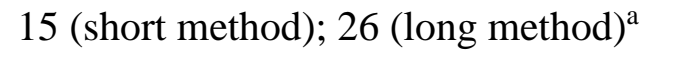 \\
\hline Cell carrier gas flow & $1.1 \mathrm{l} / \mathrm{min}$ \\
\hline \multicolumn{2}{|l|}{ ICP-MS Instrument } \\
\hline Make, Model \& type & $\begin{array}{l}\text { Thermo Element } 2 \text { magnetic sector field } \\
\text { ICP-MS }\end{array}$ \\
\hline Sample introduction & Ablation aerosol \\
\hline RF power & $1100 \mathrm{~W}$ \\
\hline Make-up gas flow & Ar, $1.11 / \mathrm{min}$ \\
\hline Sampling depth & $\sim 15 \mu \mathrm{m}$ \\
\hline Detection system & Single detector, counting $\&$ analog \\
\hline Masses measured & ${ }^{206} \mathrm{~Pb},{ }^{207} \mathrm{~Pb},{ }^{208} \mathrm{~Pb},{ }^{232} \mathrm{Th},{ }^{238} \mathrm{U}$ \\
\hline Integration time per peak (ms) & $1-6$ (short); 1-5 (long) \\
\hline Total integration time per reading (secs) & 7-13 (short); 8-23 (long) \\
\hline Total method time & 23 (short); 42 (long) \\
\hline Sensitivity/Efficiency & $\sim 0.1 \% \mathrm{U}, \mathrm{GJ}-1$ \\
\hline IC Dead time (ns) & 4 \\
\hline $\mathrm{UO}+\mathrm{U}+(\%)$ & $<0.2$ \\
\hline${ }^{238} \mathrm{U}+/{ }^{232} \mathrm{Th}+$ & 0.70 \\
\hline
\end{tabular}




\begin{tabular}{|c|c|}
\hline Data Processing & \\
\hline Gas blank (s) & 9 (short); 21 (long) \\
\hline Calibration strategy & $\begin{array}{l}\text { GJ-1 used as primary reference material, } \\
\text { Plešovice, Peixe, and Fish Canyon Tuff } \\
\text { used as secondary/validation materials }\end{array}$ \\
\hline Reference Material info & $\begin{array}{l}\text { NIST } 612 \text { (Jochum et al., 2011) } \\
\text { GJ-1 (Jackson et al., 2004) } \\
\text { Plešovice (Horstwood et al., 2016) } \\
\text { Peixe (G. Gehrels, unpublished data) } \\
\text { Fish Canyon Tuff (Wotzlaw et al., 2013) }\end{array}$ \\
\hline $\begin{array}{l}\text { Data processing package used/Correction for } \\
\text { LIEF }\end{array}$ & $\begin{array}{l}\text { IGOR PRO, Iolite } 2.5 \text {. LIEF correction } \\
\text { assumes reference material and samples } \\
\text { behave identically }\end{array}$ \\
\hline Mass discrimination & $\begin{array}{l}\text { IGOR PRO, Iolite 2.5. Correction assumes } \\
\text { reference material and samples behave } \\
\text { identically }\end{array}$ \\
\hline $\begin{array}{l}\text { Common-Pb correction, composition and } \\
\text { uncertainty }\end{array}$ & $\begin{array}{l}\text { No common- } \mathrm{Pb} \text { correction applied to the } \\
\text { data. }\end{array}$ \\
\hline Uncertainty level \& propagation & $\begin{array}{l}\text { Age uncertainties are reported at } \pm 2 \mathrm{~s} \\
\text { absolute, propagation is by quadratic } \\
\text { addition, following Paton et al. (2010) }\end{array}$ \\
\hline Reproducibility & $\begin{array}{l}\sim 0.7 \% \text { and } 1.8 \% \text { in replicate measurements } \\
\text { of the Fish Canyon Tuff and Plešovice, } \\
\text { respectively }\end{array}$ \\
\hline Quality control/Validation & $\begin{array}{l}\text { Peixe, Plešovice, and Fish Canyon Tuff } \\
\text { (see Table } \mathrm{C} 2 \text { for details) }\end{array}$ \\
\hline
\end{tabular}

${ }^{a}$ An initial ICP-MS method file used to analyze four samples (HP14-02, -05b, -09b, -10b) was shortened for the remaining four samples (HP14-03, -06, -07, -08) to improve accuracy and precision, primarily on ${ }^{207} \mathrm{~Pb}$ measurements. Parameters that varied by method are specified as either short (method) or long (method). 
Appendix C: LA-ICP-MS Quality Control and Validation

\begin{tabular}{|c|c|c|c|}
\hline \multirow{2}{*}{ Sample } & \multicolumn{3}{|c|}{ Secondary Standard } \\
\cline { 2 - 4 } & Peixe & Plešovice & Fish Canyon Tuff \\
\hline HP14-05, -09b & $561 \pm 12 \mathrm{Ma}(\mathrm{n}=23, \mathrm{MSWD}=0.79)$ & $348.6 \pm 8.5 \mathrm{Ma}(\mathrm{n}=21, \mathrm{MSWD}=1.8)$ & $\mathrm{N} / \mathrm{A}$ \\
HP14-02, -10b & $\mathrm{N} / \mathrm{A}$ & $342.6 \pm 7.9 \mathrm{Ma}(\mathrm{n}=27, \mathrm{MSWD}=1.3)$ & $28.7 \pm 1.3 \mathrm{Ma}(\mathrm{n}=25, \mathrm{MSWD}=1.8)$ \\
HP14-03, -08 & $\mathrm{N} / \mathrm{A}$ & $\mathrm{N} / \mathrm{A}$ & $28.6 \pm 1.7 \mathrm{Ma}(\mathrm{n}=25, \mathrm{MSWD}=2.1)$ \\
HP14-06 & $\mathrm{N} / \mathrm{A}$ & $\mathrm{N} / \mathrm{A}$ & $28.62 \pm 0.91 \mathrm{Ma}(\mathrm{n}=24, \mathrm{MSWD}=0.51)$ \\
HP14-07 & $\mathrm{N} / \mathrm{A}$ & $\mathrm{N} / \mathrm{A}$ & $28.5 \pm 1.0 \mathrm{Ma}(\mathrm{n}=17, \mathrm{MSWD}=1.6)$ \\
\hline Accepted Age & $\mathbf{5 6 4} \pm \mathbf{4} \mathbf{M a}^{\mathbf{a}}$ & $\mathbf{3 3 7 . 2} \pm \mathbf{0 . 1 3} \mathbf{M a}^{\mathbf{b}}$ & $\mathbf{c a .} \mathbf{2 8 . 6 4 2} \pm \mathbf{0 . 0 2 5} \mathbf{M a}$ to \\
\hline
\end{tabular}

Weighted average ${ }^{206} \mathrm{~Pb} /{ }^{238} \mathrm{U}$ ages $\pm 2 \mathrm{~s}:{ }^{\mathrm{a}} \mathrm{G}$. Gehrels, unpublished data; ${ }^{\mathrm{b}}$ Horstwood et al., 2016; ' Wotzlaw et al., 2013. 


\section{Appendix D: LA-ICP-MS U-Pb Zircon Data}

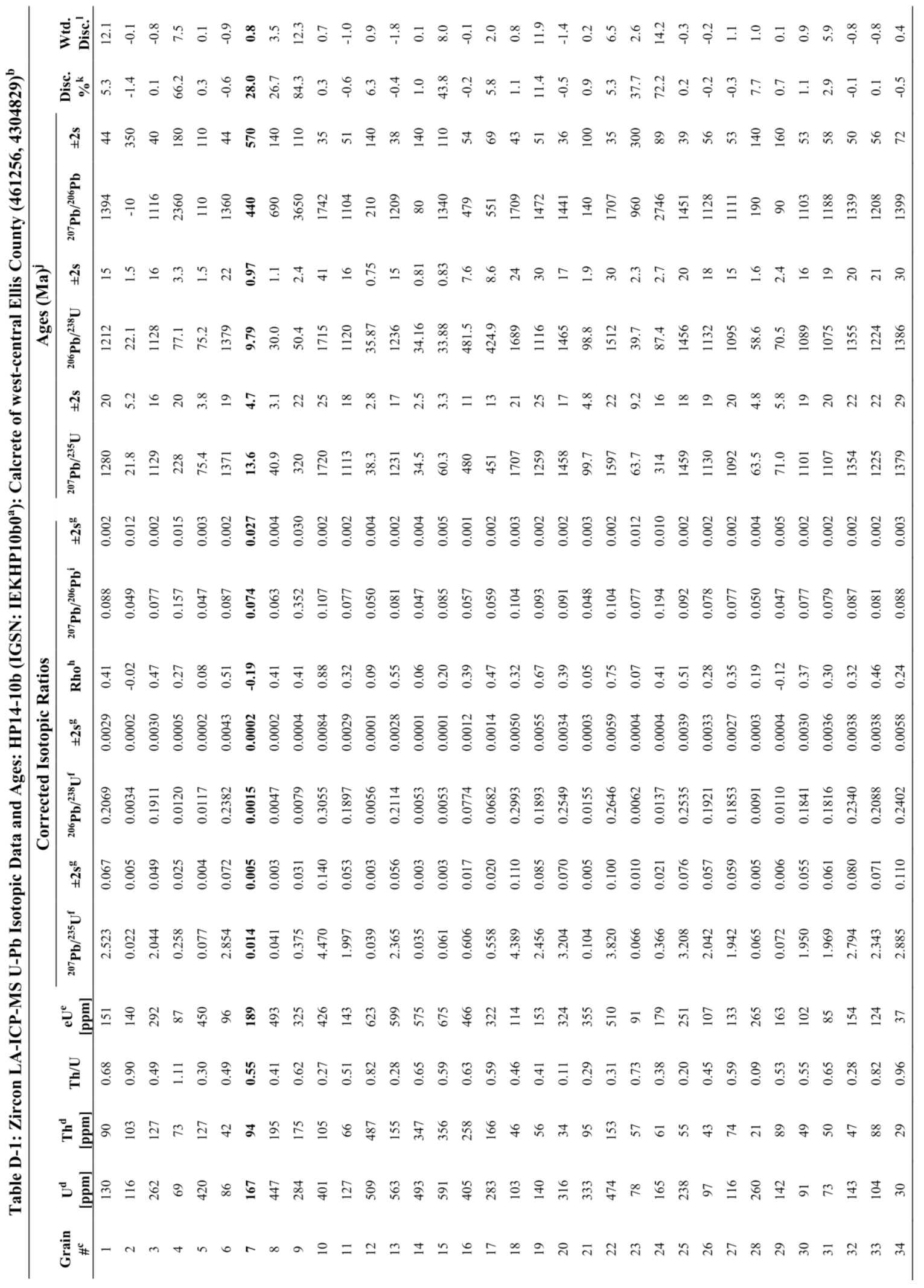




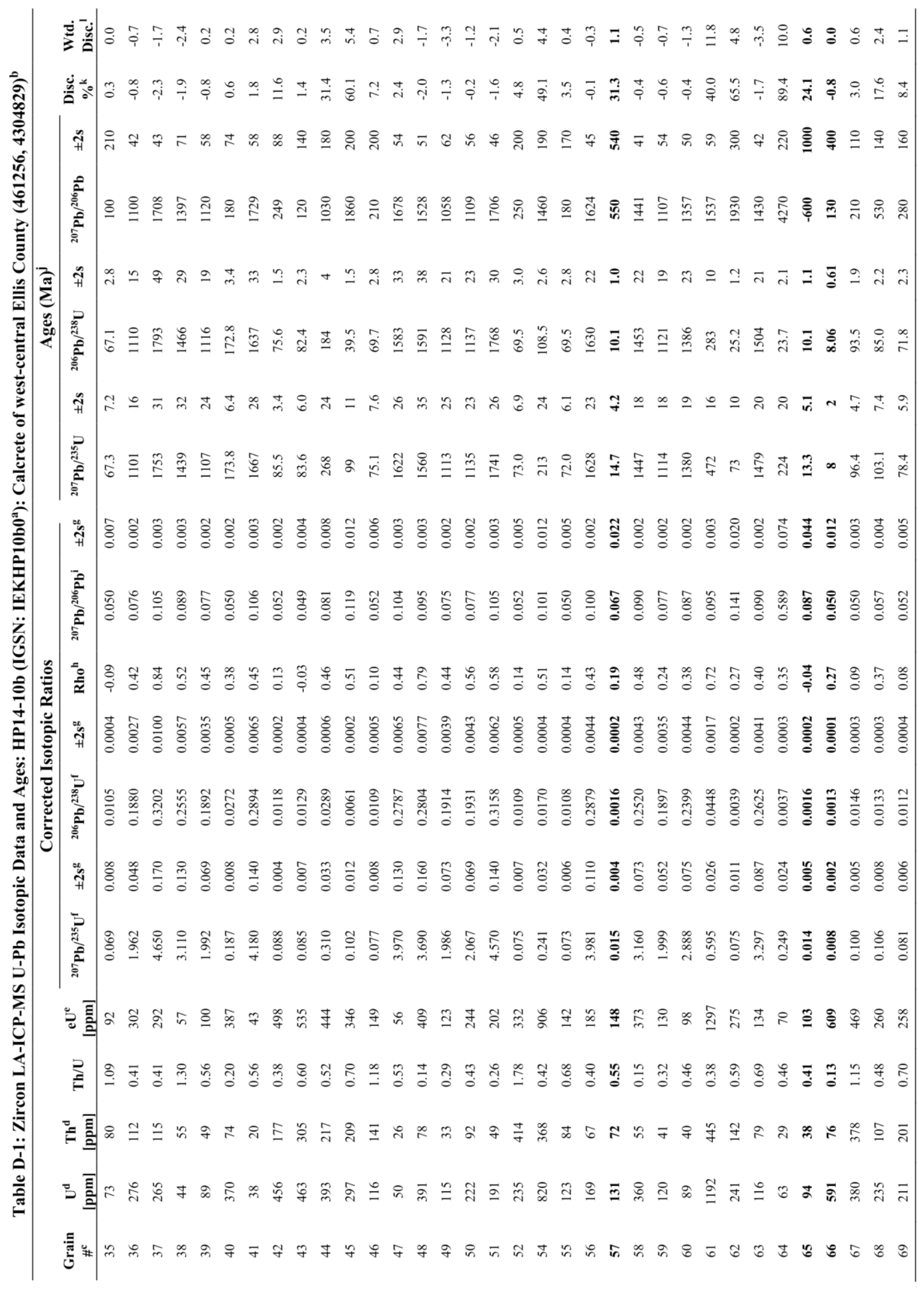




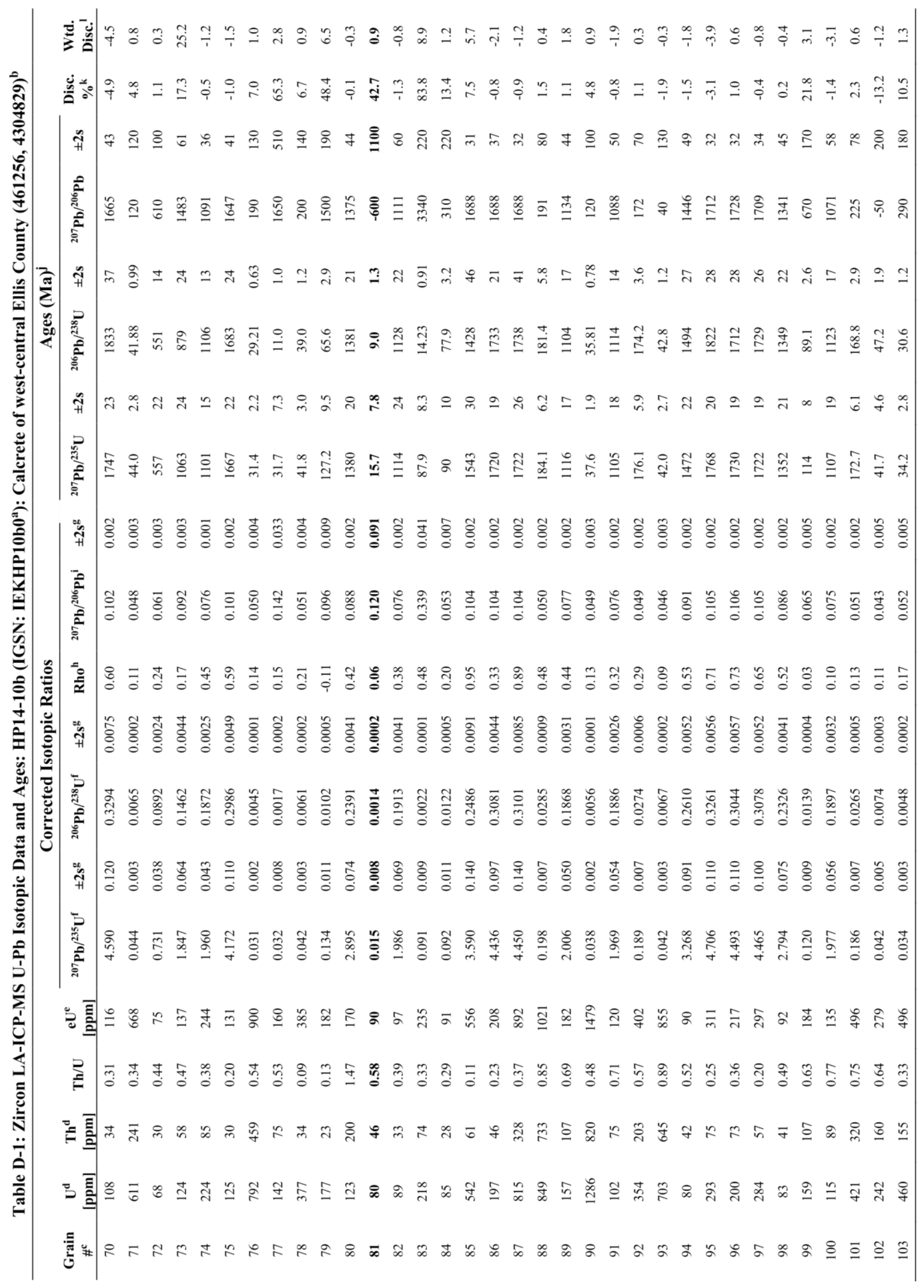




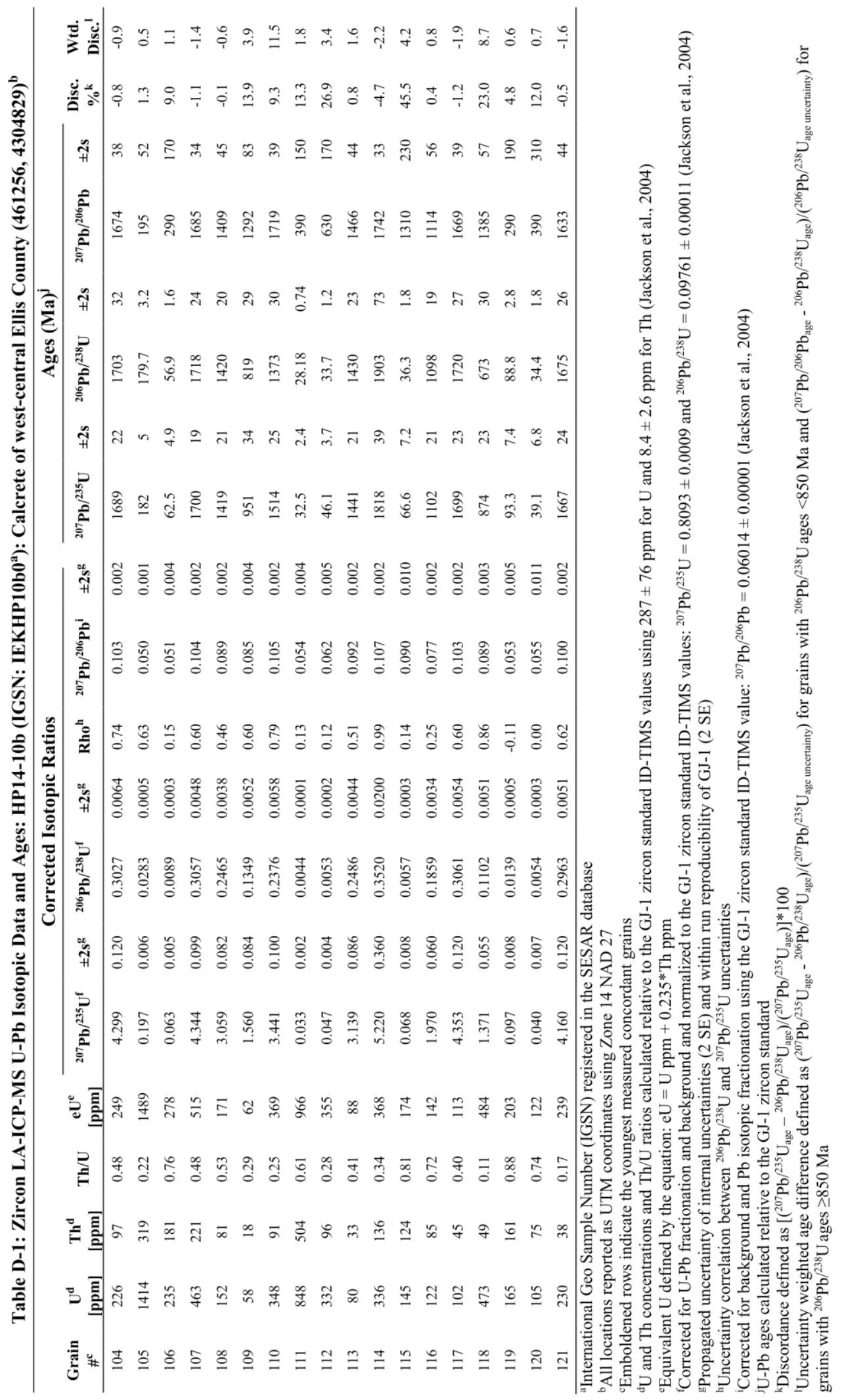




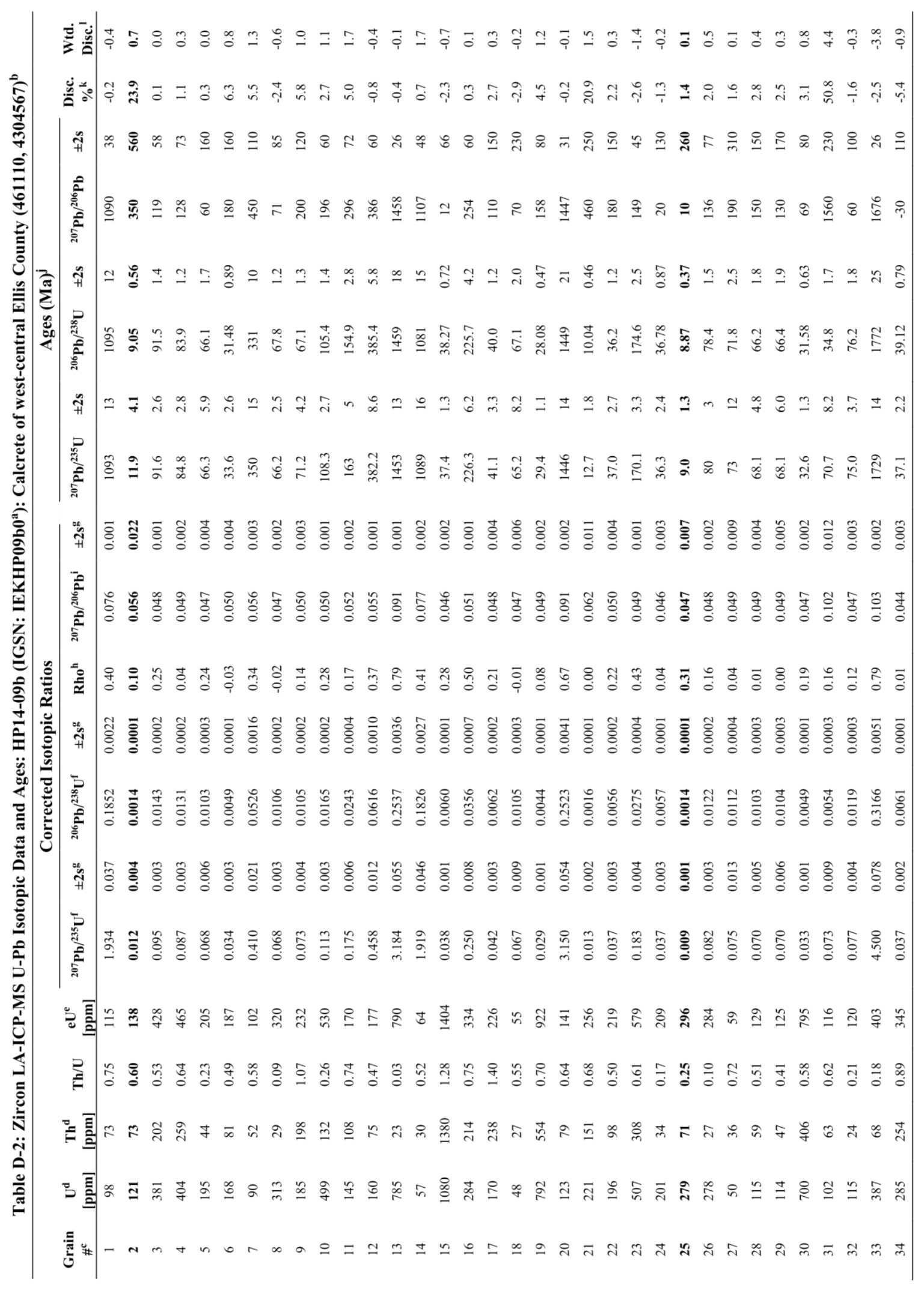




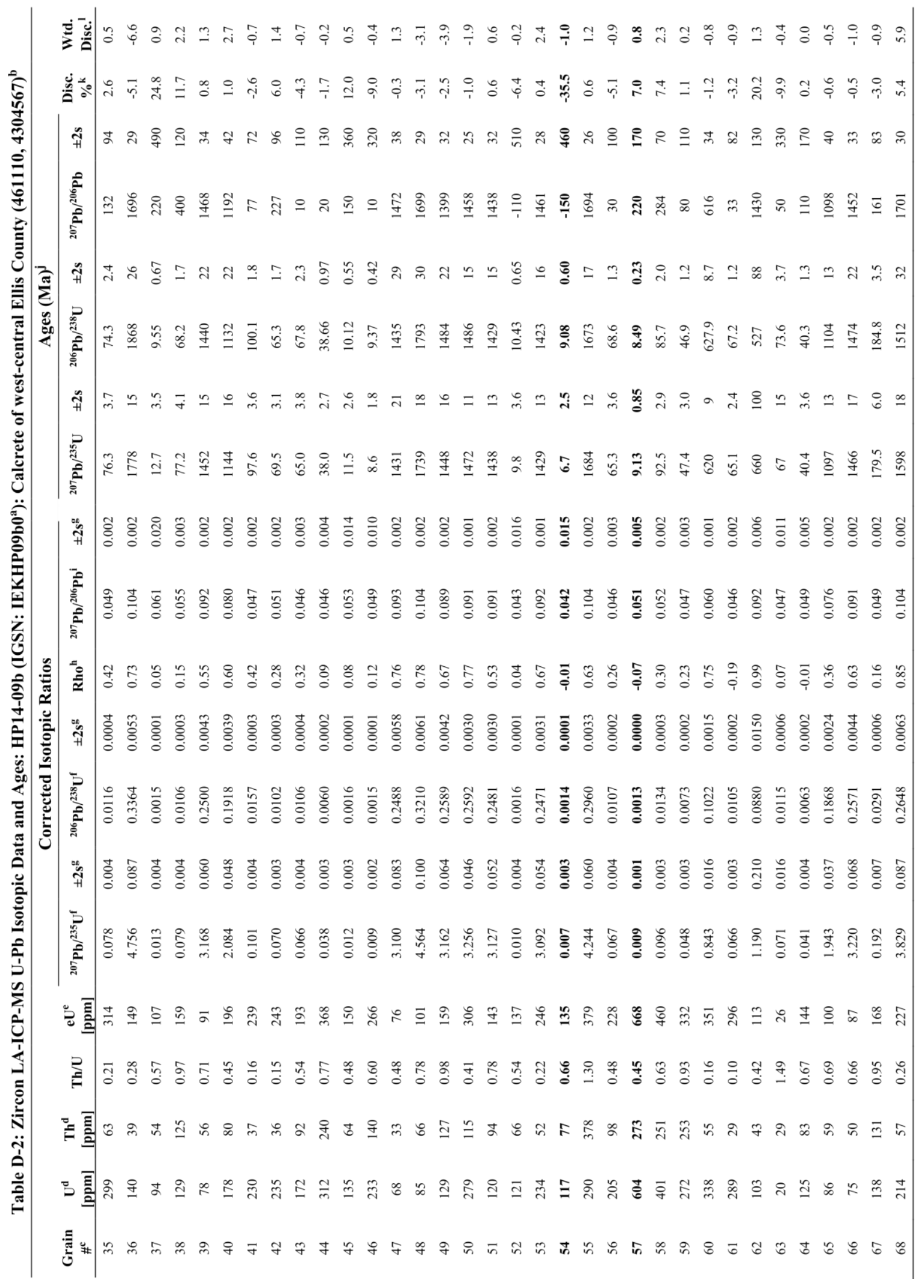




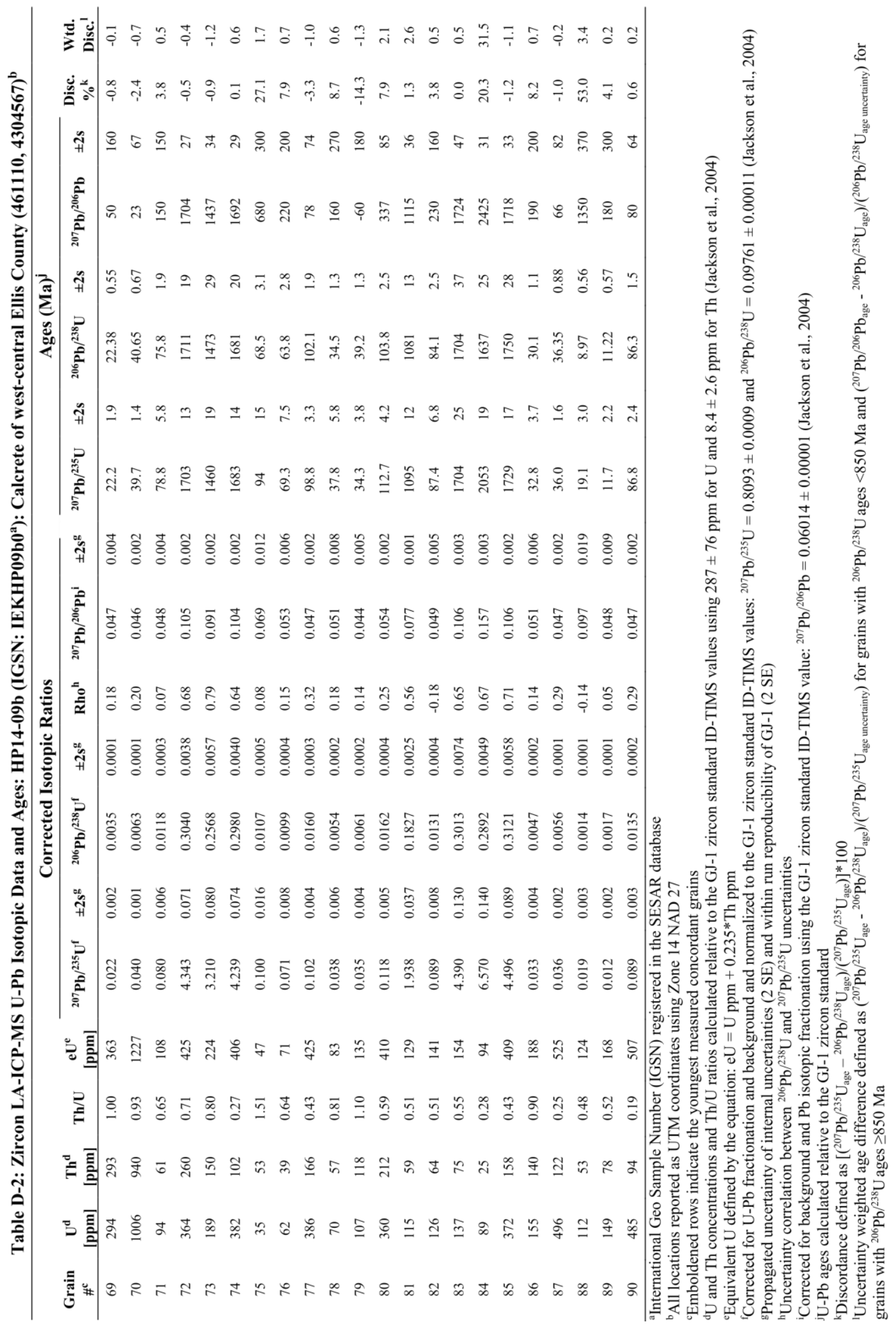




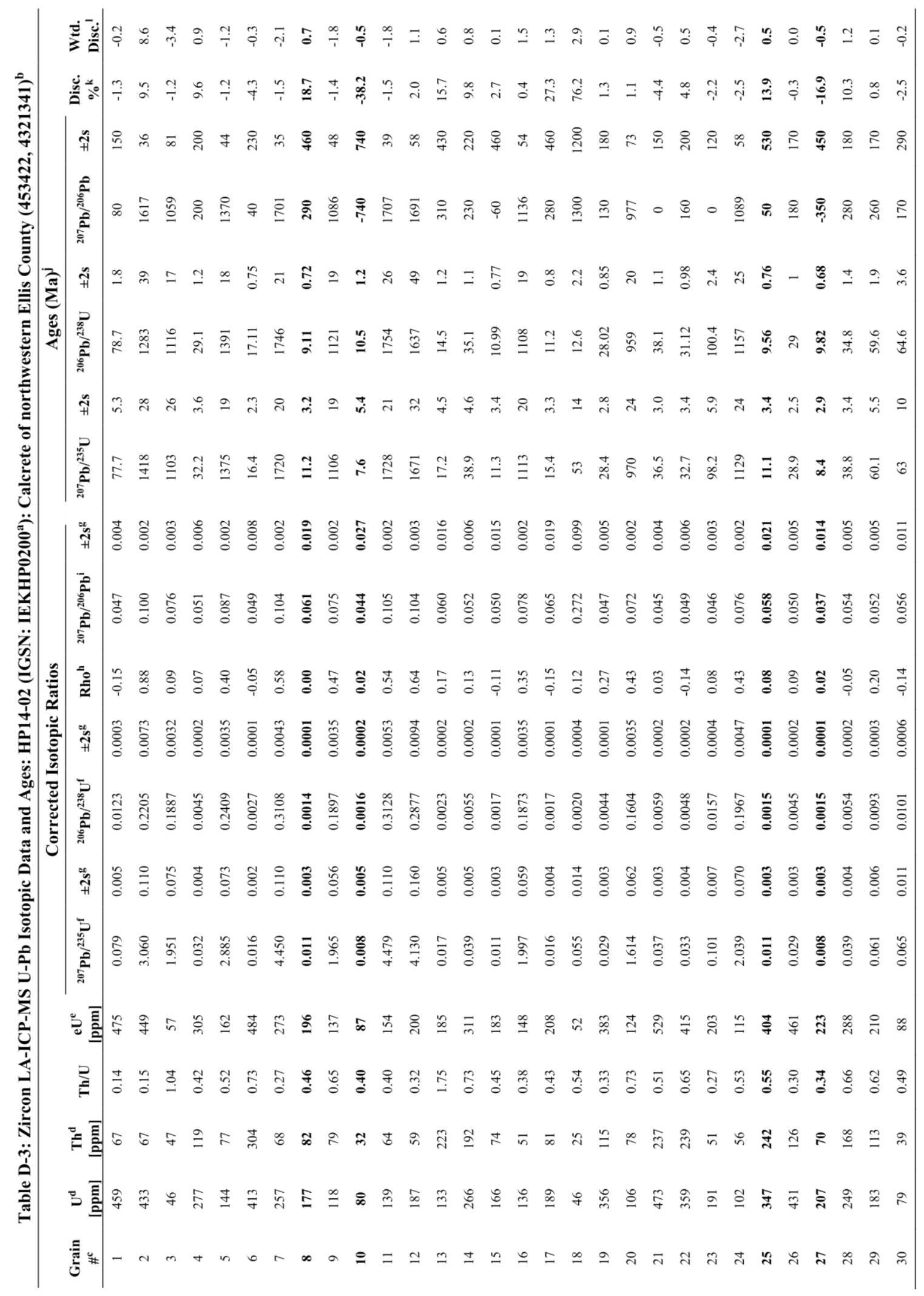




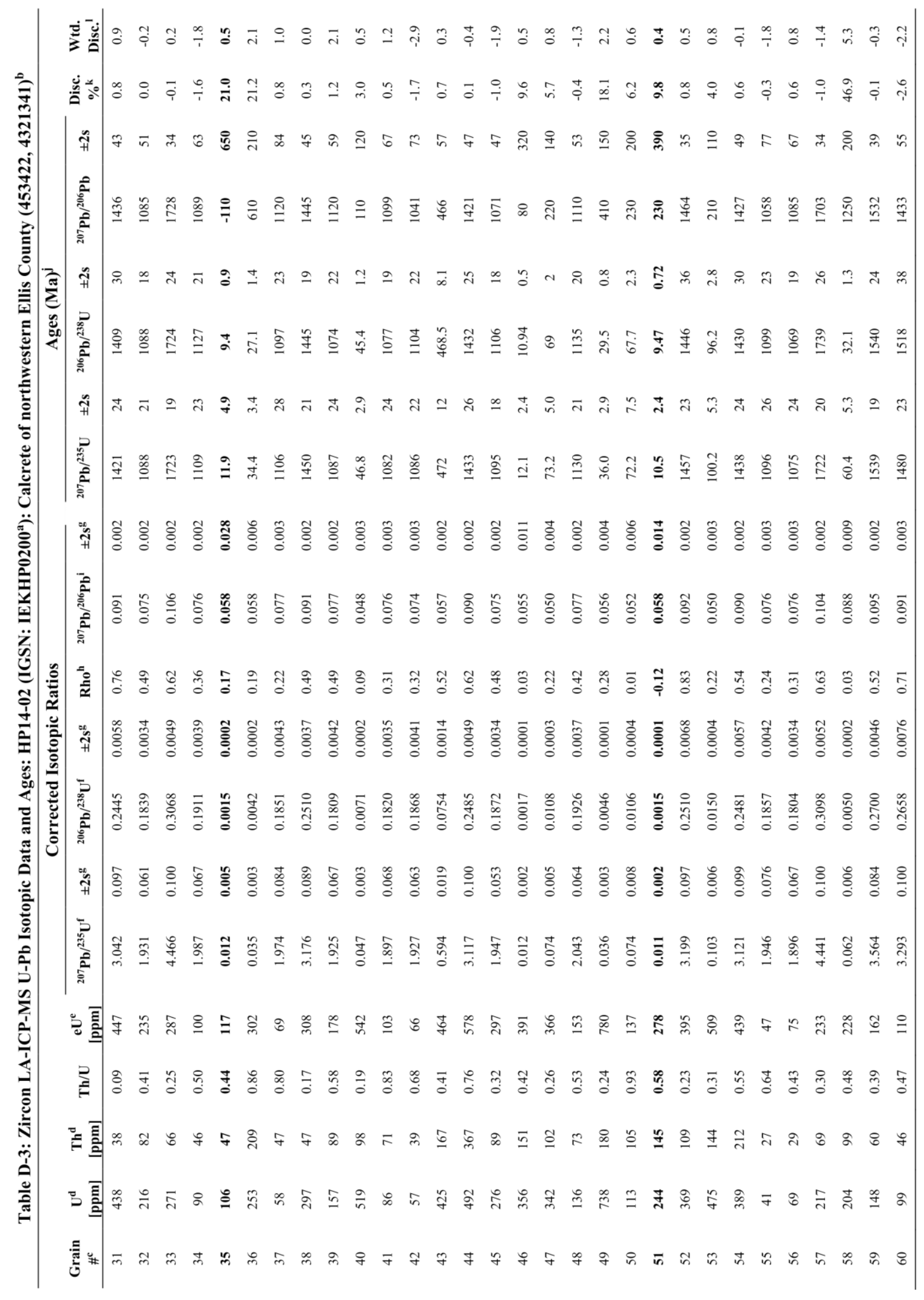




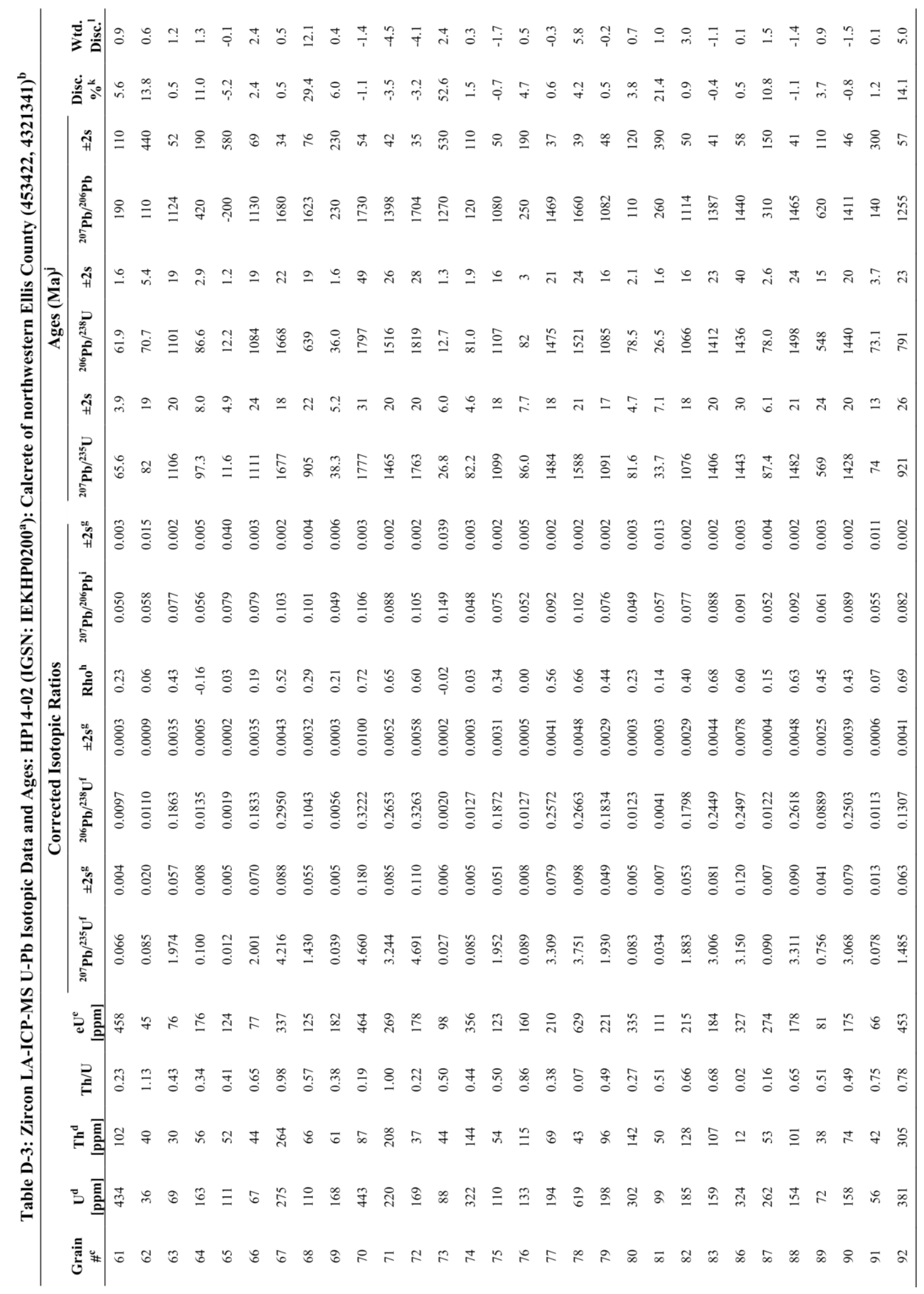




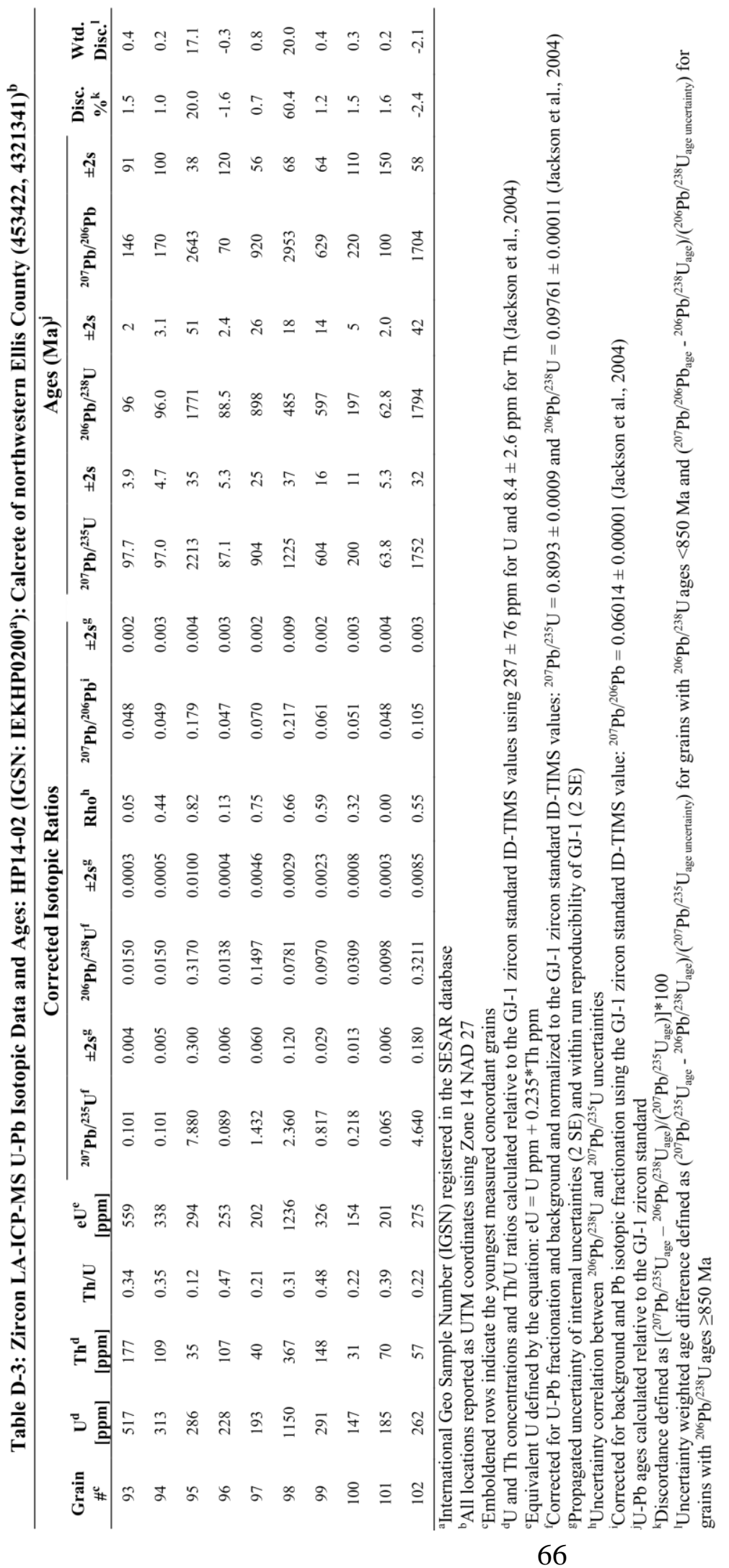




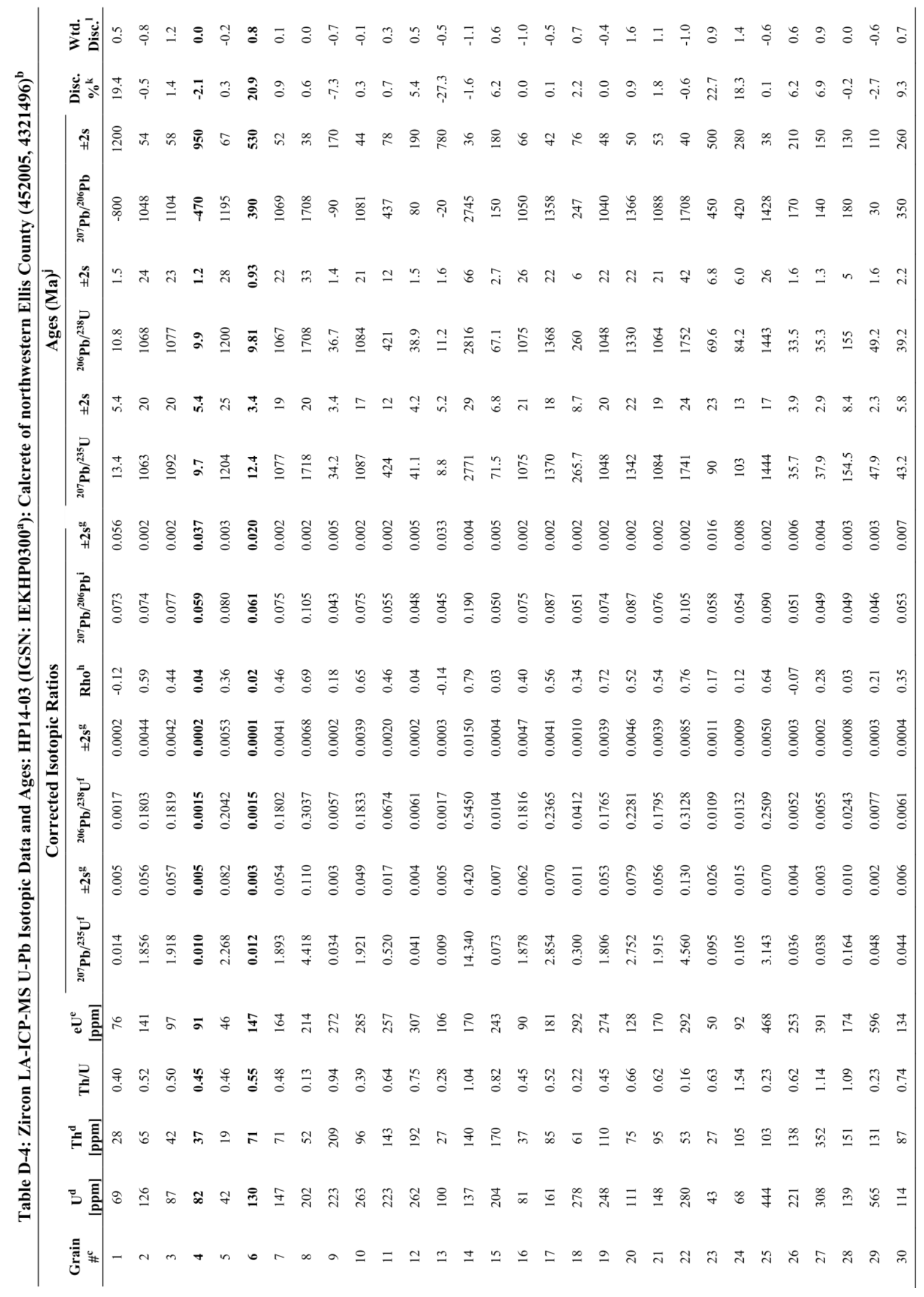




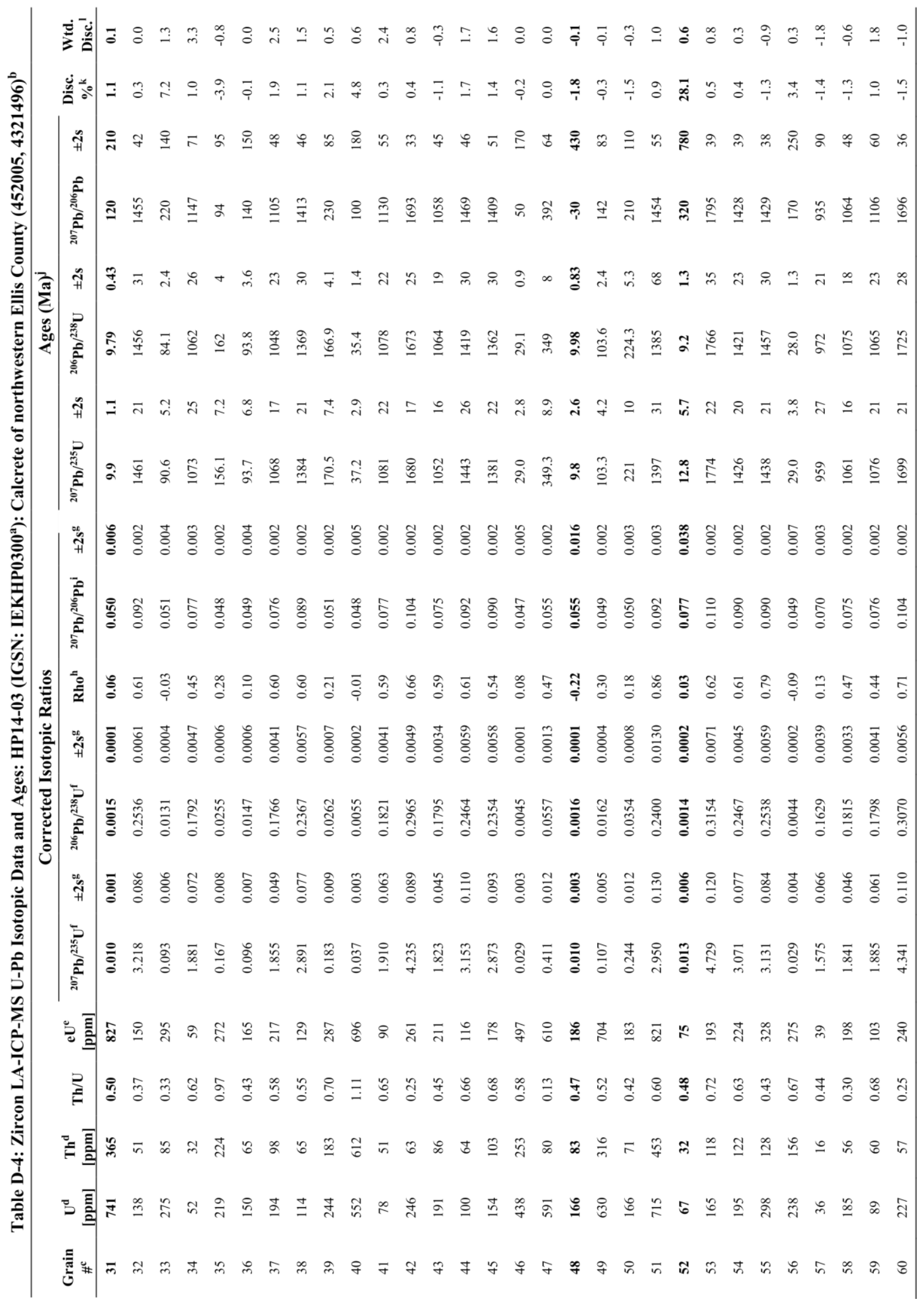




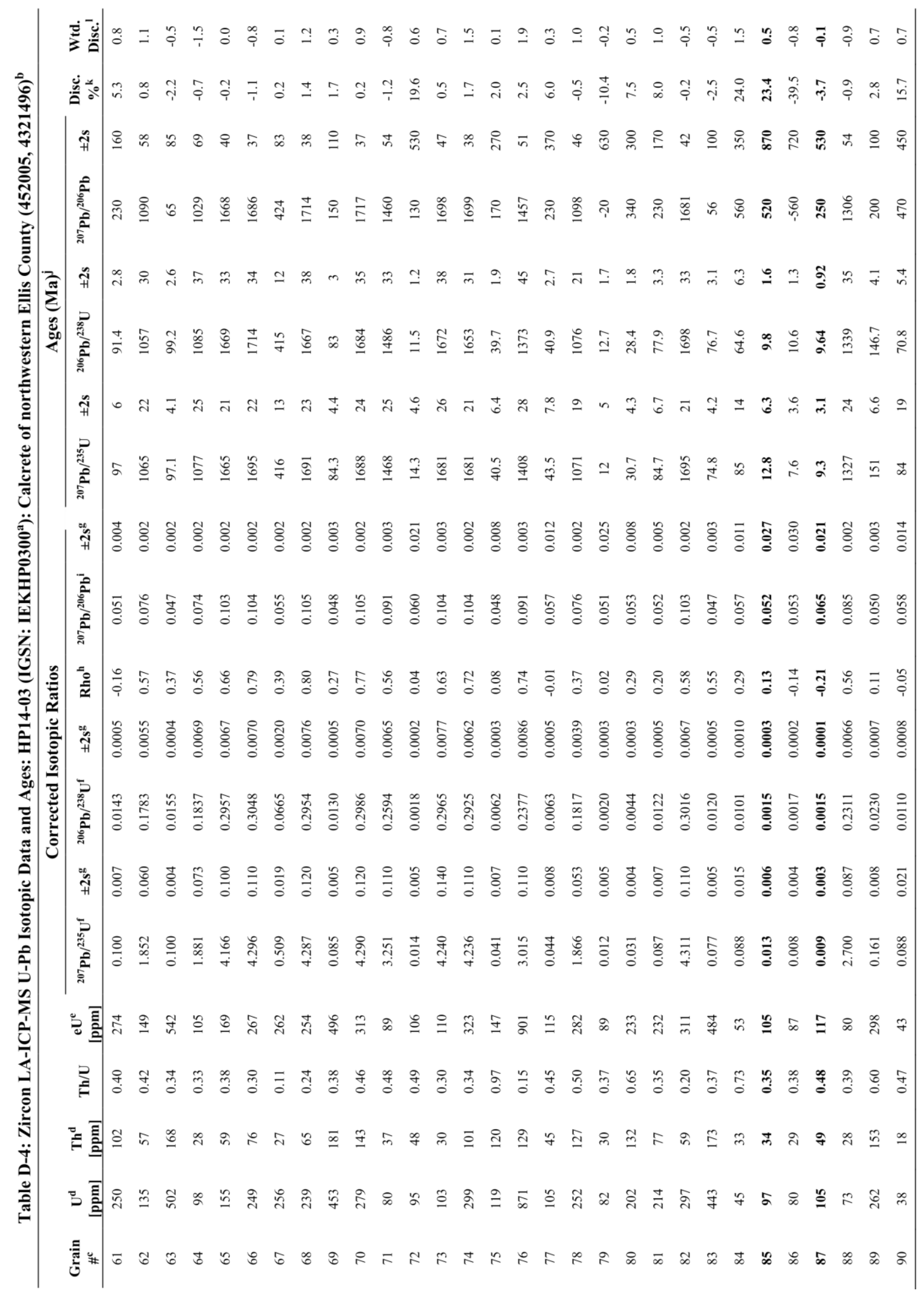




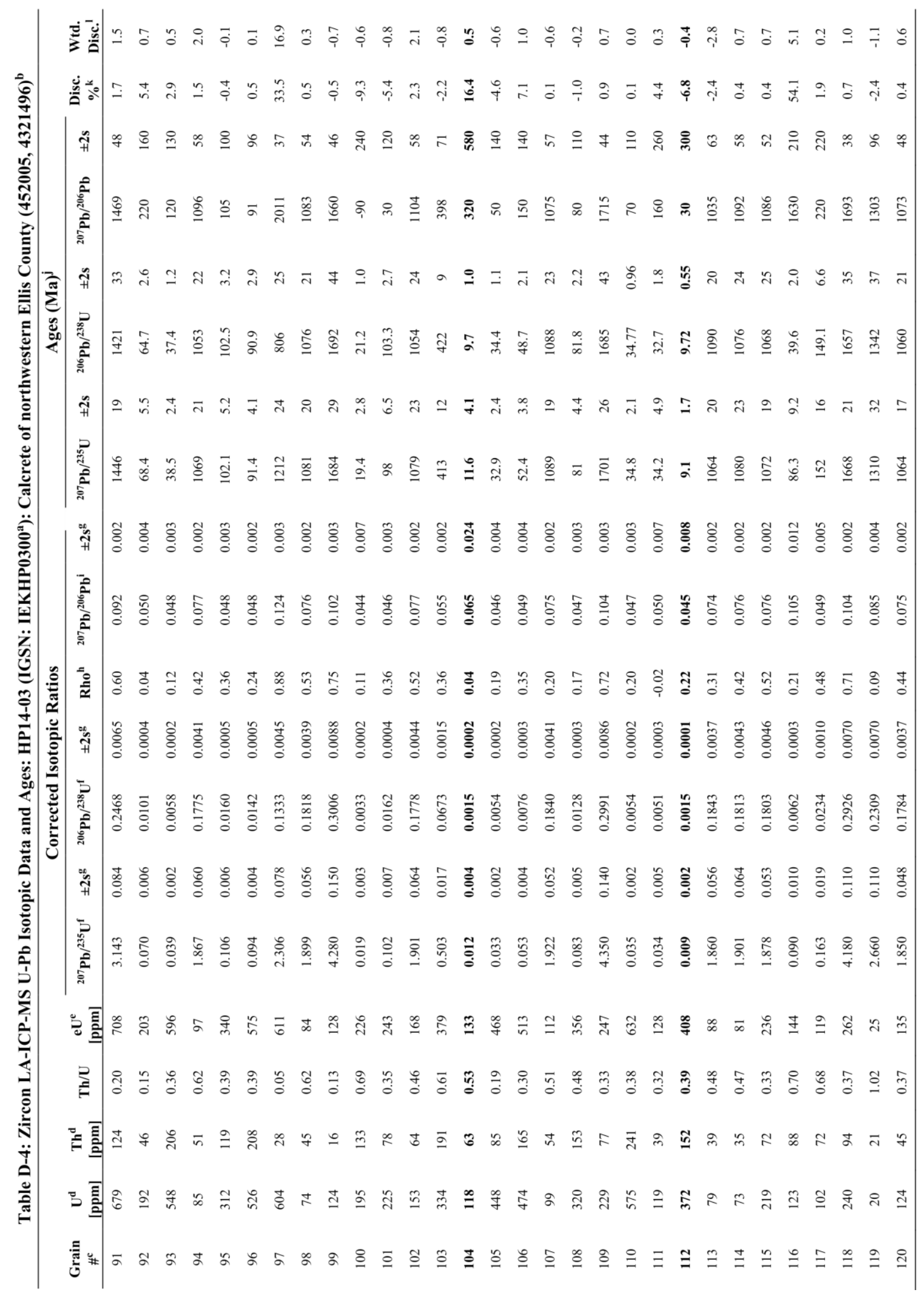




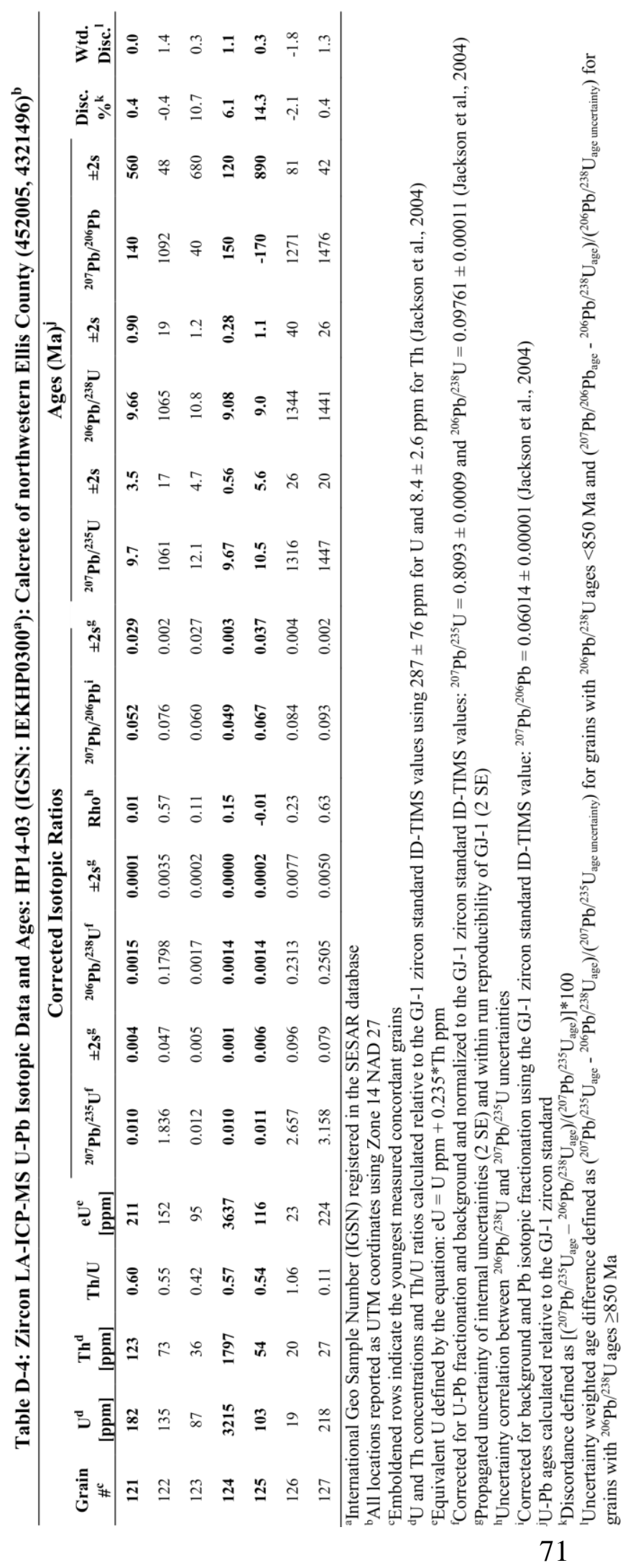




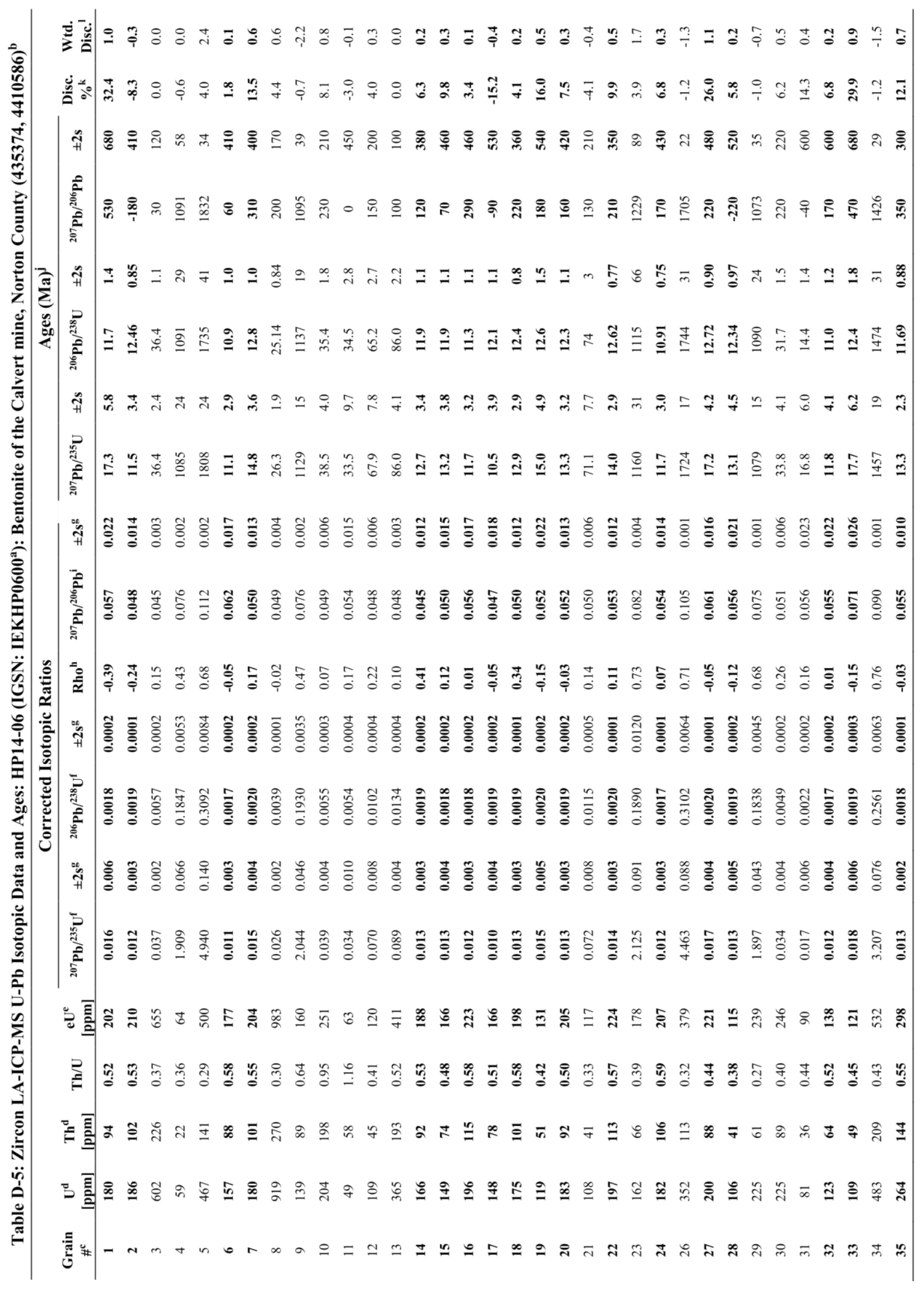




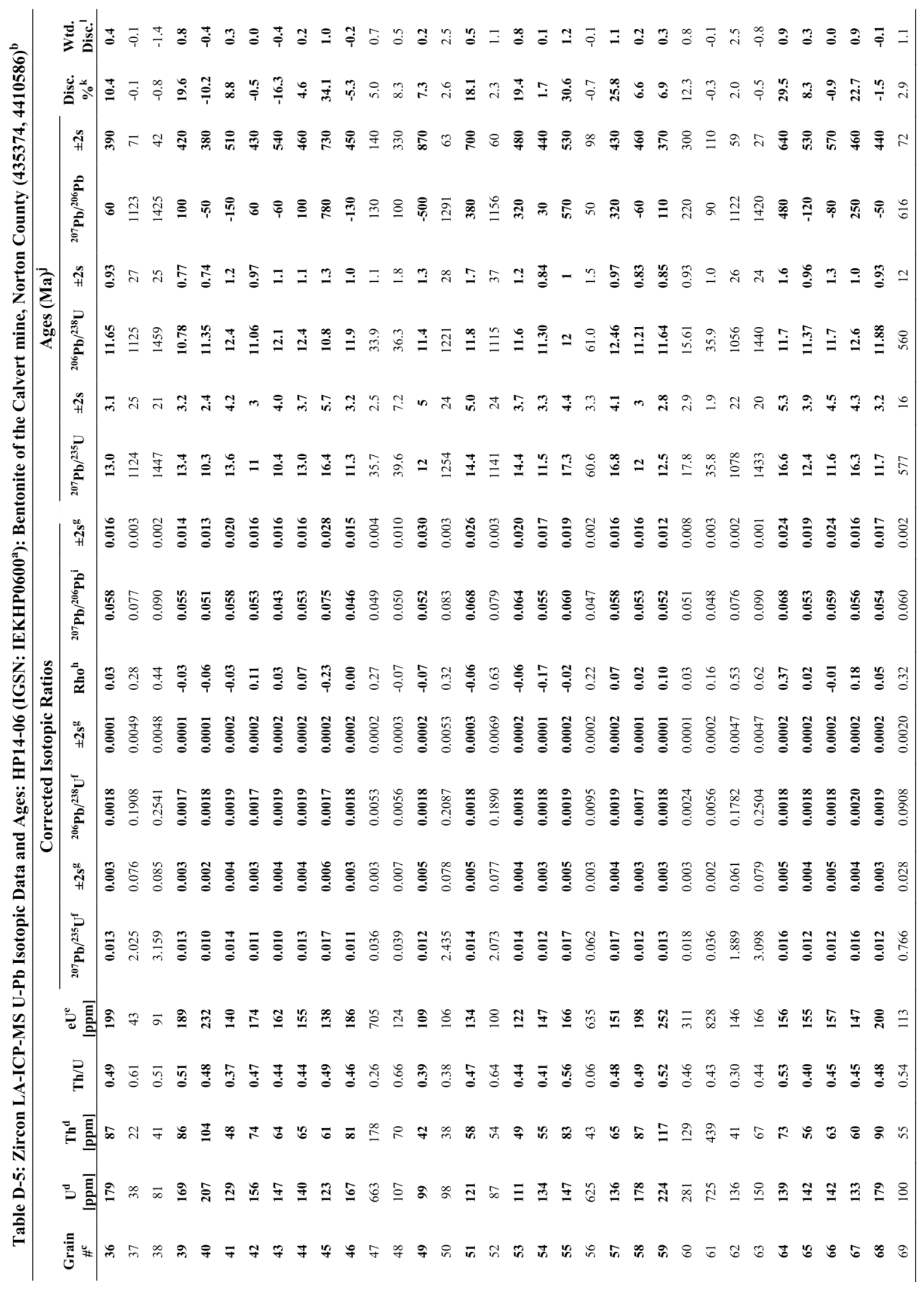




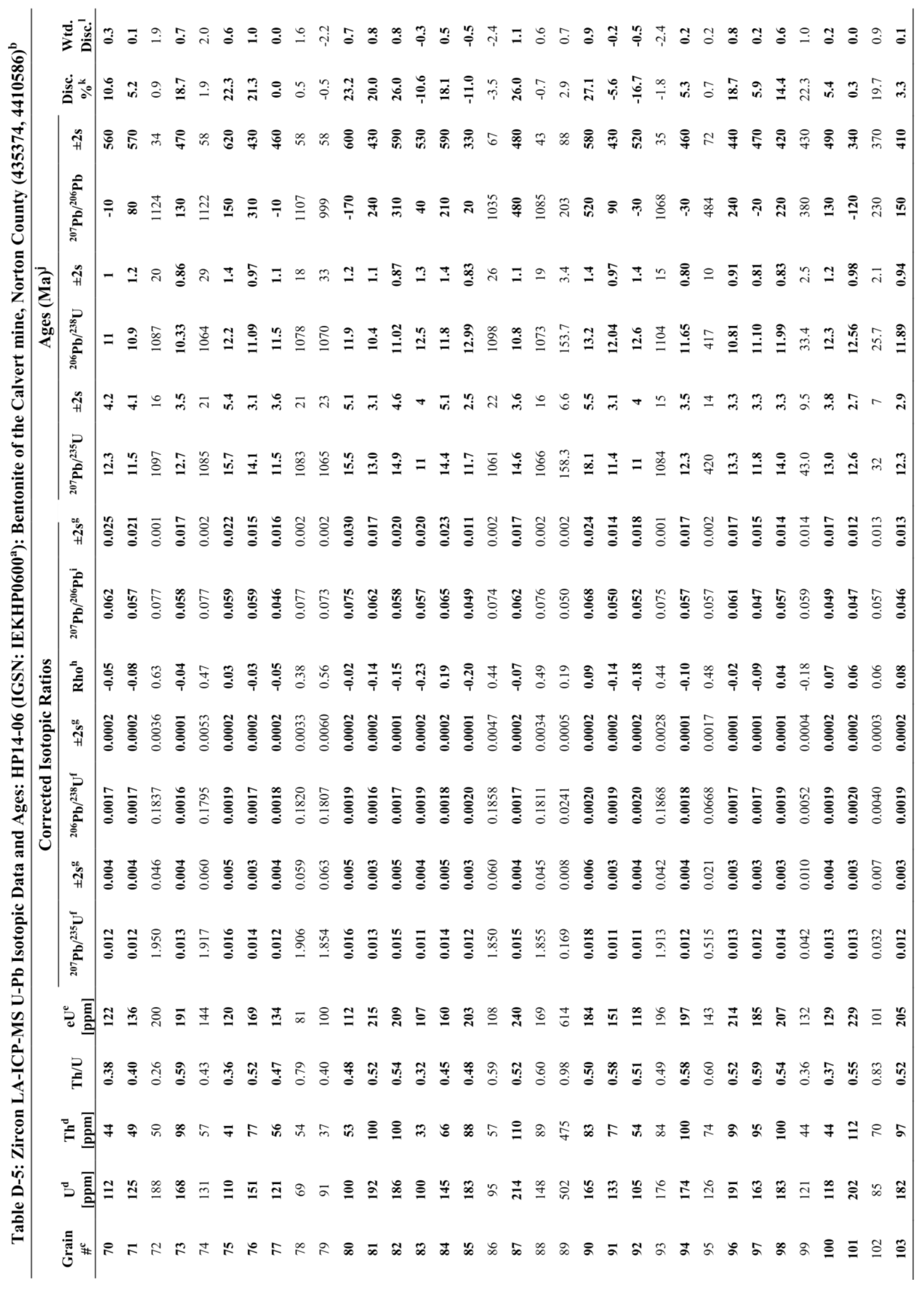




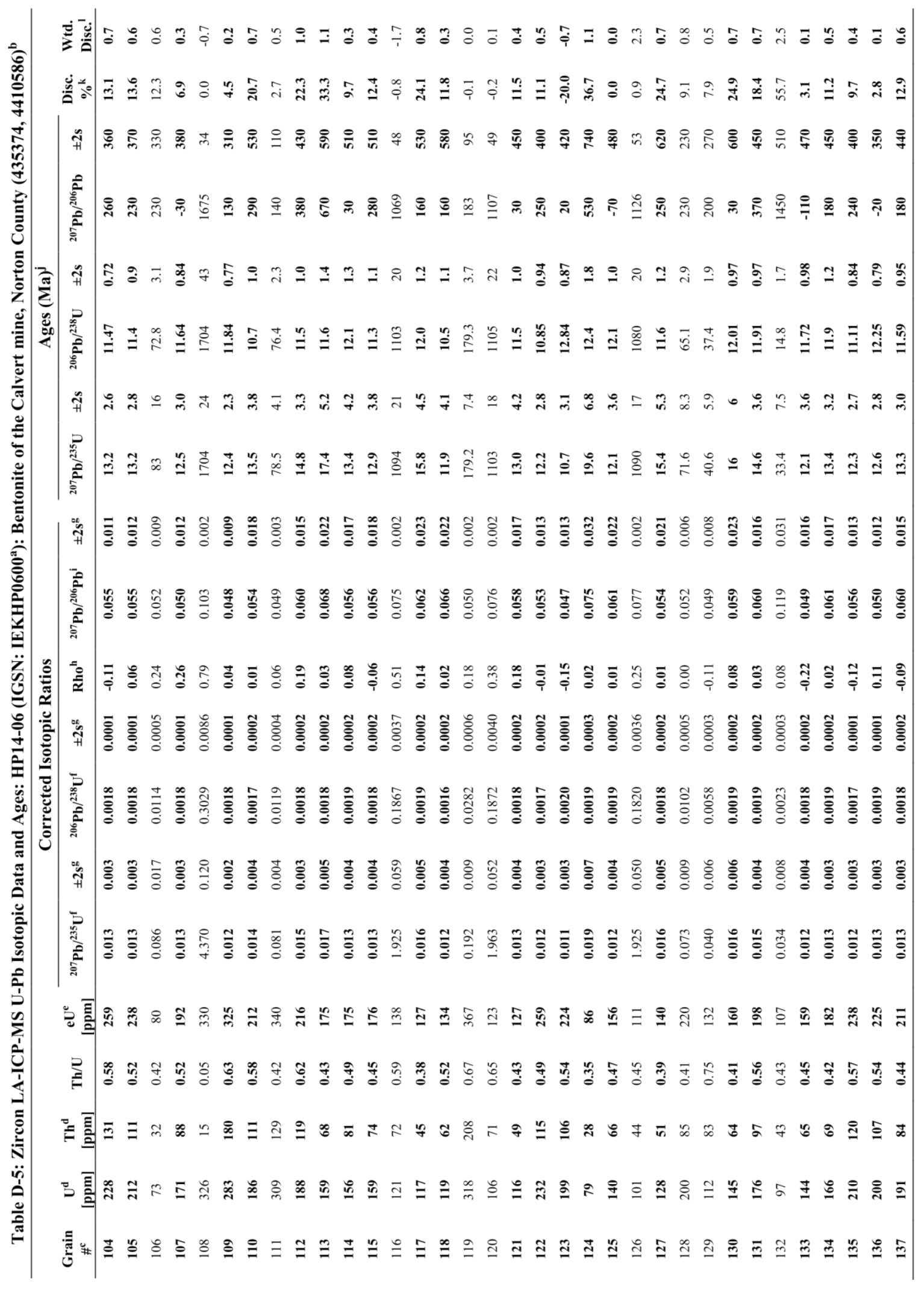




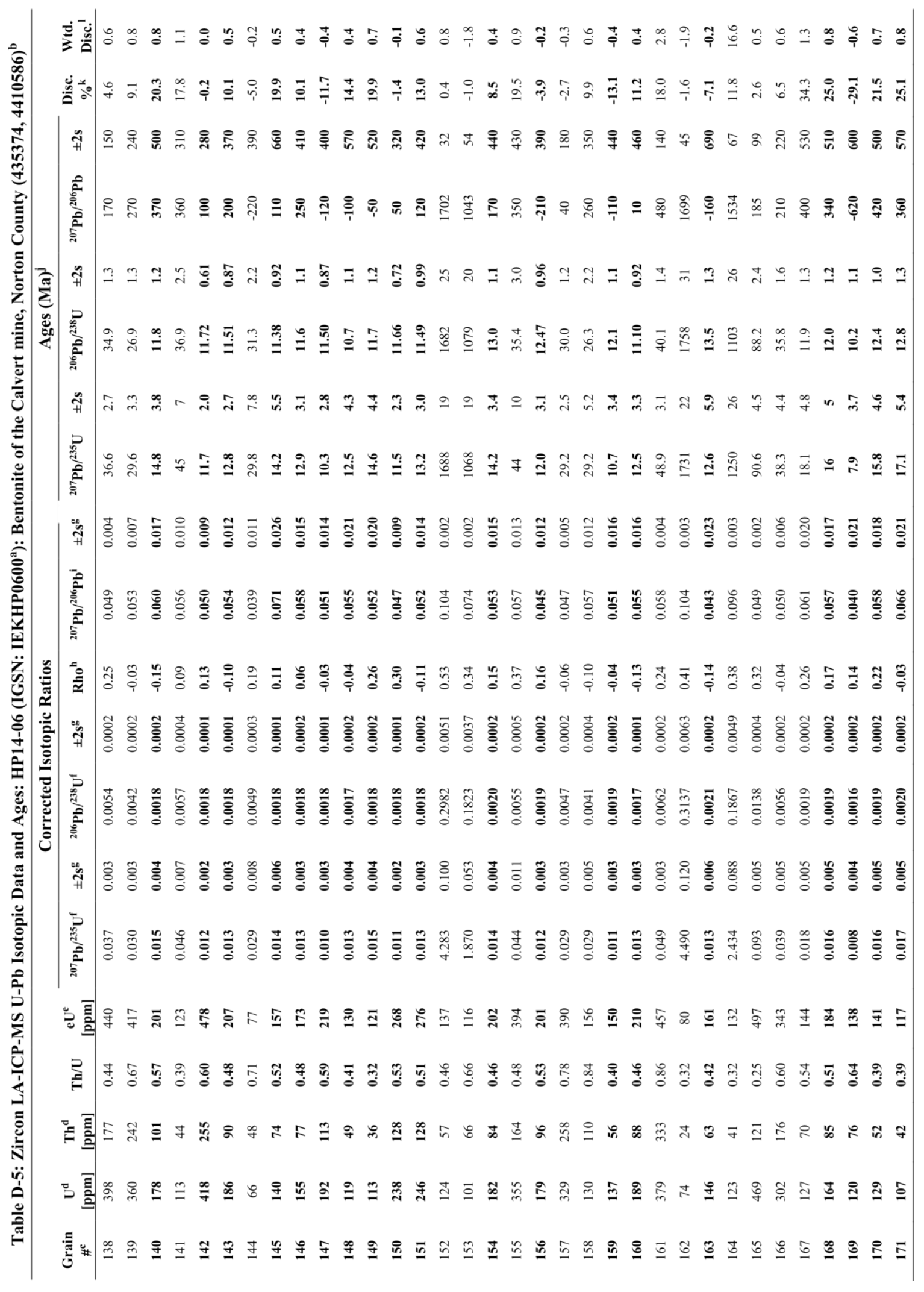




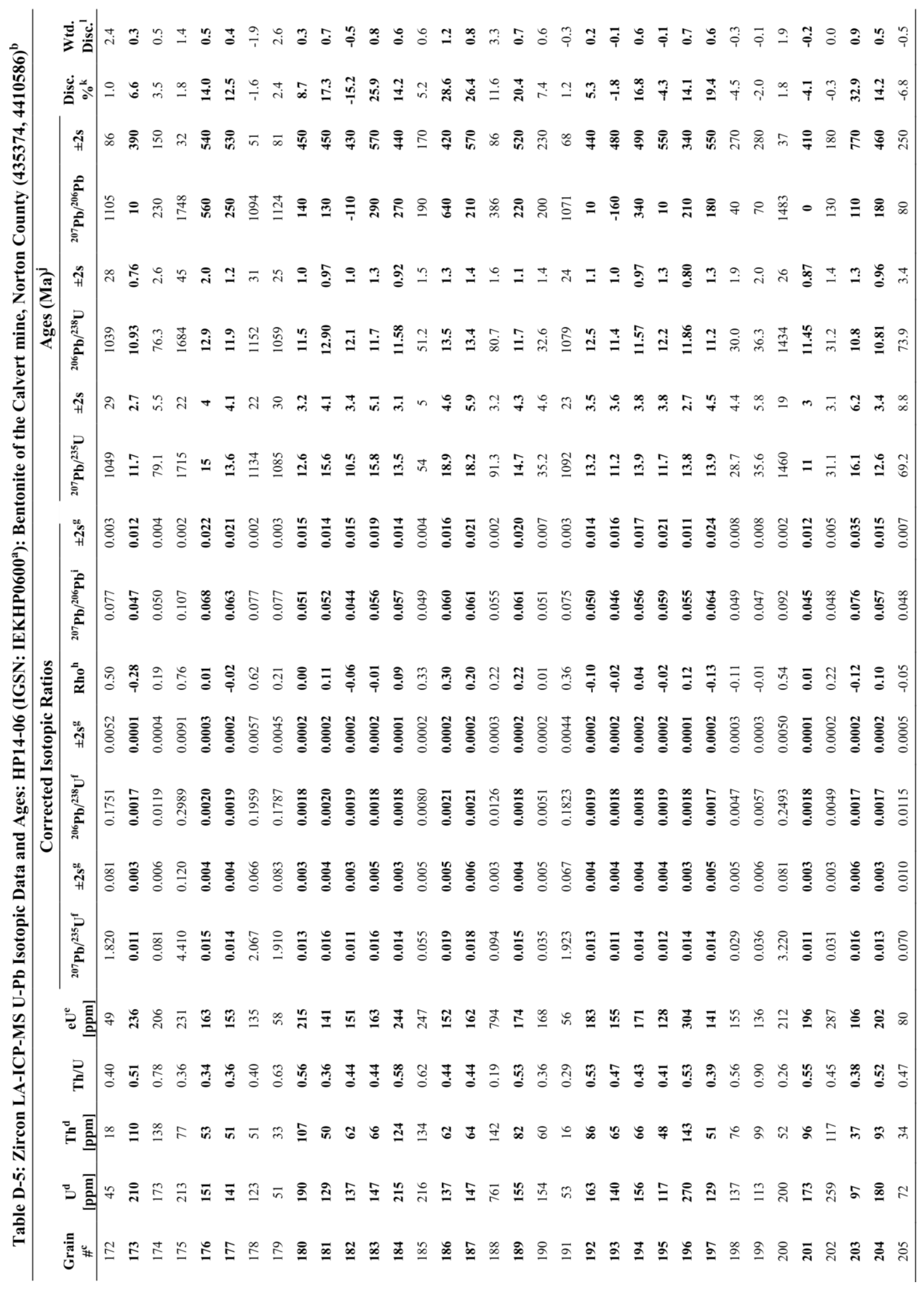




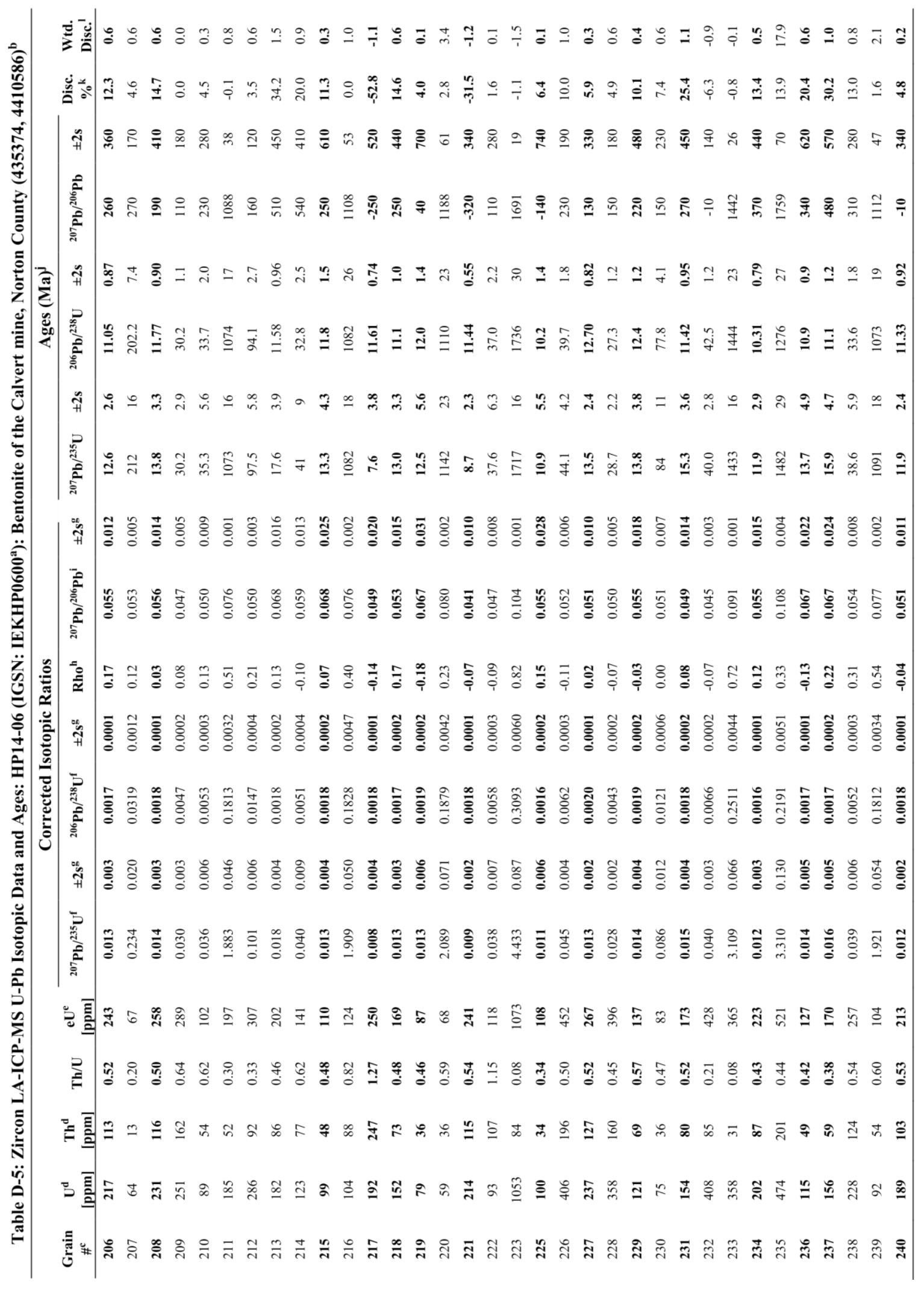




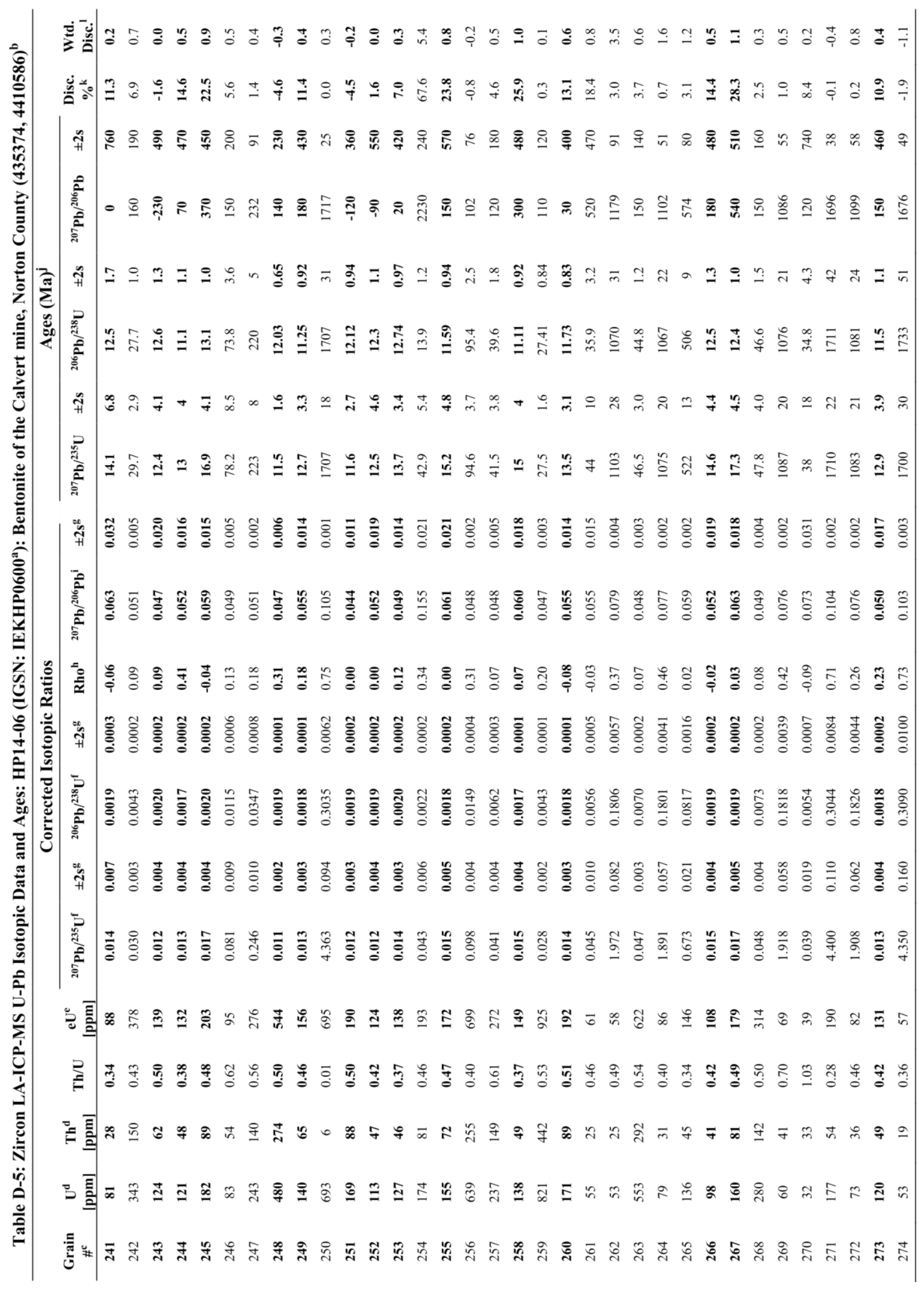




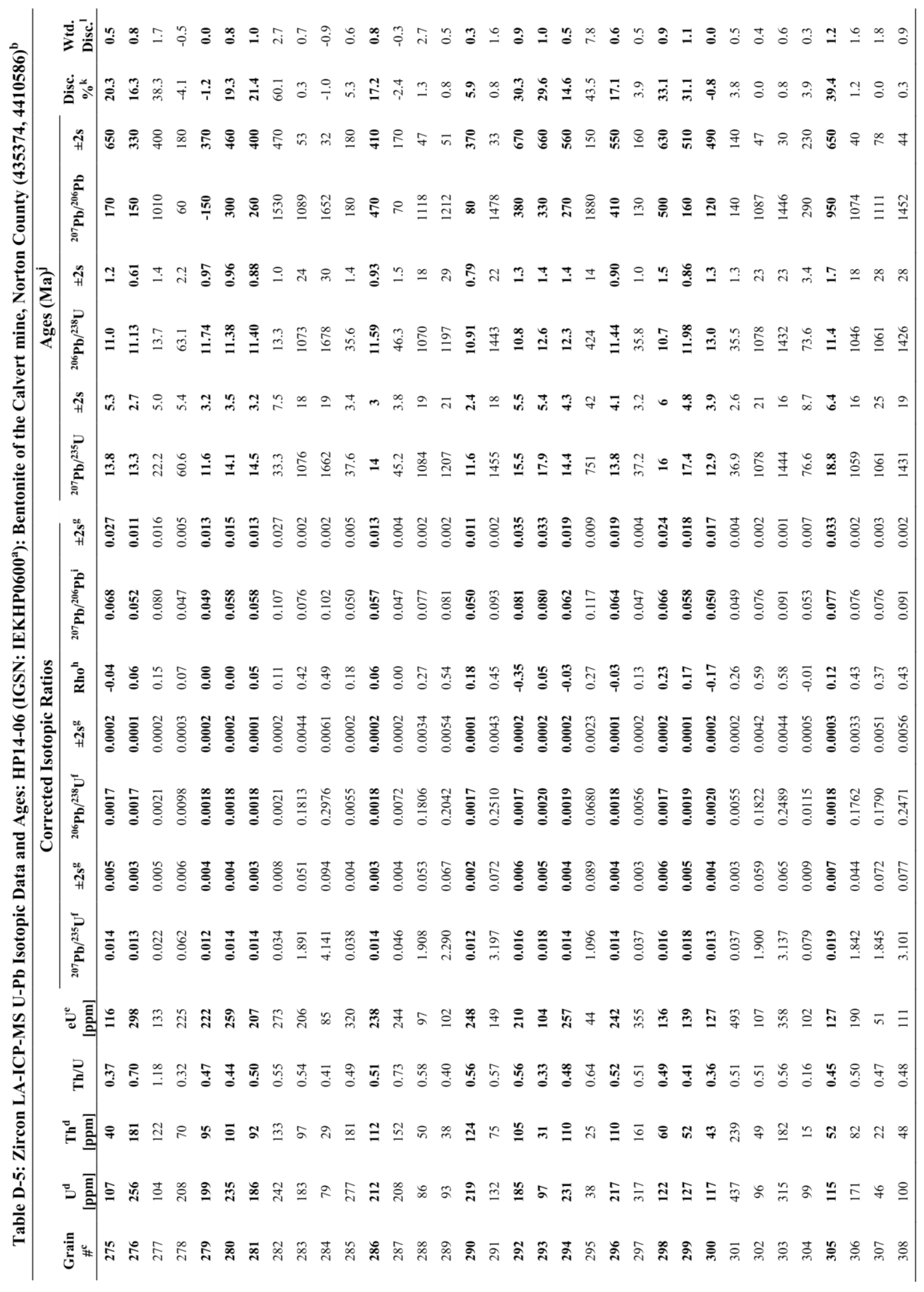




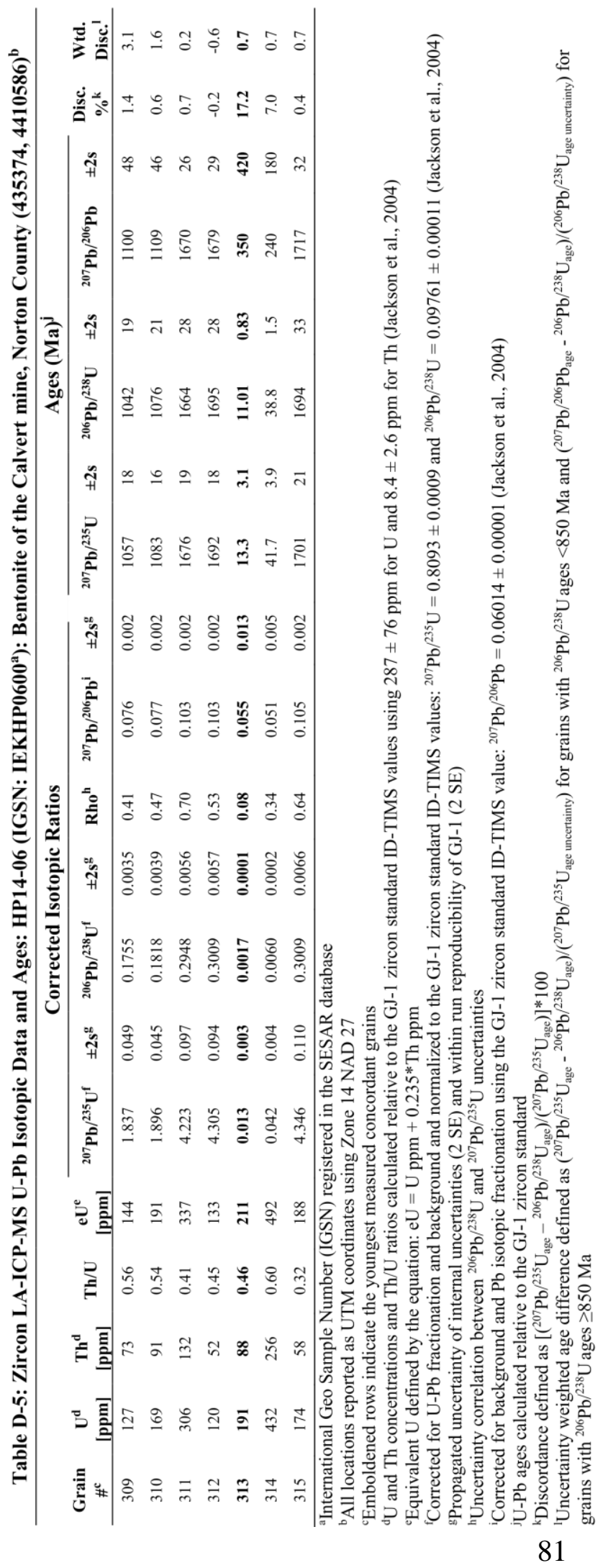




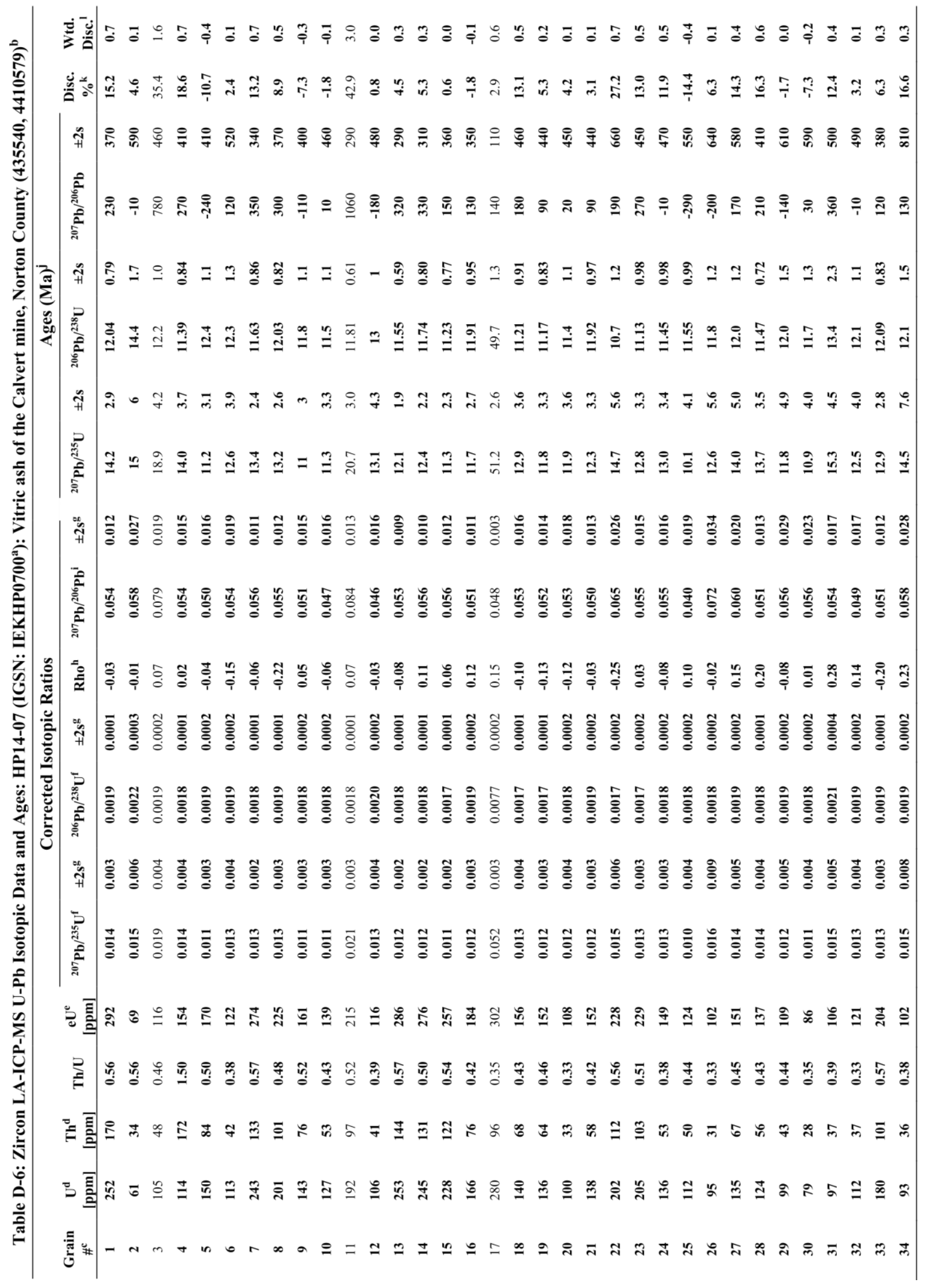




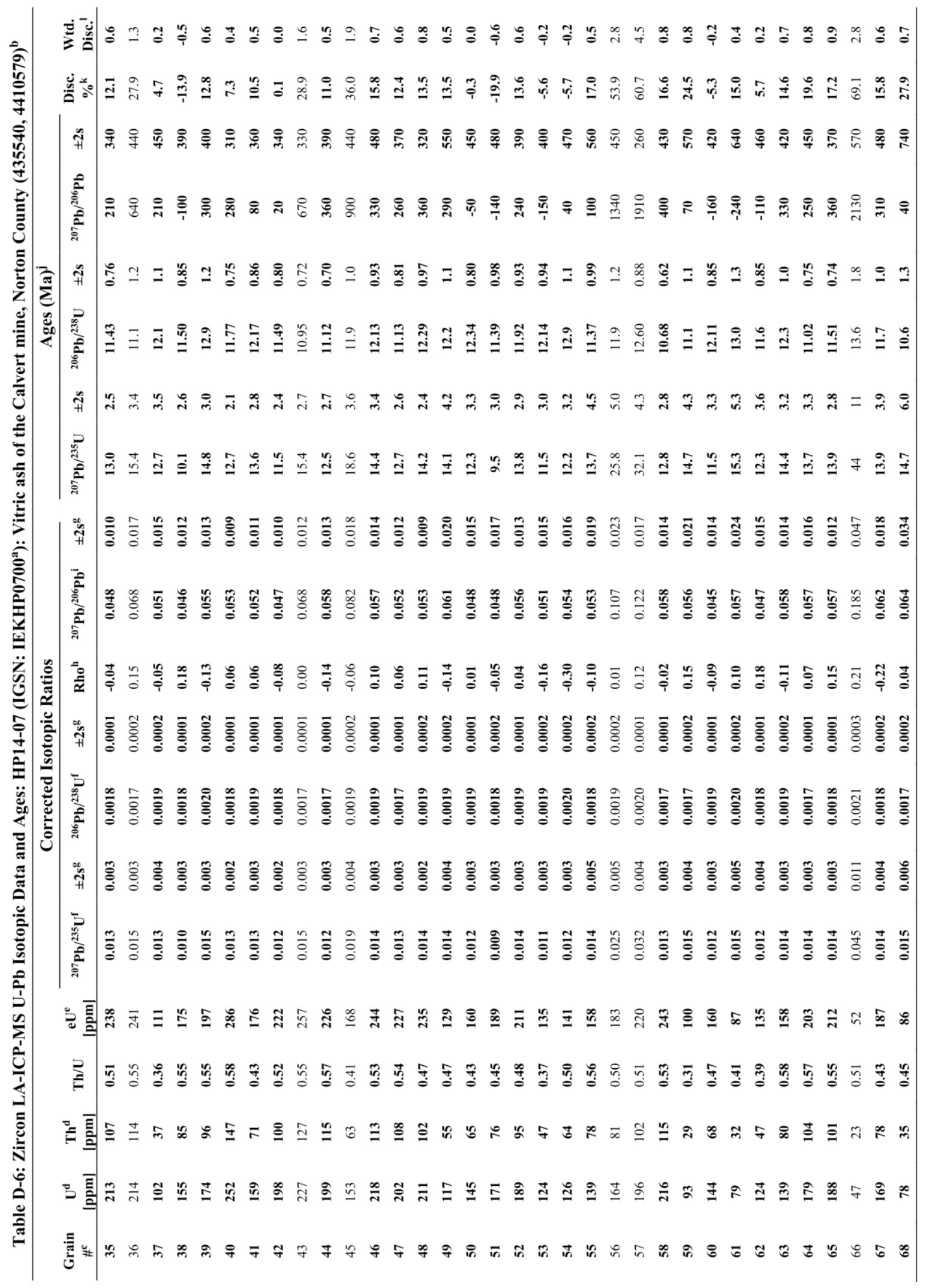




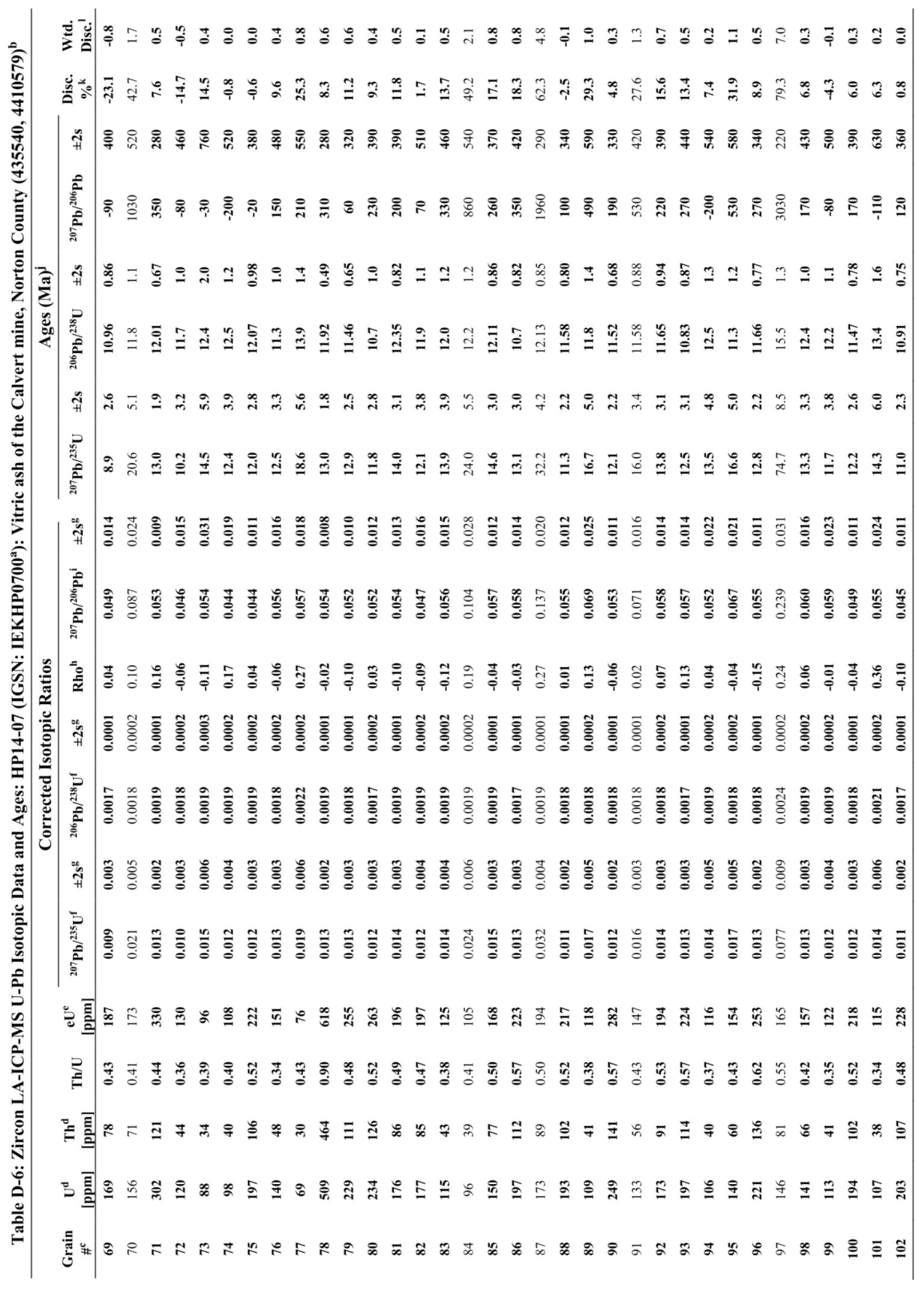




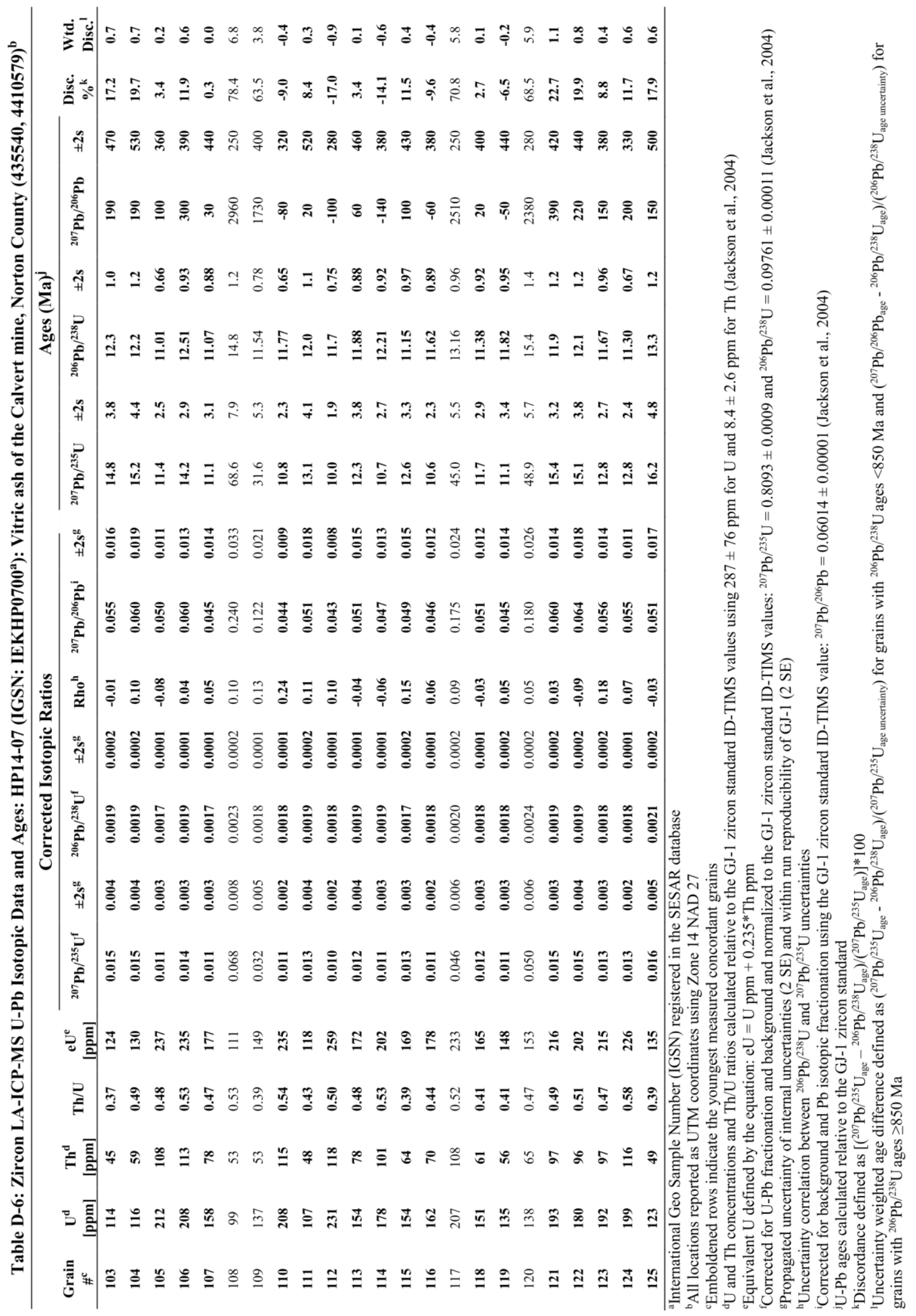




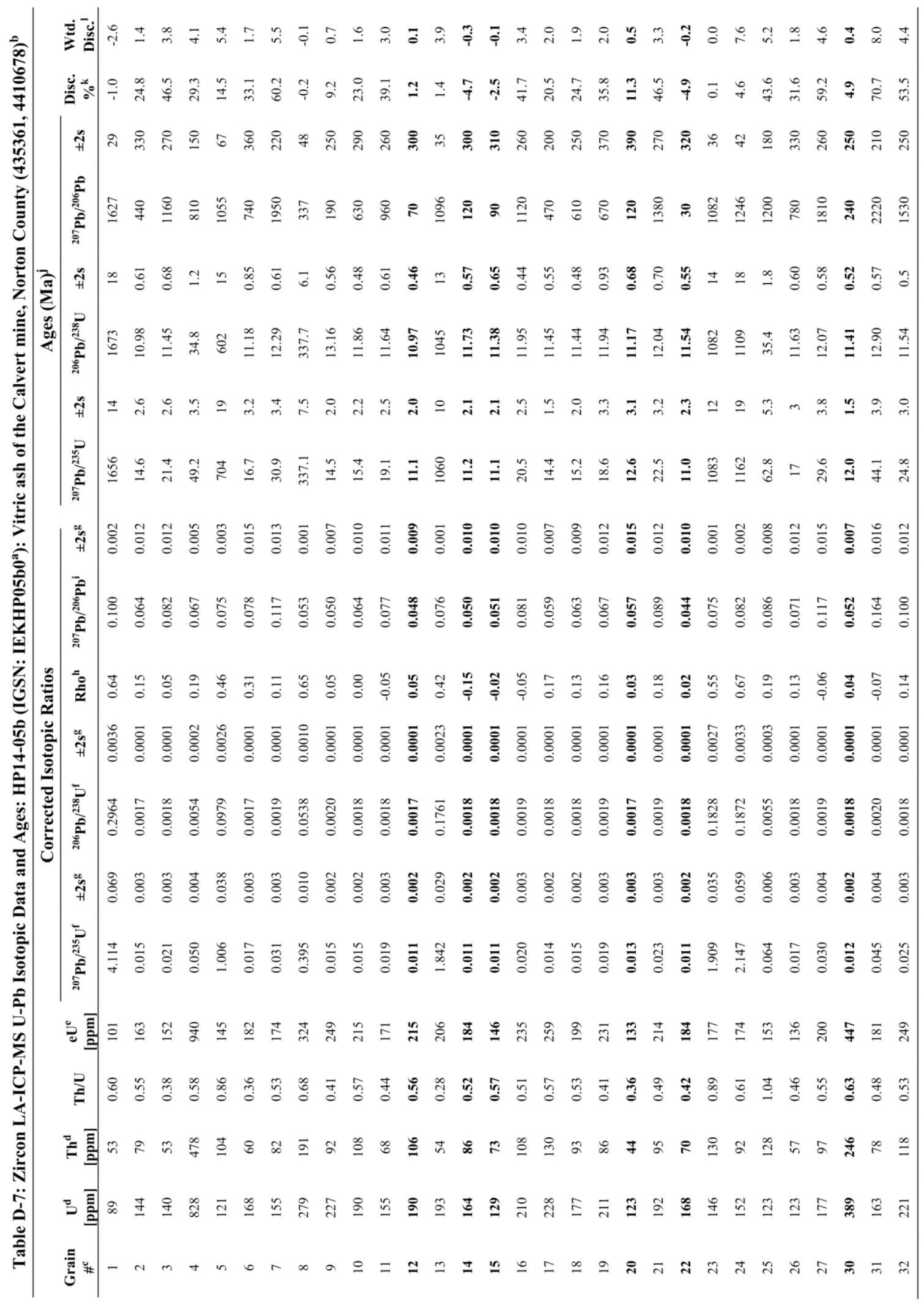




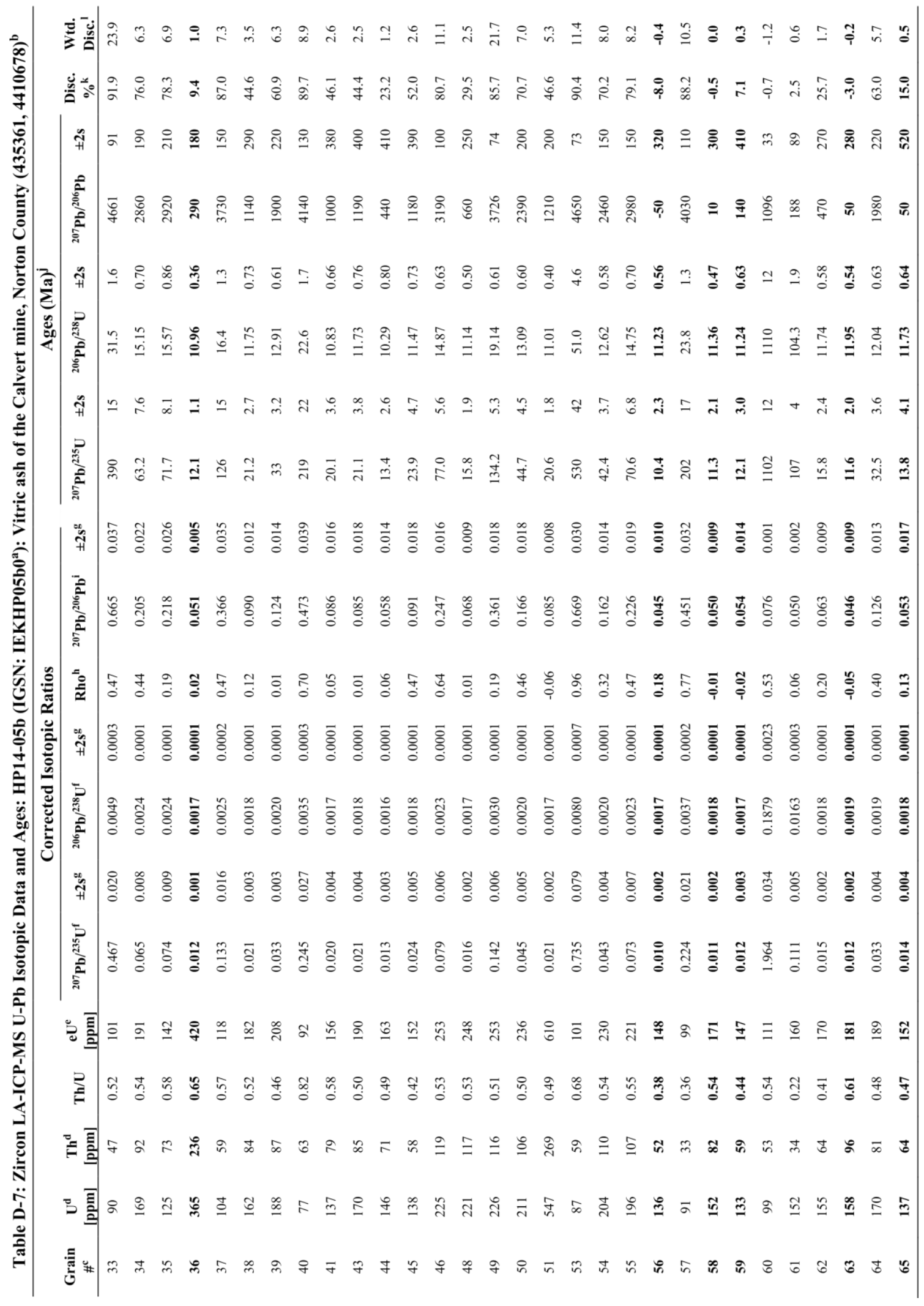




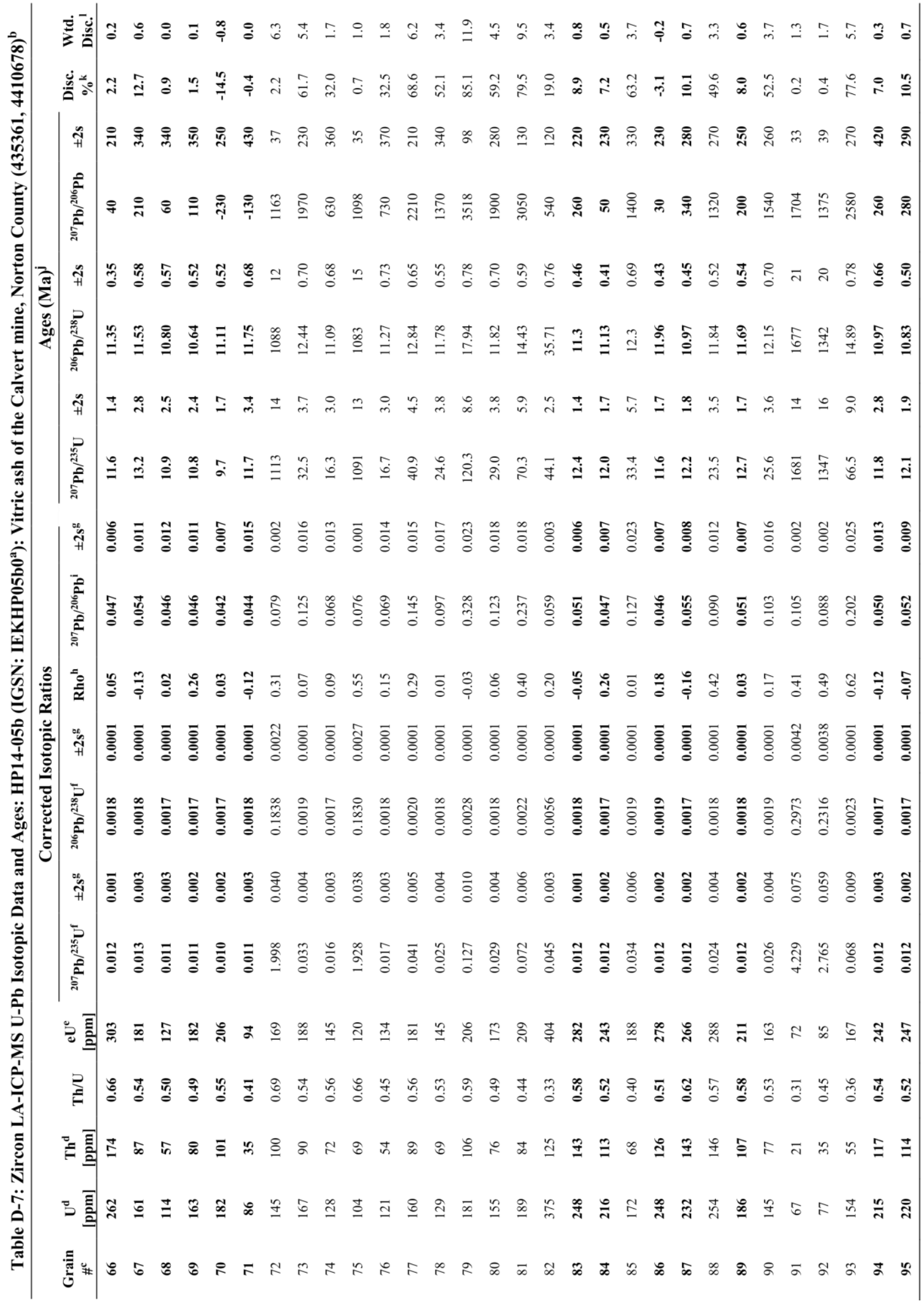




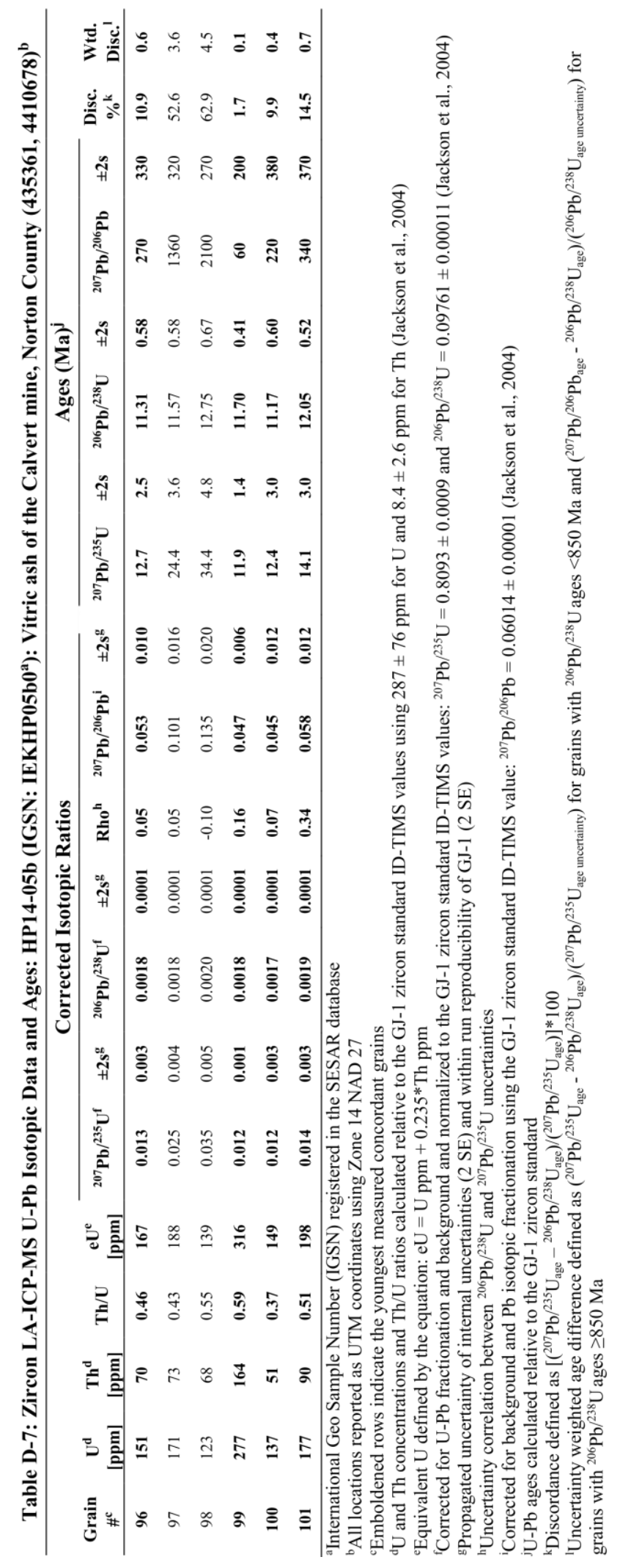




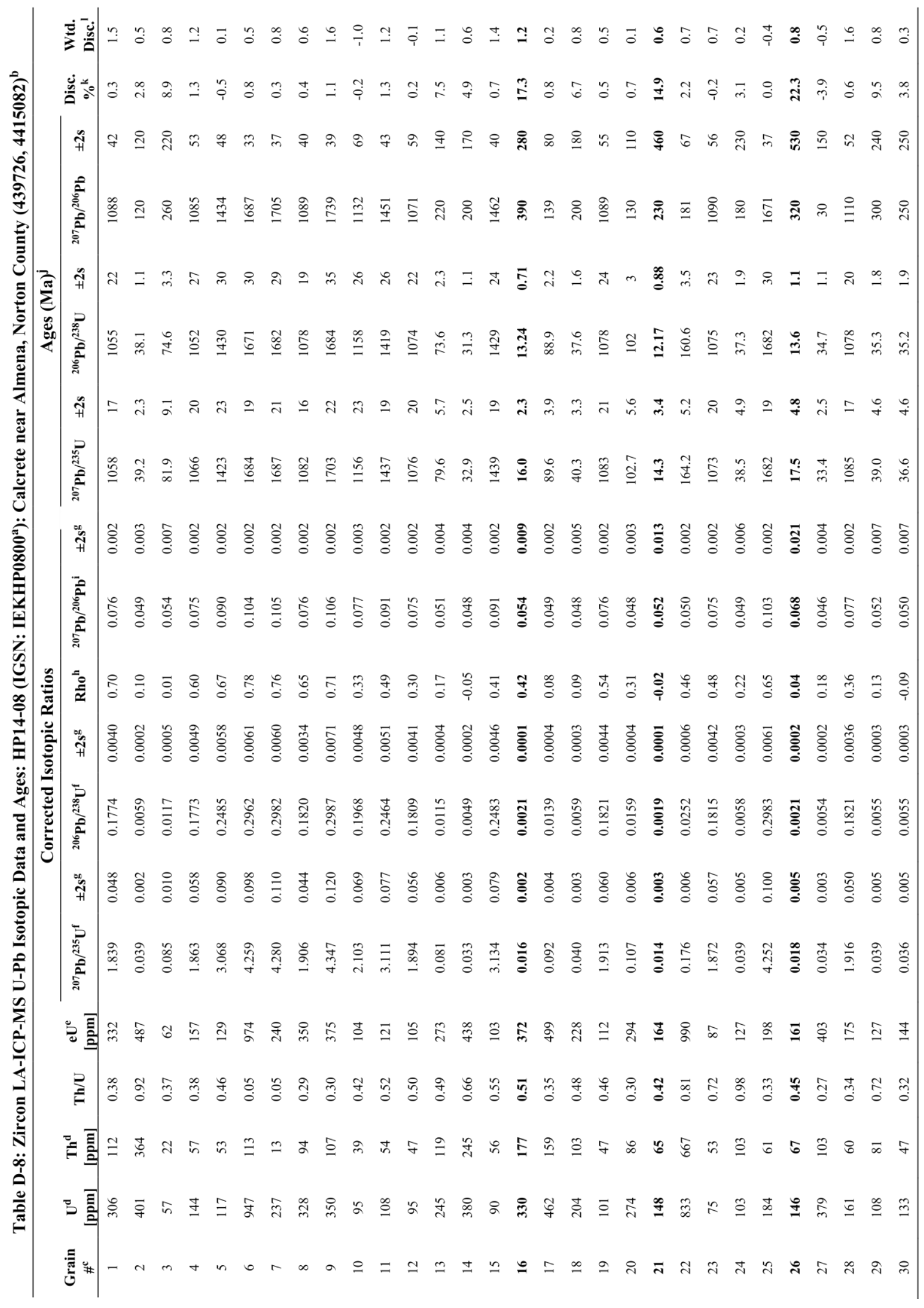




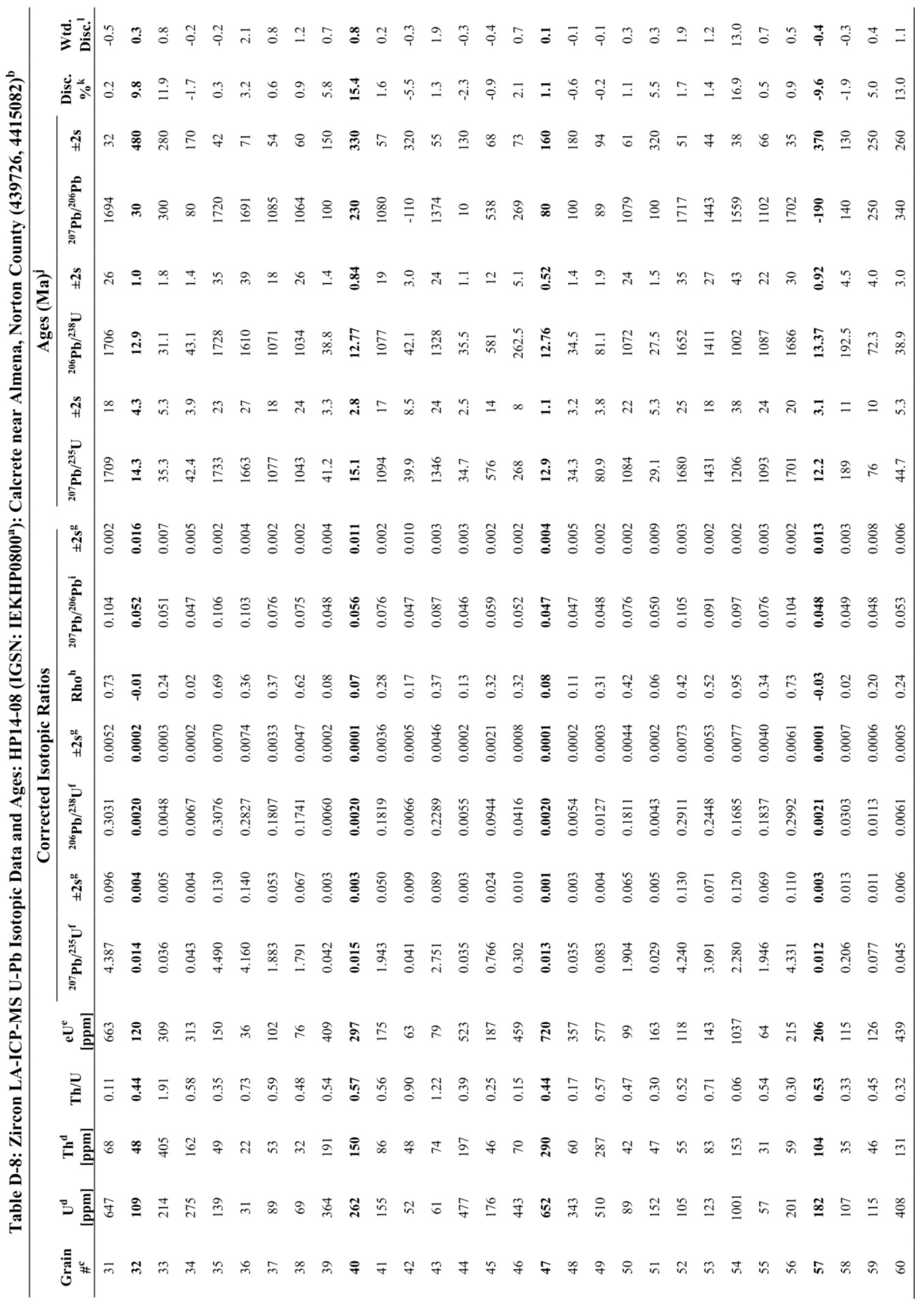




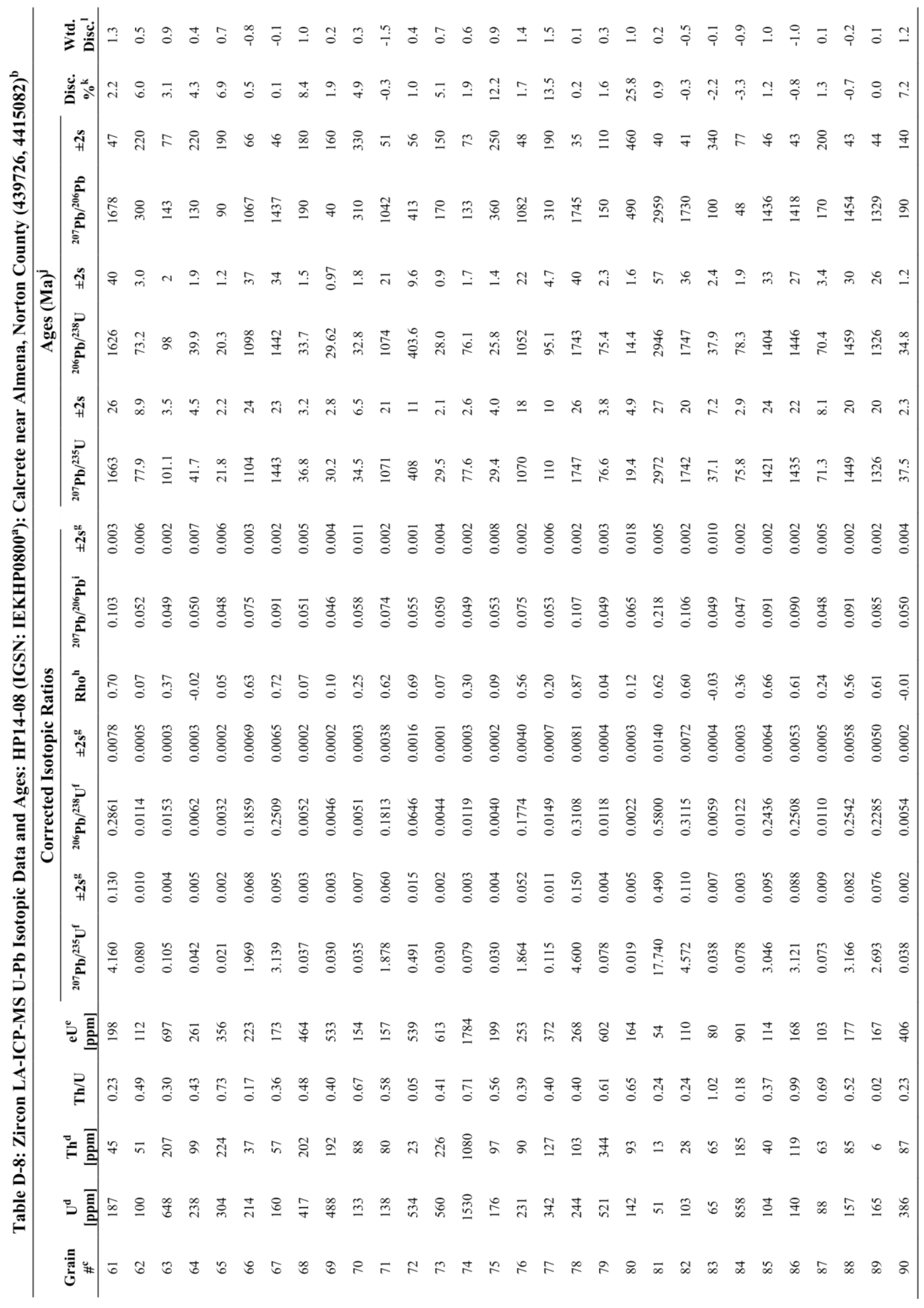




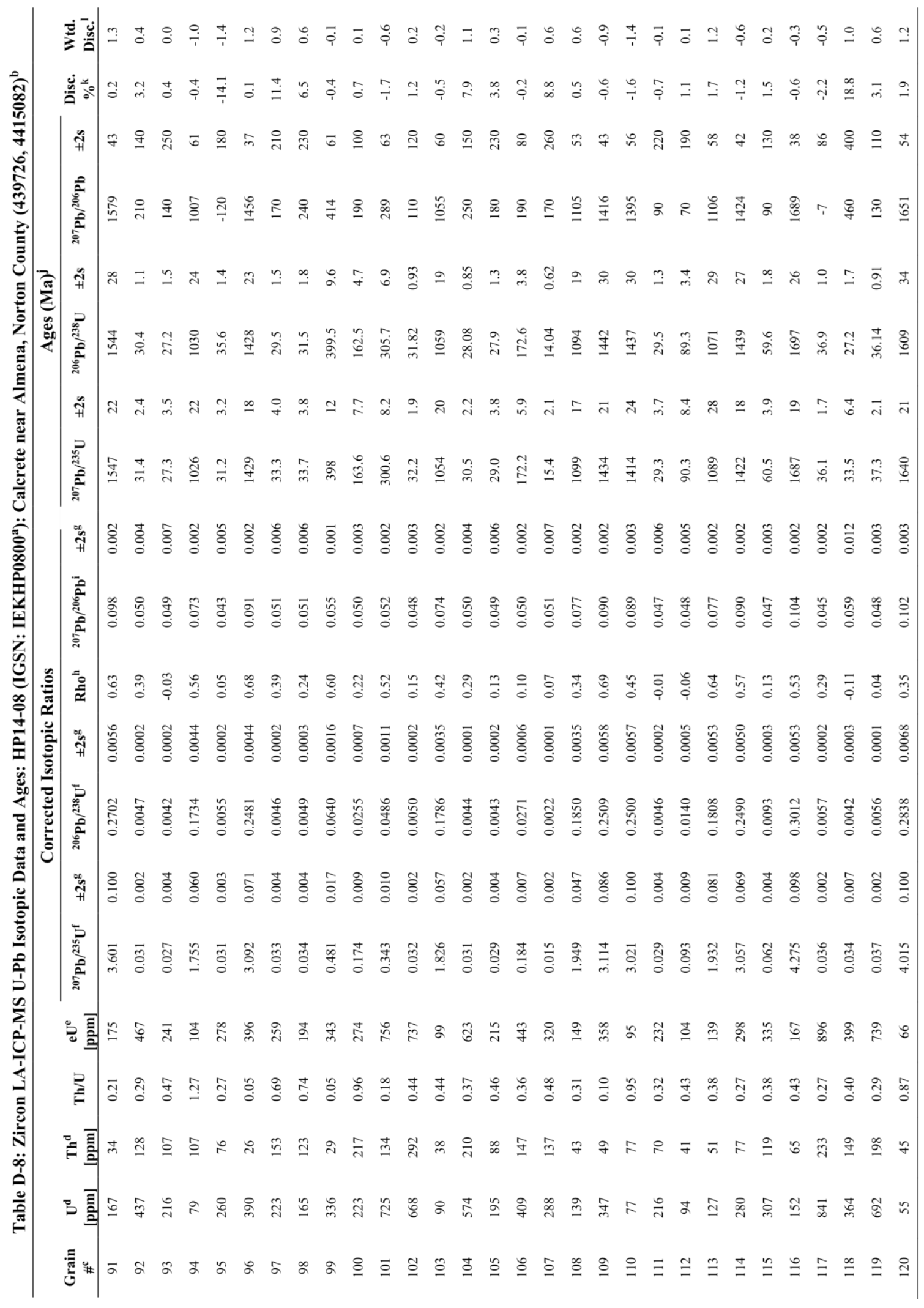




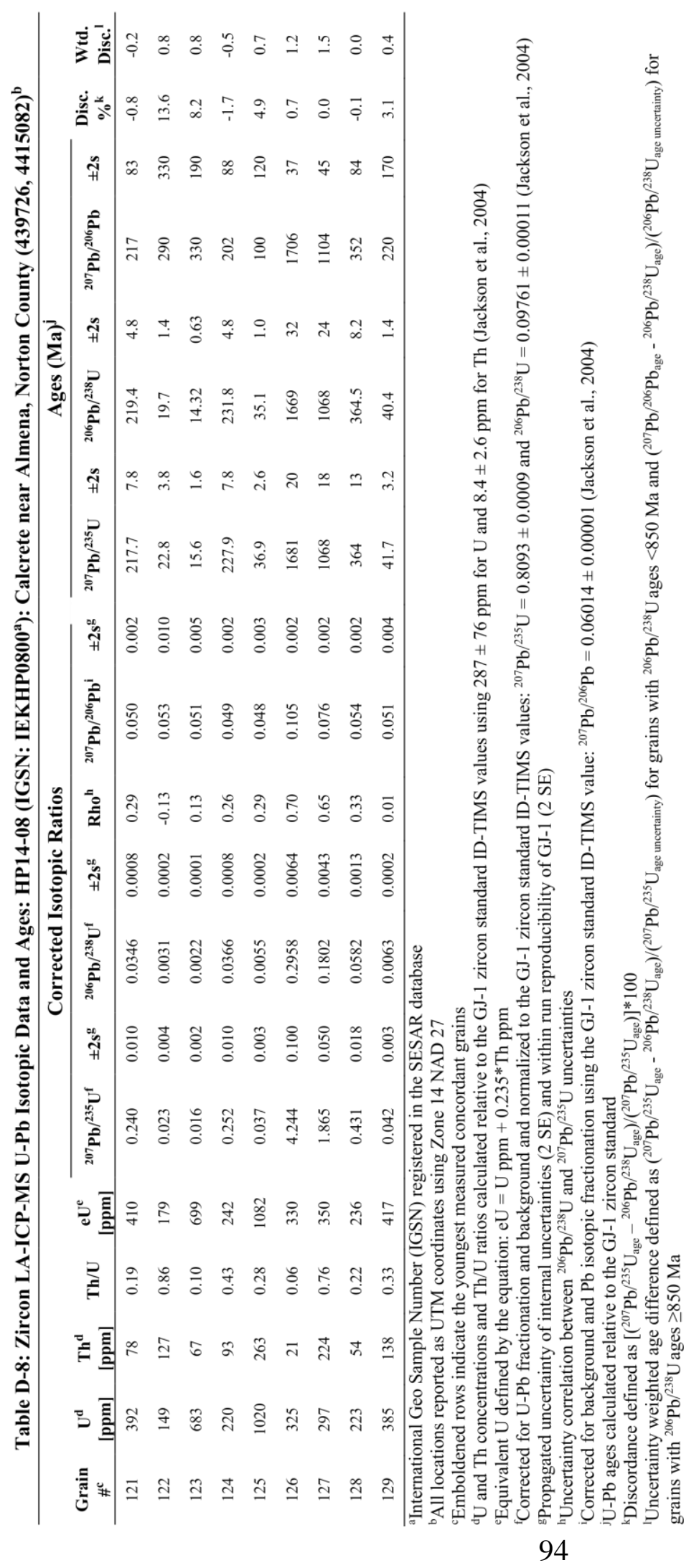

